DOE/IR/70004-1

Dist. Category UC-13

\title{
Geothermal Energy Employment and Requirements 1977-1990
}

December 1981

$$
\text { DOE/IR/70004--1 }
$$

DE82 2006001

Prepared by:

Institute of Human Resource Management

University of Utah

Salt Lake City, Utah 84112

Under Contract No. DE-AT03-77-IR70004

Prepared for:

U.S. Department of Energy

Office of Energy Research

Office of Field Operations Management

DISCLAIMER

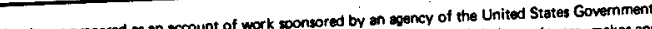

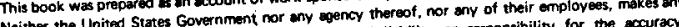

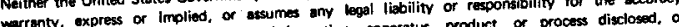

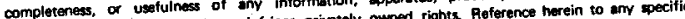

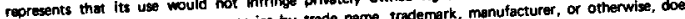

commercial product, process, or worles by

not necesssarily constitute or imply ths

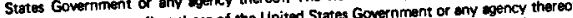

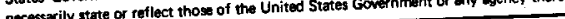





\section{DISCLAIMER}

This report was prepared as an account of work sponsored by an agency of the United States Government. Neither the United States Government nor any agency Thereof, nor any of their employees, makes any warranty, express or implied, or assumes any legal liability or responsibility for the accuracy, completeness, or usefulness of any information, apparatus, product, or process disclosed, or represents that its use would not infringe privately owned rights. Reference herein to any specific commercial product, process, or service by trade name, trademark, manufacturer, or otherwise does not necessarily constitute or imply its endorsement, recommendation, or favoring by the United States Government or any agency thereof. The views and opinions of authors expressed herein do not necessarily state or reflect those of the United States Government or any agency thereof. 


\section{DISCLAIMER}

Portions of this document may be illegible in electronic image products. Images are produced from the best available original document. 
FOREMORD

As the Nation takes steps to develop alternative energy sources, it is important to consider the possible barriers to the development and use of these sources. One of these barriers may be insufficient numbers of professional, technical and skilled workers, which could reflect a national shortage in specific occupations, an industry-wide shortage of personnel trained in the particular skills of that industry, or a geographic shortage at regional or local levels. By having information on current and estimated future personnel requirements, industrial organizations, education and training institutions and others considering initiating or deferring programs or actions affecting the supply of trained workers may have a more rational basis for their decisions.

We wish to acknowledge the assistance and support of organizations in industry, educational institutions, and goverment agencies involved in geothermal activities which provided the University of Utah with much of the basic data required for carrying out this study. 
$\cup$

$\mathcal{U}$

ง 
$\underline{\text { Page }}$

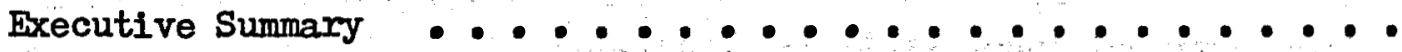
xii

Geothermal Employment .................... xi1

Current and Potential Stringencies . . . . . . . . . xili

Employment Forecast . . . . . . . . . . . - •

Technology Assessment ....................

Summarized Conclusions . . . . . . .........

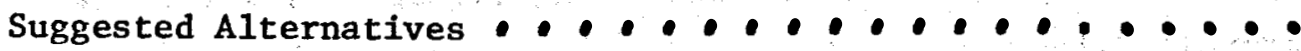

Xv

xvi

Chapter 1. Introduction and Methodology . . $\ldots \ldots \ldots$

Introduction ...........................

Methodology ........................

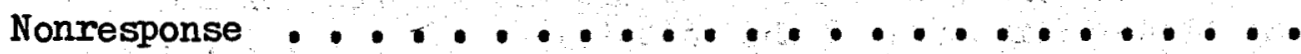

Estimate of Total Employment .................

Chapter 2. Detailed Baseline Employment Information . . . . .

Introduction $\ldots \ldots \ldots \ldots \ldots$

Results ...........................

Responses by Organizational Type .......... 10

Private Firms and Individuals ............ 12

State and Iocal Governments . . . . . . . . 13

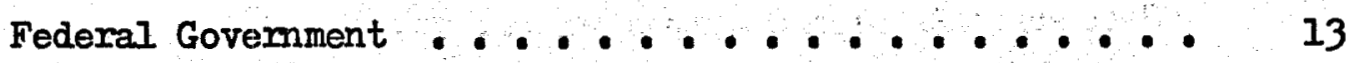

Higher Education Institutions . . . . . . . . 14

Analysis by Activities and Phases of Development . . . . 14

Distribution of Person Months by Activities and Phases . . 16

Resource Exploration and Assessment (Excluding Drilling). 16

Reservoir Design and Development (Excluding Drilling) . . 22

Vell Drilling and Drilling Services . . . . . . . 22

Plant Design and Construction............. 22

Steam Production and Transmission ........... 22 


\section{TABLE OF CONTENTS (Continued)}

Page

Chapter 2. (Continued)

Space Heating .................. 22

Electrical Energy Production ............ 23

Agricultural Applications .............. 23

Nonelectrical Industrial Applications . . ..... 23

Environmental . . . . . . . . . . . . 23

Conclusions ...................... 23

Final Mail Survey .................. 24

Employment Summary .............. 25

Occupational Employment in Geothermal Activities . . . . . 27

Geographic Sites . . . . . . . . . . . . . 27

Research and Development ............. 33

Conclusion .......................... 35

Chapter 3. Current and Potential Occupational Stringencies and

the Occupational Structure of the Industry . . . . . . . 37

Introduction ............... 37

Criteria for Selection . . . . . . . . . . . . 37

Evaluation of the Personal Interview Approach . . . . . 38

Results of the Personal Interviews . . . . . . . . 39

Employment Summary ............... 39

Occupational stringencies ............ 39

Primary Problem Occupations ............. 41

Secondary Problem Occupations ............ . 43

New and Emerging Occupations ........... 44

Projection Information and Occupational Profiles . . . . . 46

Exploration and Appraisal of the Resource....... 46

Occupational Profile .................. 48

Reservoir Design and Development . . . . . . 49

Number of Wells Required to Prove Feasibility of Energy

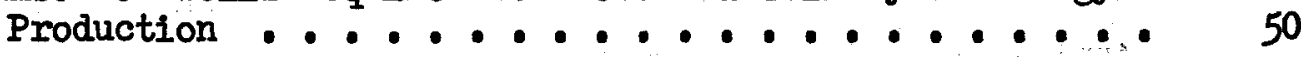

Occupational Profile for Drilling Firms . . . . . . 51

Manpower Requirements for the Reservoir Feed System . • 52 
Chapter 3. (Continued)

Construction of Power Plants .......... 54

Operation and Maintenance of Power Plants ...... 54

Total Employment Trends .................. 58

Firms Involved in Research and Development ....... 60

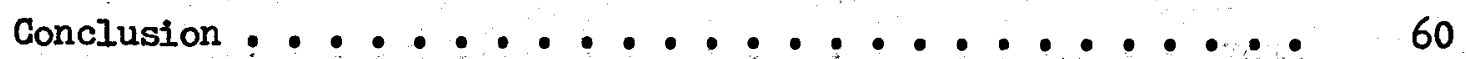

Chapter 4. Manpower Forecast . . . . . . . 63

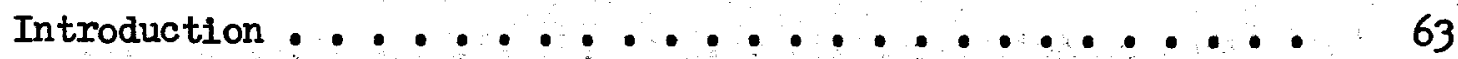

Geothermal Hectrical Energy Growth Scenario . . . . . 63

Assumptions ............................. 66

The Forecast ....................... 69

Total Manpower Requirements for 1980 Through 1985

Forecasted Growth (New Plants) . . . . . 69

Total Manpower Requirements for 1986 to 1990 Forecasted

Growth (New Plants) ............... 7

Total Manpower Requirements for 1980 to 1990 Forecasted

Growth (New Plants) ............ 7

Net Growth in Employment ................... 7

The Application of Multipliers ............ 76

The Development of an Employment Multiplier . . . . 77

Supply Considerations ................... 79

Comparison of Forecasted Geothermal Employment with Other

Energy Related Industries ............ 80

Forecast of Employment by Occupation .......... 80

Bibliography ............................. 91

Chapter 5. Technology Assessment ............. 93

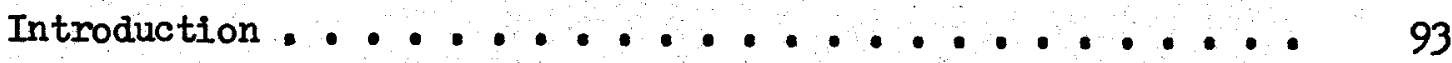

General Method of Approach .................... 94

Delphi Method .................. 95

Definition and Methodology of the Delphi Technique ... 95

Application of the Delphi Technique to the Geothermal

Industry ............... 
TABLE OF CONTENTS (Continued)

Page

Chapter 5. (Continued)

Statistical Results .............. 99

Conclusions ........................ 107

Chapter 6. Suggested Alternatives ................... Ill

Bibliography ................................ 113

Appendix A. Discussion and Definitions of the Employment Matrix - 123

Definition of Activities ................. 124

Definttion of Phases ................... 126

Appendix B. Occupational Profiles from Project Independence ... 131

Geothermal Manpower Estimates ............ 132

Appendix C. Occupation Profiles Developed From This Study .... 141

Appendix D. Manpower Forecast by Specific Occupations ..... 149 


\section{TABLE OF CONTENTS (Continued)}

\section{IIST OF TABLES}

$\underline{\text { Page }}$

Table 1. Employment Resulting Directly From Commercial

Electrical Energy Production .............. xiv

Table 2. Employment From All Other Geothermal Activities . • • . xiv

Table 3. Comparison of Initial and Follow-Up Responses by

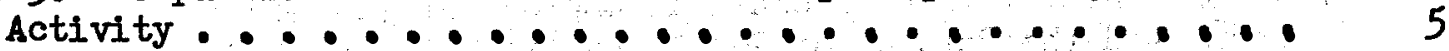

Table 4. Responses by Organizational Type . . . . . . 10

Table 5. Employment Data by Organizational Type . . . . . 12

Table 6. Employment Data by Organizational Type for Final.

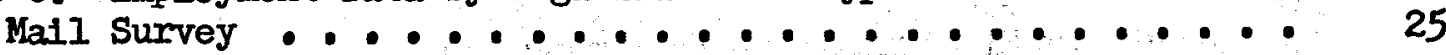

Table 7. Ratios of Geothermal to Total Employment by

Organizational Type ................ 26

Table 8. Involvement with Known Geothermal Resource

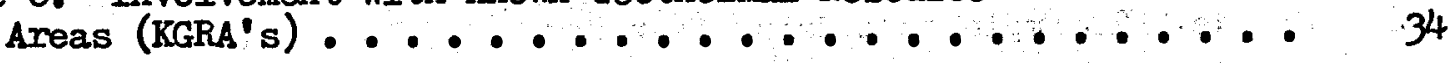

Table 9. R \& D Budget as a Percent of Total Budget . . . . . . 34

Table 10. Percent of Geothermal Workforce Engaged in R \& D . . 35

Table 11. Employment Summary . . . . . . . . . . . 40

Table 12. Occupational Profile from Project Independence

Exploration and Appraisal of the Resource . . . . . 48

Table 13. Combined list of Occupations or Occupational Groups

Involved in Resource Exploration and Appraisal ....... 49

Table 14. Occupational Profile from Project Independence . . • $\quad 51$

Table 15. Occupational Profile from Personal Interviews • • •

Table 16. Occupational Profile from Project Independence
Construction of Gathering System

Table 17. Occupational Profile from Project Independence Operation and Maintenance of Gathering System . . . . 53

Table 18. Occupational Profile from Project Independence Design and Construction of Power Plant ............ 55

Table 19. Occupational Profile for Construction Activities for Commercial Power Plants (Approximately $50 \mathrm{MW}_{e}$ ) as Drawn from Personal Interviews ....................

Table 20. Occupational Profile from Project Independence Operation and Maintenance of Power Plants ........ 


\section{TABLE OF CONTENTS (Continued)}

\section{LIST OF TABLES}

Table 21. Occupational Profile for the Operation and

Maintenance of a $10 \mathrm{MW}_{\mathrm{e}}$ Demonstration Plant . . . . . .

$\underline{\text { Page }}$

Table 22. Occupational Profile for Operation and Maintenance

of a Commercial Power Plant . . . . . . . . 58

Table 23. Estimate of Total Geothermal Employment (Number of Persons) And the Percent of Geothermal to Total Employment, By Year ..........................

Table 24. Total Number of Persons Employed in Geothermal

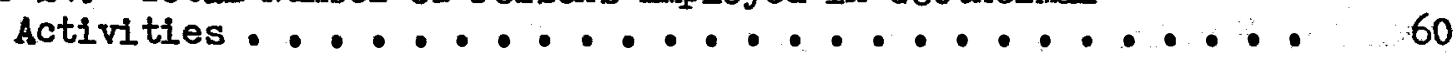

Table 25. Growth in Electrical Energy Production . . . . ... 73

Table 26. Existing Manpower Stock (In Person Months) for 1979 • . 74

Table 27. Net Employment Gains in Person Months . . . . . . 75

Table 28. Net FTE Employment Gains (New Hires) . . . . . . 76

Table 29. Total Industry Employment Gains . . . . . . . . 78

Table 30. Comparison of Forecasted Employment in Energy Related Industries .................... 81

Table 31. Resource Exploration and Assessment ........... 83

Table 32. Drilling .................... 84

Table 33. Reservoir Feed System (Constmuction) . . . . . . 85

Table 34. Reservoir Feed System (operation/maintenance) . . . 86

Table 35. Construction of Power Plants . . . . . . . . 87

Table 36. Operation and Maintenance of Power Plant . . . . . . 89

Table 37. Classification of First Round Respondents by Areas of Expertise .................. 100

Table 38. Classification of Second Round Respondents by Areas

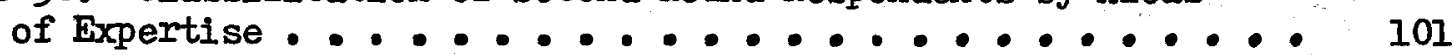

Table 39. Geothermal Manpower Project/Human Resources Institute

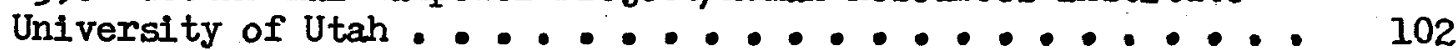


TABLE OF CONTENTS (Continued)

LIST OF FIGURES

Page

Flgure 1. Matrix of Activities and Phases of Development . . . :

Figure 2. Distribution of Person Months for All Organizations Combined ..........................

Figure 3. Distribution of Person Months for Private Firms and Individuals ........................

Figure 4. Distribution of Person Months for State and Iocal

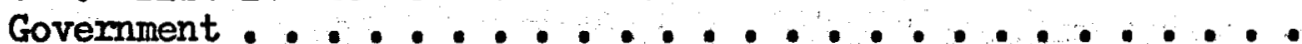

Figure 5. Distribution of Person Months for the Federal

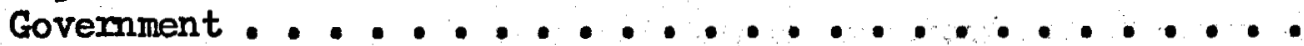

Figure 6. Distribution of Person Months for Educational Institutions .........................

Figure 7. Total Person Months for All Organizational Types . • • 28

Figure 8. Total Person Months for Private Sector . . . . . . 29

Flgure 9. Total Person Months for State and Iocal Government . . 30

Figure 10. Total Person Months for Federal Government . . . . 31

Figure 11. Total Person Months for Educational Institutions . . 32

Figure 12. Estimates of $\mathrm{MW}_{e}$ to be Generated from Geothermal Resources ....................... 


\section{EXECUTIVE SUMMARY}

In order to develop a more complete picture of the magnitude of manpower involvement in and manpower needs of industries associated with energy production, the Department of Energy has funded a number of manpower assessment projects. The Human Resources Institute at the University of Utah was requested by the Division of Labor Affairs and Manpower Assessment, office of Education, Business, and Labor Affairs -- Department of Energy to conduct this manpower assessment of the geothermal industry. The specific purposes of this project were to:

(1) derive a base line estimate of the manpower involved in geothermal activities,

(2). determine if there is any current or impending likelihood of skill shortages,

(3) forecast future employment in the geothermal industry,

(4) conduct a technology assessment to ascertain the possibilities of some sudden breakthrough, and

(5) suggest alternatives commensurate with the findings that might assist in meeting manpower requirements.

The following are the summarized findings of the study.

\section{Geothermal Employment}

1. A total of 40,082 person months of employment were estimated on the basis of mail surveys and personal interviews to have been generated in geothermal activities during 1977. Since many persons worked part of the year in geothermal activities and part in other activities, this employment involved an estimated equivalent of 3,340 full-time persons.

2. The manpower was employed by an estimated 697 private firms, public agencies, and educational institutions.

3. Geothermal activity is highly concentrated, the 20 largest employers reporting accounting for 52 percent of the reported employment. 
4. Geothermal activities comprise a minor proportion of the total activities of most of the organizations involved. For private firms reporting, geothermal activities represented only 0.23 percent of their total employment.

5. Research and development accounted for 25.8 percent of all of the manpower involved in geothermal activities with resource exploration and assessment comprising approximately one-half of the $R$ \& $D$ involvement.

6. Sixty percent of all measured employment was in the scientists and engineers occupational category.

\section{Current and Potential Stringencies}

1. Employers reported difficulties in recruiting geologists, geophysicists, reservoir engineers, environmental engineers, and drill rig personnel.

2. Drill rig personnel appeared to be a problem because of the undesirable characteristics of the job, but the others were viewed as in short supply because of strong demands on a national level.

3. There did not appear to be specific occupations which were viewed as unique to the geothermal industry. The current trend is for modification of existing skills and orientation to the unique characteristics of the geothermal resource.

\section{Employment Forecast}

Forecasts of manpower requirements by occupational category are presented in the Appendix of the report and the methodology for the following forecasts (Tables 1 and 2) of total employment is presented in chapter 5.

\section{Technology Assessment}

The Delphi technique was used to anticipate technological developments of significance for manpower demand. The essential conclusion is that technology must advance in several areas in order to expand utilization of the resource, but slow, steady advance is more to be expected than any dramatic breakthrough. Therefore, it does not appear that an 
TABLE 1. EMPLOYMENT RESULTING DIRECTLY FROM COMMERCIAL ELECTRICAL ENERGY PRODUCTION

Net Employment Gains 1980-1985 (new hires)

Minimum

Maximum

11,802

32,339

Net Employment Gains 1986-1990 (new hires)

Minimum

Maximum

37,073

101,482

Net Employment Gains 1980-1990 (new hires)

Minimum

Maximum

48,875

133,821

TABLE 2. EMPIOYMENT FROM ALL OTHER GEOTHERMAI ACTIVITIES

Net Employment Gains 1980-1985 (new hires)

Minimum

Maximum

18,883

51,742

Net Employment Gains 1986-1990 (new hires)

Minimum

Maximum

59,317

162,371

Net Employment Gains 1980-1990 (new hires)

Minimum

Maximum

78,200

214,114 
unanticipated surge in manpower demand will result from rapid application of new technology.

Summarized Conclusions

Geothermal activity can be quite aptly described as an infant industry in a developed economy. It has been characterized by a large number of institutional, technological, and market uncertainties. But there is still a small segment of the activity which is well established because of long-term involvement at development sites in California (especially at The Geysers in Northern California and at Imperial Valley in Southern California), and this segment forms a rather stable core of continuous activity.

Most of the remainder of the activity occurs in firms of all sizes which are only marginally attached. Many of these firms are highly active in other energy industries, the larger ones having the capability of creating a separate geothermal staff as needed.

The attachment of manpower to the industry tends to be equally casual, much of it part-time and part-year. A drilling firm may be working on a geothermal project one month and in the petroleum industry the next. This mobility of labor and capital resources has been desirable since the activity is not yet mature enough to support on a continuing basis the large number of peripheral firms which have thus far become only marginally attached to it.

Even if geothermal activity achieves the maximum employment growth discussed in the forecast, the national impact will be minimal. However, the high concentration of scientists and engineers in the activity will make a marginal contribution to possible scarcities of this type of manpower at the national level.

Foreseen are only two areas of major long term local impact One is at The Geysers in Northern California, but development there has taken place over several years and will continue to do so in such a manner that major labor shortages are not likely. The other is at Imperial Valley in Southern California, but this development, too, will be slow and allow ample time for appropriate planning. 


\section{Suggested Alternatives,}

1. The most serious manpower problems that are likely to emerge in geothermal activities are in certain scientific and engineering occupations. Firms complain that they cannot effectively compete in the national market because they must absorb the costs of training and orienting new recruits to geothermal's special characteristics, whereas educational institutions perform that service at public expense for the oil and gas industries. The unlikely prospect for rapid and widespread exploitation of geothermal resources is the probable reason for this neglect.

Those organizations and governmental institutions which have the greatest interest in geothermal development should consider financial support to expand the number of geothermal courses offered at a few unfversities located in the western states. Demand should be sufficient to justify modest Investment, though resource-short educational institutions are unlikely to see this as a high priority. A full degree offering does not appear desirable because the basics are general to many scientific and engineering areas. By being able to draw from a pool of college trained manpower that has already been oriented to geothermal activities and has recefved spectal training courses, geothermal employers should be in a more competitive position for recruiting relative to other energy industries.

Because of the relatively small size of the geothermal development and because of the likelihood that its size relative to other energy industries will not be dramatically altered in the next ten years, no other suggestions specific to geothermal manpower are made or seen. Other problems that will emerge are associated with remote site developments. But these are of a short-term duration, and thus far the large firms involved in bringing power plants on line have demonstrated an ability to transfer skilled labor and other personnel as needed. 
2. It is Impossible to grasp the evolutionary character of a relatively new industry with a one-time study. A mail survey conducted periodically (perhaps at two or three year intervals) would help define the changing nature of the activity and the manpower structure which consequently evolves. This could be done at minimal cost since the information base is now well established.

3. A more general approach to a rationalized manpower information system for the energy industries would involve development historles of the several energy industries. Coal, oil, gas, nuclear, geothermal, and solar range from the well established to the novel. Occupational structure in these industries could be examined at various stages of development in order to determine common trends. With the numerous studies that have been done over the years sufficient documentation probably already exists for such an effort, which should be a significant step forward in developing a conceptual framework for future manpower research. It should also be helpful in foreseeing changes which empirically oriented studies do not anticipate. Finally, decision makers could draw upon a synthesis of past studies in order to more accurately define areas of needed research and to develop a general manpower information system. 
Chapter 1

INTRODUCTION AND METHODOLOGY

Introduction

Increased emphasis on the development of alternative energy systems in the United States has led to the investigation of a number of related problems. This report is directed at assessing the manpower needs of the geothermal industry. The specific objectives were to:

(1) derive a base line estimate of the manpower involved in geothermal activities,

(2) determine if there is any current or impending likelihood of skill shortages,

(3) forecast future employment in the geothermal industry,

(4) conduct a technology assessment to ascertain the possibilities of some sudden breakthrough, and

(5) suggest alternatives commensurate with the findings.

Since no previous research had been undertaken to evaluate these issues, there is no substantial evidence with which the results of this report can be compared. However, it is hoped that this first effort will serve as a useful contribution for future research designed to increase our understanding of current and future problems of the geothermal industry. The remainder of this chapter presents the methodology for fulfilling the objectives mentioned above. Chapters two through five discuss in detail the results of the pursuit of those objectives. Finally, chapter six, summarizes the alternatives suggested, based upon the findings of this study.

\section{Methodology}

The first procedural objective of this study was to identify all public and private organizations which were potentially involved in geothermal activities during 1977. This constituted the universe to which the mail survey was directed. The sources utilized to construct the mailing 
lists were mainly governmental and geothermal organizations. These included organizations which had been represented at conferences or had inquired concerning geothermal policies, programs, activities, or potential and were not necessarily directly involved in geothermal activities. Thus, the mailing list contained the potential for a considerable overestimate of the universe, and the first round of the mail survey was designed to identify those who were or were not appropriately part of that universe.

A total of 1,527 organizations comprised the original list of those with some interest or involvement, no matter how peripheral. Each of these organizations was sent a questionnaire which asked whether or not they employed people in geothermal activities in 1977 and requested general manpower information by type of geothermal activity, an appropriate contact person if the organization was willing to participate further in the study, and a list of subcontractors which were engaged in geothermal activities. All organizations which did not respond to the initial mailing received a follow-up mailing. Of the total number of organizations not responding to either mailing, approximately half were selected for a telephone survey to determine reasons for nonresponse and to attempt to obtain the necessary inf ormation.

The organizations which provided manpower estimates and indicated a willingness to participate further in the study were divided into two groups. The first group was personally interviewed in an effort to obtain comprehensive information necessary to construct a forecasting model, to define the occupational structure in various phases of geothermal development, and to determine if there were current or potential scarcities of labor which could be identified by specific occupational categories.

Only firms in the private sector were selected for the personal interview phase since private efforts are assumed to be the key to continued geothermal development. Two other criteria were of major importance. One was that the firms should be representative of the several geothermal activities which had been identified. The second was that only the large employers would be interviewed. This last criterion was considered the best avenue of approach for the following reasons.

1. Research had indicated that a few large firms formed the core of what could be defined as a geothermal "Industry," and these firms are the impetus behind the major current 
and projected geothermal projects in the United States.

Therefore, it was imperative that as many of these firms as possible should be interviewed.

2. The indications are that firms involved in geothermal development are not randomly distributed geographically, or in terms of magnitude of involvement in geothermal activities in relation to human resources or other types of resources. Therefore, a random selection of participants for the personal interview survey would in all likelihood have produced considerably less useful information in terms of quantity and quality.

3. Direct contact with industry participants, qualified observers of geothermal activities, previous studies, and the surveyor's own research led to the conclusion that the prime actors in geothermal development are readily identified. This is true not only because of the relatively small number of firms involved in geothermal activities but also because the major developers (with a few exceptions) are highly visible and highly concentrated in western states, particularly in Califormia.

4. Even though the personal interviews covered only 35 firms, they represented a large proportion, as only 307 firms provided data in the initial phase of the mail survey. A best estimate is that it is not likely that more than 400 firms are directly involved in the industry. Therefore, the 35 firms interviewed, though determined in number by avallability of resources rather than by sampling design, were not an insignificant sample, representing nearly 10 percent of the firms and an estimated 34 percent of total measured employment in the private sector. The second group of respondents from the initial mail survey received a final survey primarily designed to obtain information in broad occupational categories by geothermal activity. The major purpose of this second phase of the mail survey was to measure the concentration of manpower in these occupational categories in order to determine if these findings reinforced or weakened conclusions reached in other parts of the study.

Since geothermal activities require relatively novel techniques of production and continued geothermal development will depend heavily on technological advances, a technology assessment using the Delphi technique 
was conducted to determine the likelihood of dramatic technological breakthroughs. The results allowed a better interpretation of the probable path of growth of geothermal activities.

Finally, in order to develop a forecasting model, a hypothetical power plant was constructed with attendant manpower requirements. However, these requirements were based on the findings from the personal interview phase of the study which thus provided an empirical basis for the forecast.

\section{Nonresponse}

In order to qualify the estimate of employment for the baseline year and to develop more confidence in the measured employment, it is necessary to address the problem of nonresponse. The following discussion describes how the problem was handled in the context of this study.

Only 489 of the 1,527 organizations comprising the original mailing lists responded that they had been involved in geothermal activities in 1977. A total of 363 responded that they had not been so involved. An additional 200 could not be contacted by either mail or telephone, apparently being no longer in existence. This left an apparent nonresponse of 475 .

A determination was made to call every other organization on the Iist of nonrespondents; however, telephone numbers were not obtainable for 65 organizations. The ultimate result was 202 calls with the following outcome:

$$
\begin{aligned}
& 202 \text {. Contacted by telephone } \\
& 58(28.7 \%) \text { Responding that they were not in the industry } \\
& 32 \text { (15.8\%) Providing the requested manpower data } \\
& 112 \text { (55.4\%) Not willing to participate, not returning } \\
& \text { telephone messages, etc. }
\end{aligned}
$$

This brought the total of organizations engaged in geothermal activities to 521 and those on the original list not so engaged to 621, with 385 in doubt, 273 of which were not included in the telephone survey, and 112 of which refused to respond. Thus the total response rate for the potential universe (those engaged plus those unknown) was 57.5 percent. If the 385 not contacted were distributed between engaged and non-engaged in geothermal activities in the same ratio as those who responded to the various mail and telephone surveys, the total universe of geothermal 
organizations would comprise 697 and the response rate would be 74.7 percent.

Of the 521 responding, 448 provided usable manpower data. Thus the data base for much of this report is constructed on usable returns from 64.3 percent of the apparent universe.

The total person months of geothermal employment generated by the size of the 176 organizations likely to have had geothermal activity but not responding to the surveys can be estimated from three sources.

First, the respondents from the initial mailing can be compared with the respondents to the follow-up mailing. Given the matrix format utilized in designating involvement of manpower by various activities and phases, the numerous ways of cross-classifying the results precludes discussion in every area. However, the distribution of the two groups can be summarized by examining the respective sums of person months by activities. Table 3 illustrates these results.

TABLE 3. COMPARISON OF INITIAL AND FOLLOW-UP RESPONSES BY ACTIVITY

(Employment by Person-months)

\begin{tabular}{lcc}
\hline \hline & $\begin{array}{c}\text { Initial Response } \\
\text { (306 providing data) }\end{array}$ & $\begin{array}{c}\text { Follow-up Response } \\
(110 \text { providing data) }\end{array}$ \\
\hline Disassociated a & 3,680 & 1,560 \\
Resource exploration \& appraisal & 8,351 & 1,594 \\
Reservolr design \& development & 2,062 & 476 \\
Well drilling \& drilling services & 3,990 & 1,769 \\
Plant design \& construction & 1,496 & 1,461 \\
Steam production \& transmission & 1,471 & 101 \\
Space heating & 238 & 81 \\
Electrical energy production & 595 & 1,435 \\
Agricultural applications & 342 & 271 \\
Nonelectric industrial applications & 61 & 0 \\
Environmental & 1,433 & 935 \\
& 23,719 & 2,083 \\
\hline
\end{tabular}

This category means that the quantity of person months given was not specified by type of activity. 
Note that the number of respondents in the follow-up category is approximately $1 / 3$ of the number in the initial response category. If the two groups are from the same population, one would expect at least a loose correspondence of the same proportions in person months in each activity or in all activities combined. The table reveals that there are two important activities which are serious exceptions -- plant design and construction and electrical energy production. Also, the means for each response group for the total of all activities are 77.5 for the initial and 82.6 for the follow-up, the opposite result required to fortify the conclusion that the nonrespondents do not contain serious omissions of data.

However, viewed another way the above illustration points out the controlling nature of a few large firms. Examination of the individual responses reveals that one organization with a total of 2,400 person months happened to fall in the follow-up category. If this organization had responded to the initial mailing, the ratios would have been more favorable -i.e., means of 85.4 for the initial and 60.8 for the follow-up mailing. The methodological point is that the unique characteristics and restrictive size of the geothermal industry do not lend themselves to a strictly quantitative approach. In other words, in this case the assumptions underlying random processes may be open to serious question. This is one of the main reasons why we elected to survey the entire potential universe rather than rely on any type of random sampling procedure.

The second body of evidence relating to the size of firms in the nonresponse category comes from the telephone survey. In this case the average number of person months was $35 .^{1}$ This is certainly a dramatic drop in contrast to the means calculated from the initial and follow-up mail responses. It indicates that the nonrespondents maintain a more marginal attachment in terms of manpower devoted to geothermal activities. Therefore, it seems reasonable to assume that the mean calculated from the telephone survey is most representative of the total number of nonrespondents which are assumed active in geothermal activities.

The third qualification of the size of the nonrespondents comes from the first-hand experience of long-term efforts in identifying

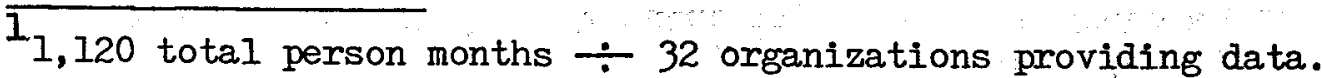


organizations in the industry and in continuously seeking information about geothermal activities. Given the relatively small number of organizations associated with geothermal development, it is possible to become quite familiar with the industry structure and its participants. This knowledge reinforces the confidence in the measurements and estimates contained in this report. There are, however, reservations in the following areas:

1. Less confidence is expressed in the results pertaining to the government sector (federal, state, and local) because of the pyramiding structures of organization which are likely to lead to some cases of double counting and omissions.

2. Involvement of educational institutions is difficult to measure because of the nature of research contracts and the many different types of scientific and engineering expertise required to support basic and applied research. The distribution of such personnel may vary considerably in different universities, thus making it quite difficult to identify the appropriate department or research institution to which inquiries should be addressed.

3. The surveyor's greatest familiarity is with the private sector. Therefore, the Important firms which failed to respond to inquiries became obvious. It is thought that only one large employer was not responsive to any type of contact. There were other smaller employers which were also in this category.

\section{Estimate of Total Employment}

This estimate is derived from combining the total measured employment $(33,922$ person months) with the additional employment estimated to be generated by the group of nonrespondents. The latter estimate is derived from the following procedure.

As shown in the discussion above, the number of potential nonrespondents estimated as likely to be involved in geothermal activities but not responding was 176 . The telephone survey revealed that the mean 
employment of the organizations providing data was 35 person months. Assuming that this mean is most representative of this group of nonrespondents the procedure is simply to multiply the number of nonresponding (176) by the average number of person months for responding organizations to obtain 6,160 person months. This is the estimate of the additional employment which is generated in the nonresponse category, and when it is added to the total measured employment, the estimate of total employment in geothermal activities is 40,082 person months. 
Chapter 2

DETAILED BASELINE EMPLOYMENT INFORMATION

\section{Introduction}

This phase of the study consisted of three initial mailings, a final mailing, and follow-up mallings for each category. The investigation was designed to provide the bulk of information necessary for a baseline (1977) estimate of employment in the geothermal industry with the objective of surveying all organizations (public and private) which were known to be involved or potentially involved in the geothermal industry. The bulk of the mailing list was compiled from such sources as the Geothermal Resources Council's Geothermal Registry and the Geothermal World Directory (1977/78 edition), which is published by Geothermal World Publications. Other sources were the list of the Department of Energy's geothermal related contracts, the contractors listed by organizations responding to the questionnaire, and information conveyed by personal contact with industry. participants.

Because more organizations were becoming known through these continuing efforts, three separate initial malings were necessary. These took place in February, July, and October 1978. In each case a follow-up request was made to the nonrespondents from one to two months after the first mailing.

\section{Results}

The findings in this part of the study provide the best overall picture of manpower involvement in the geothermal industry by the various types of activities. Given the large number of ways in which the data can be cross-classified, a decision was made to be selective and point out descriptively the most important and interesting comparisons. 
Responses by Organizational Type

The 1,527 questionnaires mailed and response rates are categorized by the type of organization in Table 4. Note that all nonprofit or other types of organizations that could not be strictly categorized as a government agency or educational institution were included in the private sector.

TABLE 4. RESPONSES BY ORGANIZATIONAL TYPE

\begin{tabular}{|c|c|c|c|}
\hline & Total Mailed & $\%$ of Total & Response Rate \\
\hline Private firm or individual & 1,215 & $79.6 \%$ & 53.6 \\
\hline State or local government & 88 & $5.8 \%$ & 74.2 \\
\hline Federal government & 70 & $4.6 \%$ & 70.9 \\
\hline Educational & \pm 154 & $10.0 \%$ & 65.5 \\
\hline Total & 1,527 & $100.0 \%$ & \\
\hline
\end{tabular}

There were 448 organizations which provided manpower estimates by specific activities for 1977. The range of employment by organizations engaged in geothermal activities was from 2,725 person months to one person month (all quantities greater than .5 were rounded to one). With all organizational types taken together the top twenty organizations account for 52.02 percent of all person months measured in the survey. Of these the federal government accounted for 13.48 percent of the total, educational institutions accounted for 3.31 percent of the total, and the private sector accounted for 35.23 percent of the total. The following figures lend more perspective to the degree of concentration.

Number of Organizations

21

19

8

11

30

79

280
Percent of Total Measured Manpower

$\geq 1$

$\geq .5$ and $<1$

$\geq .4$ and $<.5$

$\geq .3$ and $<.4$

$\geq .2$ and $<.3$

$\geq .1$ and $<.2$

$<.1$
Mean Employment (person months)

859.8

216.2

154.6

116.9

84.4

44.7

10.6 
As was pointed out earlier, there was considerable difficulty in avoiding duplication of data from the same organization at different addresses or even different organizations at the same address. The basic criterion was to count different mailing addresses as different organizations, but this was considerably modified as various cases warranted. This method appears to have worked best for the category of private firm or individual. 2

It was also possible to determine that most of the educational institutions responding were various academic departments or special research institutions. Therefore, the number of organizations indicated in this category will also tend to be a slight overstatement since more than one department or research institution could have been surveyed from a single university or other institute of higher education. Also, the survey in this area was dominated by colleges with four year degree programs and graduate programs.

The complex and varied structures of government at the state and local levels introduces a greater degree of uncertainty as to whether or not duplication of data was successfully avoided. However, when questions arose, an attempt was made to ascertain the right answers by recontacting the respondents by telephone.

A problem in surveying organizations in the federal government concermed the level of aggregation. For example, whenever it appeared that a large number of field offices were being surveyed (e.g., for the U.S.G.S.), an attempt was made to go to the highest level in the organization that would have the needed information centrally located for all its field offices. Table 5 demonstrates that this method of aggregation considerably increases the "size" of the government organizations which were being surveyed.

Despite the uncertainties introduced in the above discussion, it appears that uncertainty is minimized in the most important area, the private sector. However, the manpower data provide only a static picture of what appears to be a rather dynamic industry in terms of entry and exit of firms. Although hard evidence is sparse (as indicated in the personal interview phase and correspondence with past and potential industry

The term, private individual, in most cases means a consultant. 
TABLE 5. EMPLOYMENT DATA BY ORGANIZATIONAL TYPE

\begin{tabular}{lccc}
\hline \hline & $\begin{array}{c}\text { Number of Organi- } \\
\text { zations Providing } \\
\text { Employment Data }\end{array}$ & $\begin{array}{c}\text { Mean } \\
\text { (person }\end{array}$ & $\begin{array}{c}\text { Median } \\
\text { (person }\end{array}$ \\
months)
\end{tabular}

participants), it seems that the profit incentive coupled with a perception of industry stability (which in turn was dependent on solutions to institutional problems) is the driving force behind this movement.

Private Firms and Individuals

The range of employment in the private sector was from 2,400 person months to one person month (all quantities greater than 0,5 were rounded to 1.0). In this category the top twenty firms accounted for 57.18 percent of employment in the private sector, and just over half the employment, 50.19 percent, is derived from only eighteen firms. The complete distribution in the private sector is as follows.

\begin{tabular}{ccc}
$\begin{array}{c}\text { Number of } \\
\text { Firms }\end{array}$ & $\begin{array}{c}\text { Percent of Manpower in } \\
\text { the Private Sector }\end{array}$ & $\begin{array}{c}\text { Mean Employment } \\
\text { (person months) }\end{array}$ \\
\cline { 1 - 2 } 20 & $\geq 1$ & 673.3 \\
22 & $\geq .5$ and $<1$ & 159.2 \\
9 & $\geq .4$ and $<.5$ & 101.4 \\
17 & $\geq .3$ and $<.4$ & 79.3 \\
21 & $\geq .2$ and $<.3$ & 55.3 \\
53 & $\geq .1$ and $<.2$ & 33.7 \\
165 & $<.1$ & 7.3
\end{tabular}


Of the 307 firms providing estimates, 114 have 12 person months or less (i.e., the full-time equivalent of one person per year or less). This in part illustrates the low degree of attachment of many firms and individuals to the industry. Many of the largest employers also are not engaged in the industry as a primary activity but have created separate geothermal departments which in many cases represent only a small portion of the firm's total employment.

\section{State and Local Governments}

The 39 organizations responding in this category were concentrated in the westerm states. Because of the lack of uniformity of government structure at these levels, especially in the leasing, environmental, and regulatory activities, it is probable that the survey did not include some agencies. It was attempted to survey all agencies that could be directly identified with geothermal activities. However, to have attempted to trace all government organizations that are indirectly involved in the Industry would itself probably have consumed most of the survey resources.

The range of employment in this area was from 82 person months to one person month (all quantities greater than 0,5 were rounded to 1,0 ). In this category the seven largest agencies accounted for 54.31 percent of the geothermal related employment. A more thorough distribution is as follows.

Number of

Agencies

25

8

0

3

1

2

0
Percent of Manpower in

State \& Local Government

$\geq 1$

$\geq .5$ and $<1$

$\geq .4$ and $<.5$

$\geq .3$ and $<.4$

$\geq .2$ and $<.1$

$\geq .1$ and $<.2$

$<.1$
Mean Employment

(person months)

29.5

5.6

0.0

2.7

2.0

1.0

0.0

Federal Government

of the 33 federal government organizations responding, one accounted for 47.84 percent of the employment measured in the survey. There were 
seven with greater than one percent employment in this sector, and the cumulative total for these eight respondents was 90.96 percent. The following is a more complete distribution.

Number of Agencies

$$
7
$$

0

1.

4

4

6
Percent of Manpower in Federal Government

$$
\begin{aligned}
& \geq 1 \\
& \geq .5 \text { and }<1 \\
& \geq .4 \text { and }<.5 \\
& \geq .3 \text { and }<.4 \\
& \geq .2 \text { and }<.3 \\
& \geq .1 \text { and }<.2 \\
& <.1
\end{aligned}
$$

Mean Employment

(person months)

$$
\begin{array}{r}
740.1 \\
41.0 \\
0.0 \\
20.0 \\
13.3 \\
6.3 \\
2.5
\end{array}
$$

Higher Education Institutions

A total of 69 colleges provided estimates for the survey. Over half ( 54.0 percent) of the total educational manpower is attributed to the seven largest respondents. The final distribution is as follows.

Number of Colleges

$$
\begin{array}{r}
24 \\
16 \\
1 \\
8 \\
5 \\
8 \\
7
\end{array}
$$

Percent of Manpower in Educational Institutions

$$
\begin{aligned}
& \geq 1 \\
& \geq .5 \text { and }<1 \\
& \geq .4 \text { and }<.5 \\
& \geq .3 \text { and }<.4 \\
& \geq .2 \text { and }<.3 \\
& \geq .1 \text { and }<.2 \\
& <.1
\end{aligned}
$$

Mean Employment (person months)

135.8

44.3

18.0

11.4

8.2

5.0

2.1

Analysis by Activities and Phases of Development

The first initial mailing asked organizations to identify their manpower involvement by one (or more) of seven general activities or to list an activity if none of the others were appropriate. In addition, under the general activities the organizations were asked to list subcategories of specialization. This approach led to a large number of varied responses, which were then condensed into more rational categories. The result is shown on the matrix on the next page (Figure I). A smaller version of this 
Figure 1

MATRIX OF ACTIVITIES AND PHASES OF DEVELOPMENT

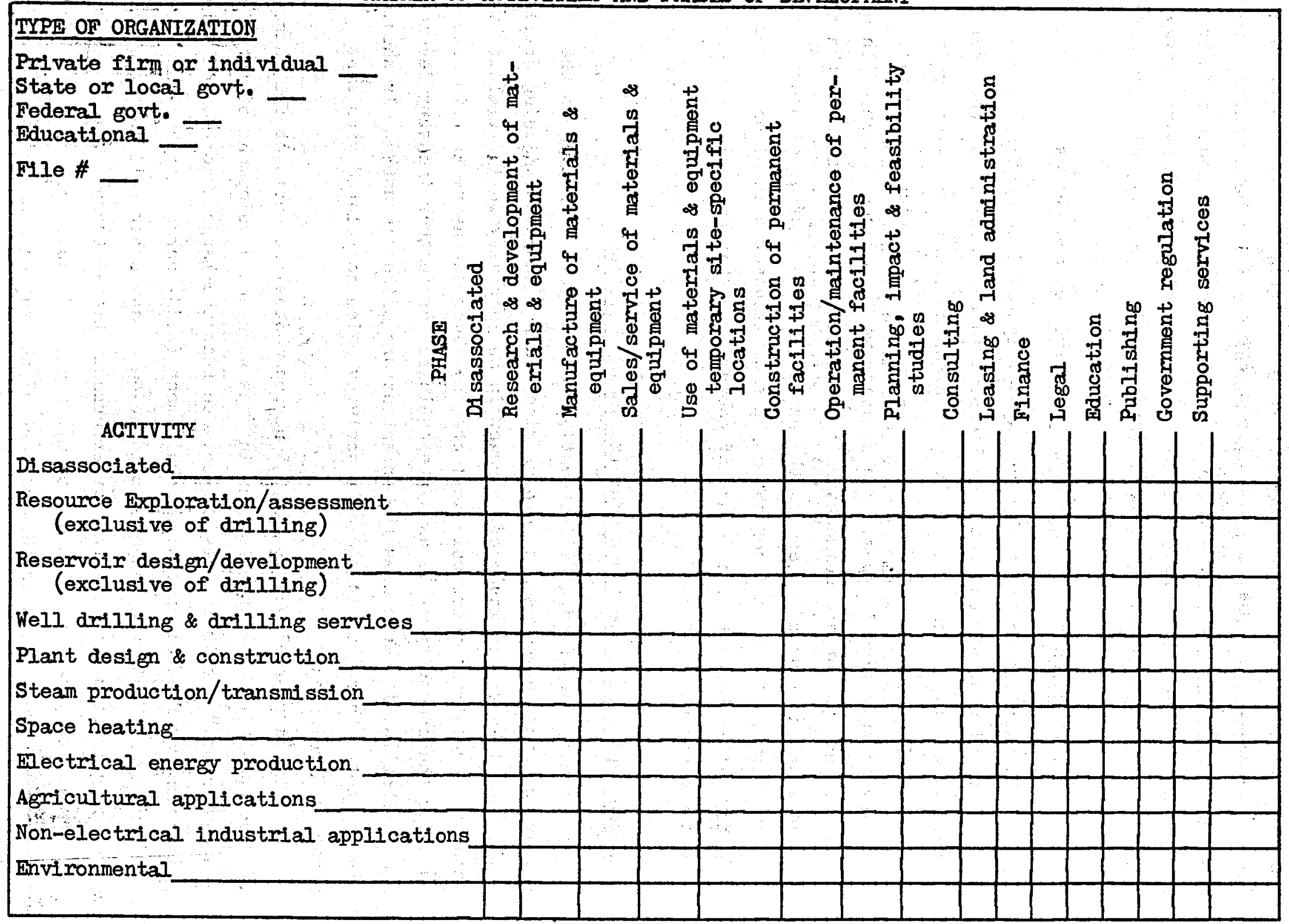


matrix was used in the two subsequent initial mailings. A discussion of the matrix and definitions of the terms used can be found in the appendix. However, note that the discussion which follows will center on geothermal activities (underlined as topic headings in the text) with appropriate responses to phases of development within given activities (see Figure 1).

\section{Distribution of Person Months by Activities and Phases}

The matrices on the following pages (Figures 2 through 6) give a descriptive view of how manpower is allocated in the industry by the four organizational types combined and by each organizational type separately. Rather than have several different discussions of the various activities and phases by organizational types, each activity will be discussed in depth only one time, and appropriate comments will be included which pertain to the type of organizations responding and to the particular phase of development. By. concentrating on the more important aspects of manpower allocation in the industry, it is hoped that a deluge of comparisons that are only of minor importance can be avoided.

\section{Resource Exploration and Assessment (Excluding Drilling)}

Nearly one-third ( 30.4 percent) of all manpower measured in the survey was engaged in resource exploration and assessment (excluding drilling), the highest allocation of manpower in any activity in 1977. This high manpower concentration not only reflects the labor intensity of this activity but also the necessity of it as a prerequisite for further industry development. That is, it emphasizes the infant nature of the industry. It should also be noted that this is the only activity which correlated with every phase of development.

The largest allocation (4,445 person months) in terms of the phase of development in this activity was in "research and development of materials and equipment." It is interesting to note that the largest portion of this allocation was Federal government employment $(2,334$ person months), and it was more than double the manpower allocation of any other cell in the matrix pertaining to this activity from other organizational types.

The temporary on-site use of materials and equipment accounted for only 1,852 person months or 18.0 percent of the entire resource exploration and assessment activity. Even combined with the phases of "construction of 


\section{Figure 2}

Distribution of Person Months for All Organizations Combined

(Data Collected Between February 1978 and February 1979)

\begin{tabular}{|c|c|c|c|c|c|c|c|c|c|c|c|c|c|c|c|c|c|}
\hline a & 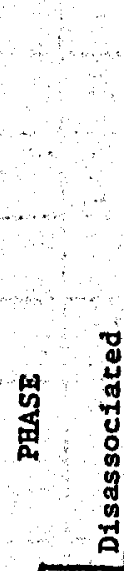 & $\begin{array}{ll} \\
\end{array}$ & 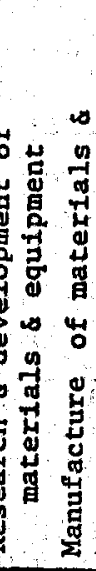 & 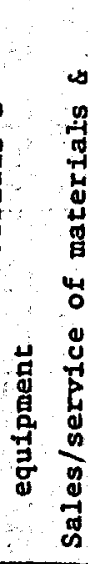 & 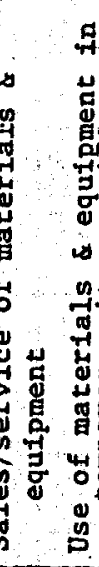 & 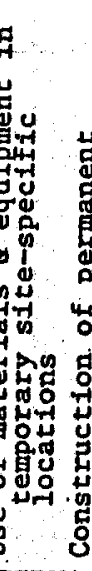 & 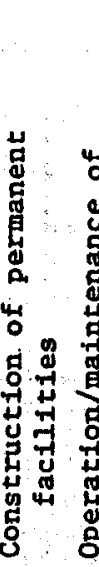 & 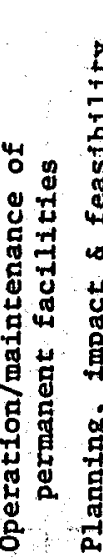 & 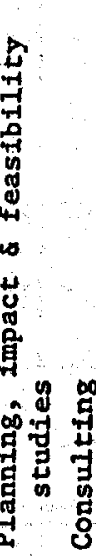 & 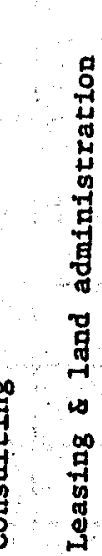 & 怤 & 胥 & 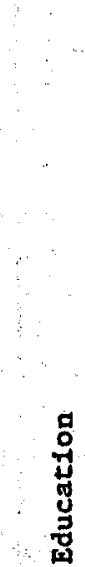 & & 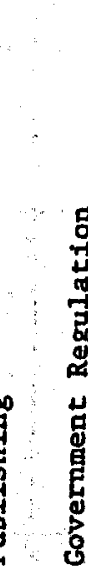 & 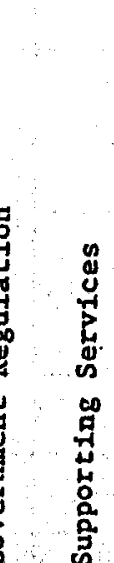 & $\begin{array}{l}\text { Hortzontal } \\
\frac{\text { Totals }}{\text { Tor }}\end{array}$ \\
\hline Disassactated & & 675 & 5 & 195 & & & & 532 & 192 & 1484 & 50 & 164 & 62 & 171 & 625 & 1206 & 5361 \\
\hline $\begin{array}{l}\text { Reswirce Exploration/assessment } \\
\text { (exclusive of drilling) }\end{array}$ & 1794 & 44445 & 19 & 72 & 1852 & 143 & 296 & 316 & 378 & 896 & 5 & 2 & 26 & 12 & 45 & 6 ( 1 & 10297 \\
\hline $\begin{array}{l}\text { Rescrvo1r des gn/development } \\
\text { (exclusive of drilling) }\end{array}$ & 280 & 1020 & 246 & 122 & 290 & 43 & 136 & 265 & 98 & 14 & & & 12 & & 26 & & 2552 \\
\hline Well drilling \& drilling & 1247 & 834 & 483 & 507 & 2510 & 58 & 183 & 24 & 56 & 3 & 1 & & & & 140 & 19 & 6065 \\
\hline $\begin{array}{l}\text { services } \\
\text { Plant design \& construction }\end{array}$ & 261 & 278 & 74 & 5 & 133 & 1924 & & 211 & 49 & 2 & 3 & 2 & & & 60 & 40 & 3042 \\
\hline steam production/transmission & 1011 & 202 & 1 & 6 & & 230 & 74 & & 9 & 35 & 2 & & & & 17 & & 1587 \\
\hline Space heating & 55 & 101 & & & & 30 & 23 & 78 & 26 & & & & & & 6 & & 319 \\
\hline Electrical energy production & 73 & 504 & 173 & 9 & 60 & 8 & 1256 & 19 & 61 & 24 & 5 & & & & 13 & & 2205 \\
\hline Agricultural applications & 152 & 197 & & & & 176 & & 82 & & & & & & & 6 & & 613 \\
\hline Non-electrical Industrial & & 55 & & & & & & 30 & & & & & & & & & 85 \\
\hline $\begin{array}{l}\text { applications } \\
\text { Envi ronmental }\end{array}$ & 132 & 446 & & & 8 & & & 749 & 161 & 184 & & 3 & & 30 & 83 & & 1796 \\
\hline Vertical Totals & 5005 & 8747 & 1001 & 721 & {$[5048]$} & 2612 & $1968 \mid$ & 2315 & 1056 & 2609 & 64 & 171 & $\begin{array}{r}100 \\
\text { GRA }\end{array}$ & 213 & 1021 & 33,92 & \\
\hline
\end{tabular}




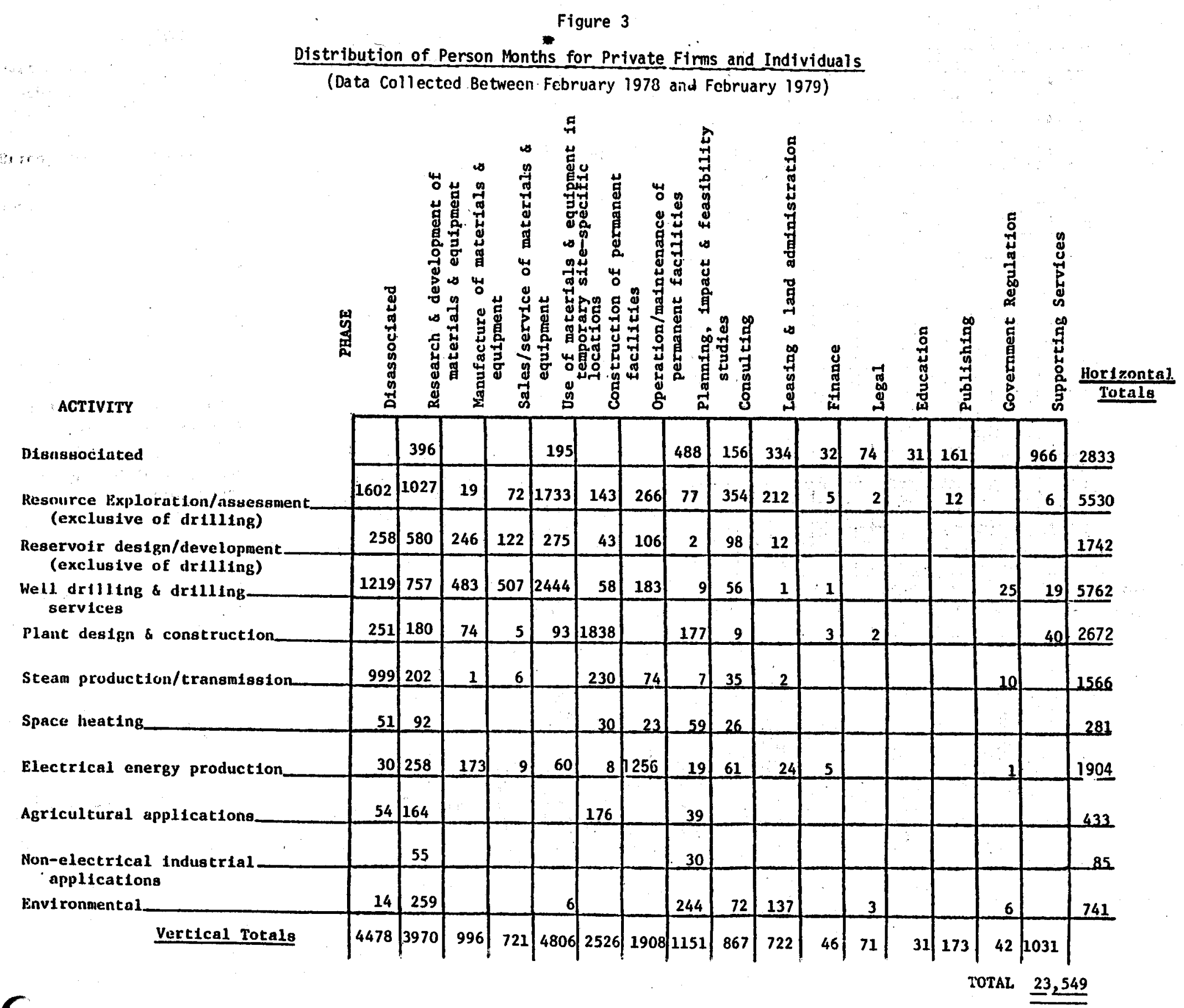


Figure 4

Distribution of Person Months for State and Local Government

(Data Collected Between February 1978 and February 1979)

ACTIVITY

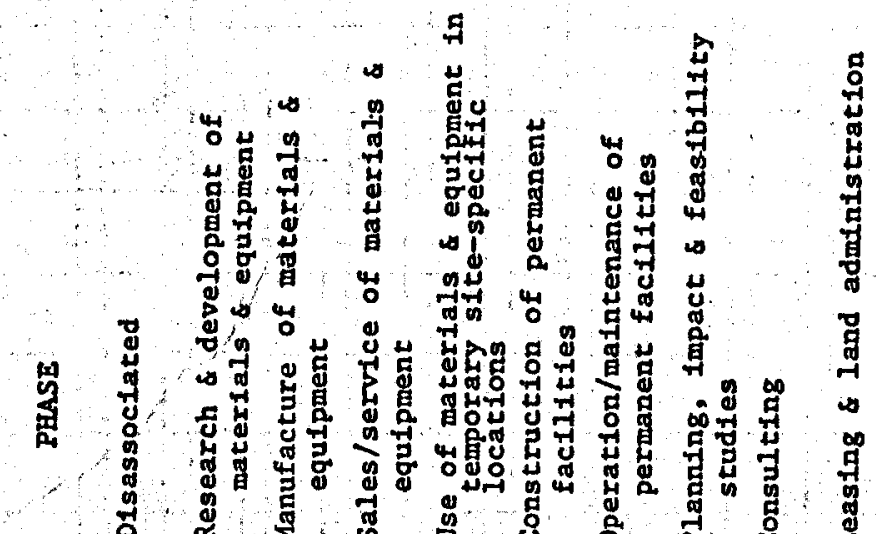

$$
\text { (1) }
$$

DLsassociated

Resource Exploration/assessment (excluatve of drilling)

Reservoir design/development

(exclusive of drilling)

Well drilling \& drilling services

Plant design \& construction

Steam production/cransmiasion

Space heating.

Electrical energy production

Agricultural applications

$$
\text { 1. }
$$

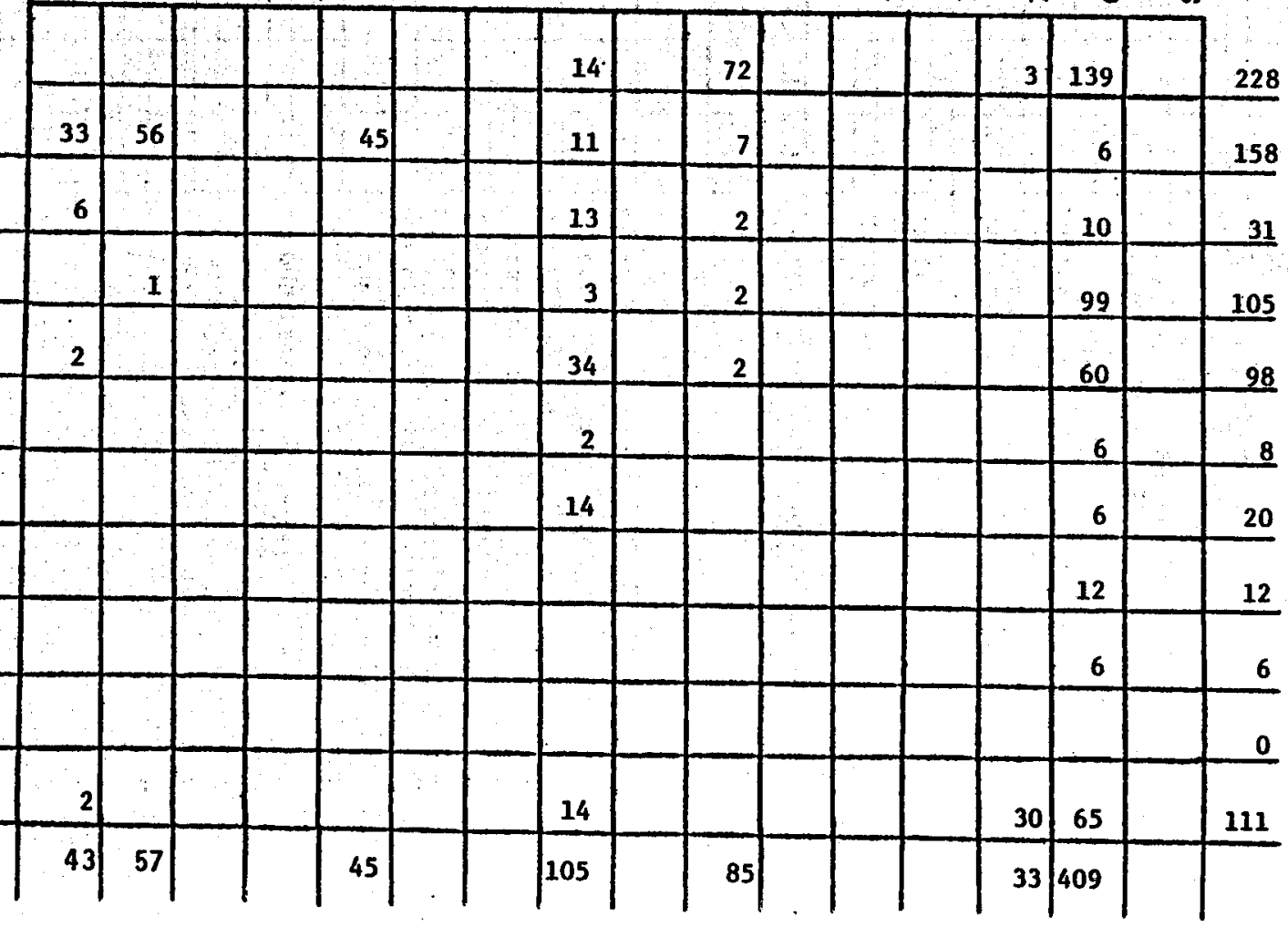

TOTAL $\underline{777}$

Non-electrical Industrial applications

Environmental

\begin{tabular}{|l|l|l|l|l|}
\hline 57 & & 45 & & \\
\hline
\end{tabular}


Figure 5

Distribution of Person Months for the Federal Government

(Data Collected Between February 1978 and Felruary 1979)

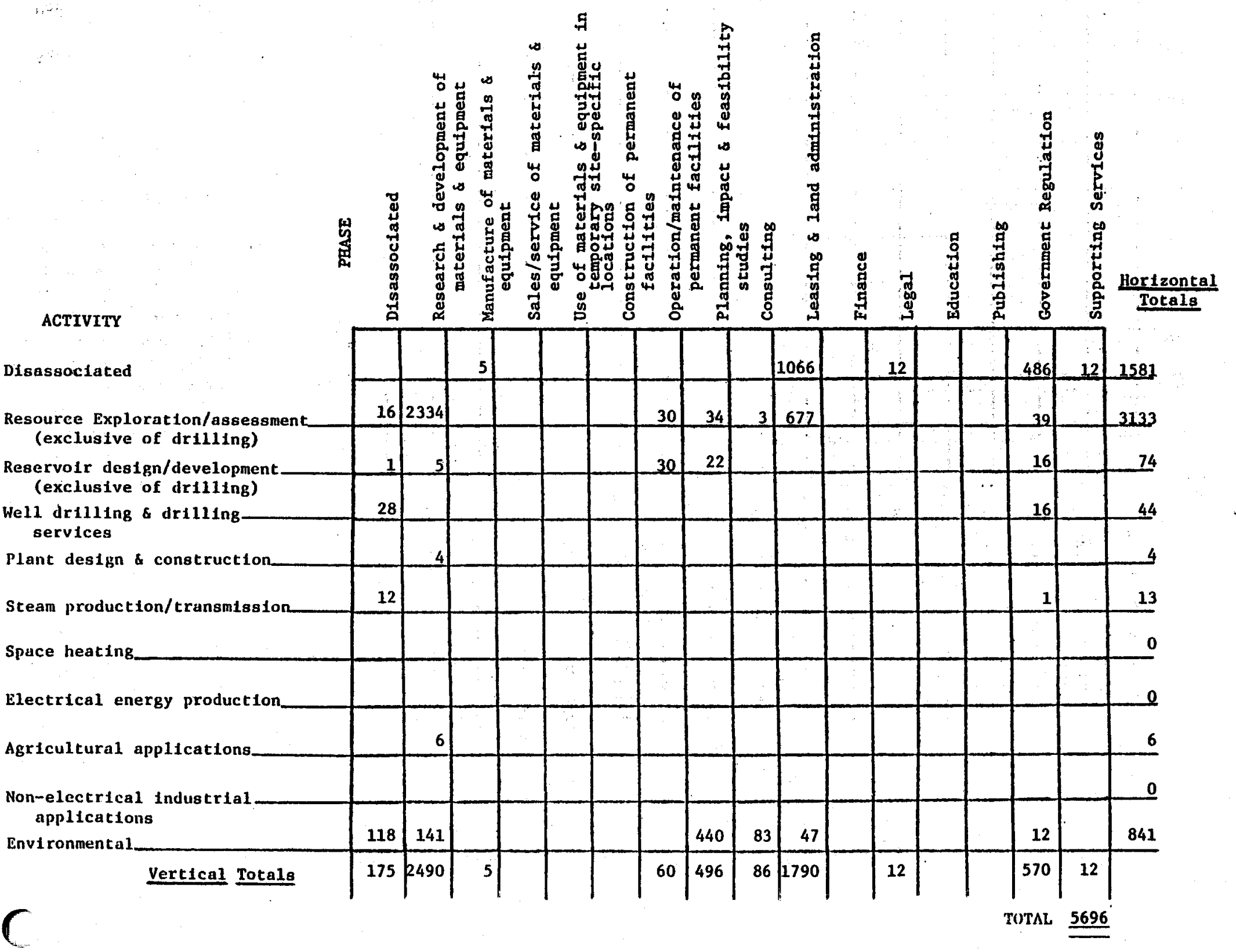


Distribution of Person Months for Educational Institutions

(Data Collected Between February 1978 and Fetruary 1979)

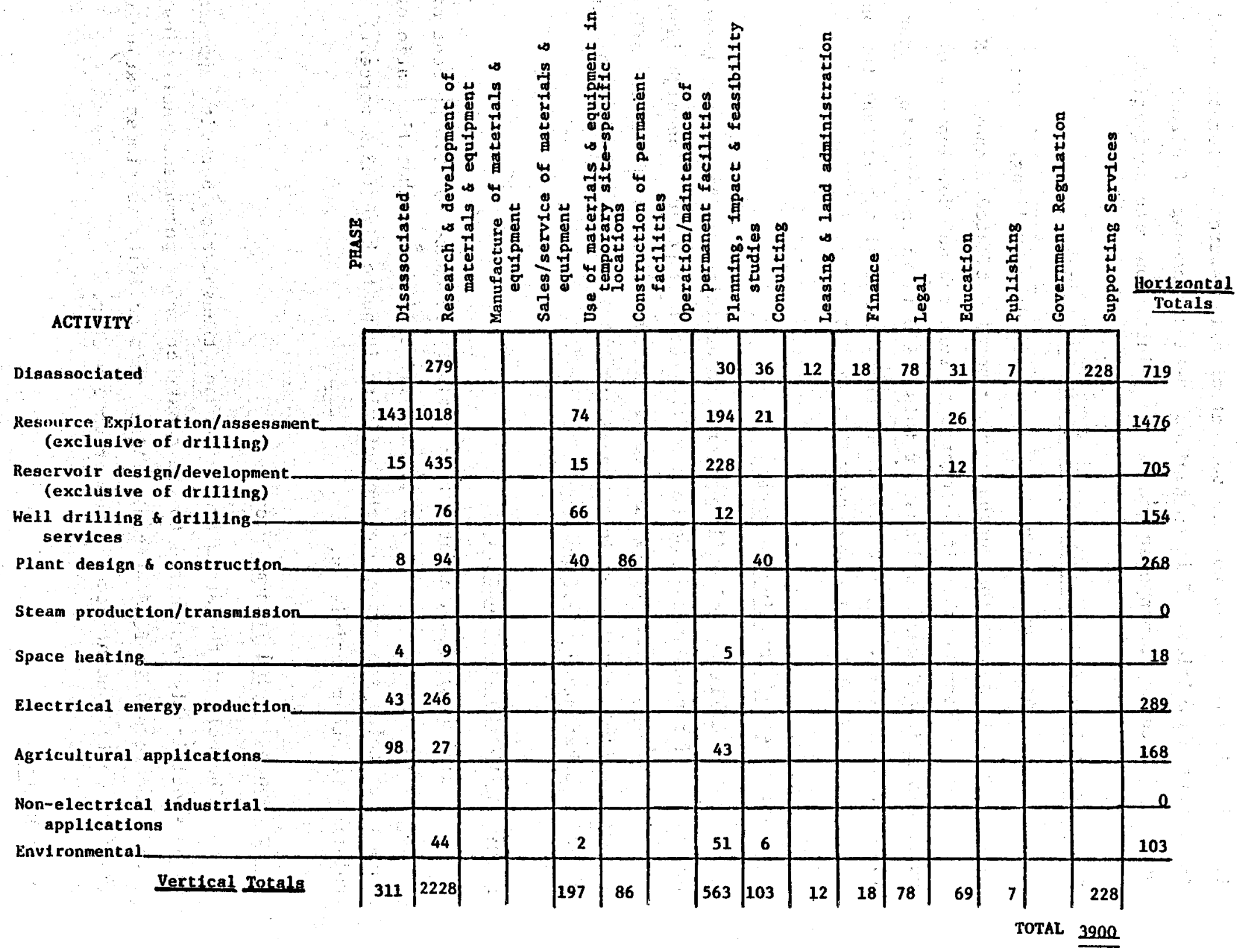


permanent facilities" and "operation and maintenance of permanent facilities," the share is only raised to 22.2 percent of all resource exploration and assessment activities. This emphasizes the large amoung of direct and indirect support (in terms of manpower) needed to maintain on-site activities.

Reservoir Design and Development (Excluding Drilling)

Reservoir Design and Development (excluding drilling) activity has 7.52 percent $(2,552$ person months) of the total estimated manpower. Nearly half, 1,020 person months, is allocated to research and development of materials and equipment, and most of this $R \& D$ is in the private sector (580 person months). Again, the direct on-site activities account for only 18.4 percent of the employment in this activity.

\section{Well Drilling and Drilling Services}

Well drilling and drilling services activity was the second largest activity and represented 18 percent of the total manpower. The high labor intensity of this activity is also reflected by the ratio of on-site efforts to total estimated manpower in the activity, 45.4 percent. The $R \& D$ efforts are also substantial, 13.8 percent.

\section{Plant Design and Construction}

Plant design and construction activity accounts for 9.0 percent of the total employment. It is similar to well drilling in that the ratio of on-site to total employment in the activity is quite high (63.2 percent) relative to other activities.

\section{Steam Production and Transmission}

The bulk of the steam production and transmission activity appears to be specifically designated to the construction of permanent facilities (i.e., the reservoir feed system). Also, this activity is almost exclusively ( 98.7 percent) concentrated in the private sector.

\section{Space Heating}

Space heating was the second smallest activity in terms of manpower with only 319 person months given. This activity is also highly concentrated 
in the private sector with 281 person months (or 88.1 percent).

Electrical Energy Production

An examination of all organizations combined reveals that all phases of electrical energy production accounted for 6.5 percent of total measured employment with over half of the manpower concentrated in operation and maintenance of permanent facilities. In the private sector only, electrical energy production is 8.1 percent of the total, with the operation and maintenance of permanent facilities accounting for nearly two-thirds of the activity in the private sector.

Agricultural Applications.

Agricultural application is another activity which is dominated by the private sector with 433 (of a total of 613) person months employed in the private sector. The major phases of manpower allocation are in research and development ( 197 person months) and construction of permanent facilities (176 person months).

Nonelectrical Industrial Applications

With only 85 person months, the nonelectrical industrial activity has the smallest amount of manpower. This allocation is divided between $R$ \& D (55 person months) and "planning, impact, and feasibility studies" (30 person months).

\section{Environmental}

As indicated in the personal interview phase and technology assessment phases of the study, it is felt that the environmental activity will be a growing area of employment. Environmental activity accounted for an estimated 5.3 percent $(1,796$ person months) of the total employment in 1977 . The basic phases of involvement were research and development, planning, impact, and feasibility studies, consulting, leasing, and land administration.

\section{Conclusions}

The discussion until now has been oriented toward the distribution of person months by activities and has demonstrated that the five major 
activities -- resource exploration and assessment, reservoir design and development, well drilling and drilling services, plant design and construction, and electrical energy production -- account for 24,161 person months, or 71.2 percent of a11 manpower measured in the survey. However, it cannot be concluded that this amount of manpower is used directly at the development site. To get a better estimate of the on-site activities one must examine particular phases of development.

Three phases of development - use of materials and equipment in temporary site-specific locations, construction of permanent facilities, and operation and maintenance of permanent facilities -- take into account most on-site activities. In fact, the total under these three categories for all organizations combined in 9,628 person months (or 28.4 percent). This total gives some indication of the proportion of the total employment which is not directly related to site-specific development.

\section{Final Mail Survey}

All organizations which responded to the first phase of the mall survey were candidates for the final survey unless they explicitly replied that further participation was not desired, or unless they were selected for the personal interview phase. A total of 367 organizations were left for the final survey, and these were distributed as follows:

\begin{tabular}{|c|c|}
\hline Private firm or individual & 251 \\
\hline State or local government & 33 \\
\hline Federal government & \\
\hline Education & 6 \\
\hline Tota1 & 36 \\
\hline
\end{tabular}

The final mail survey was designed to gain more specific knowledge about the structure of the industry, fluctuations in total employment and geothermal employment as a part of total employment, occupational structure by activities, attachment to on-site activities, and the proportion of budget and workforce devoted to research and development. The results from the survey as a whole were mixed, and each will be discussed in turn according to the areas cited above. 
Of the 367 organizations, a total of 232 were accounted for after an initial and a follow-up malling, and 214 had provided usable information.

Total mailed

Nonrespondents

Nondeliverables

No longer in the industry

Decided not to participate

No data supplied

Respondents who provided usable data
367

$-135$

$-4$

$-6$

$-4$

$-4$

214

Table 6 shows the response rates by organizational type based on the 214 respondents. Also listed are the means and medians of employment in person months by organizational type. The combined response rate of all organizations providing usable data was 59.9 percent $^{3}$, the combined mean was 54.5 , and the combined median was 13 . It should be noted that the large differences between the respective means and medians results from a large proportion of the total manpower being attributed to a relative few organizations in each category.

TABLE 6. EMPLOYMENT DATA BY ORGANIZATIONAL TYPE FOR FINAL MAIL SURVEY

\begin{tabular}{lccc} 
Organization Type & Response Rate & Mean & Median \\
\hline Private firm or individual & $54.5 \%$ & 62.3 & 12 \\
State or local government & $71.9 \%$ & 26.7 & 16 \\
Federal government & $78.3 \%$ & 59.6 & 30 \\
Education & $69.0 \%$ & 49.1 & 18 \\
\hline
\end{tabular}

\section{Employment Summary}

This part of the final mail survey had two purposes. The first was to gain some insight into the relative importance (in terms of manpower) of geothermal activities as compared to other activities in which

$3214 \div 357$ (total mailed less the nonindustry and nondeliverables) 
the organizations are involved. The second purpose was to obtain data for 1977 and 1978 to see if there was an obvious growth trend. These results are summarized in Table 7.

TABLE 7. RATIOS OF GEOTHERMAL TO TOTAL EMPLOYMENT BY ORGANIZATIONAL TYPE

\begin{tabular}{lcc}
\hline & 1977 & 1978 \\
\hline Private firm or individual & $\frac{779}{326,811}=.24 \%$ & $\frac{1008}{347,541}=.29 \%$ \\
State and local government & $\frac{127}{2,838}=4.47 \%$ & $\frac{155}{3,025}=5.12 \%$ \\
Federal government & $\frac{285}{47,854}=.60 \%$ & $\frac{258}{47.639}=.54 \%$ \\
Educational institution & $\frac{185}{14,922}=1.24 \%$ & $\frac{227}{15,841}=1.43 \%$ \\
\hline \hline
\end{tabular}

A central problem in forming geothermal to total employment ratios is the relative position in each organization's hierarchial structure which responded to the questionnaire. This is especially true for the different levels of government and for educational institutions. Therefore, as a first point it may be argued that the geothermal to total employment ratios demonstrate the relative unimportance of the industry in relation to the total employment of the organizations involved. Given the low ratios (for 1977 and 1978 respectively) -- educational institutions (1.24\% and $1.43 \%)$, federal government (.6\% and .54\%), state and local government (4.47\% and 5.12\%), and the private sector (.24\% and .29\%) -- this appears to be true for any particular organizational group, but it is important to keep in mind that some organizations (especially in the private sector) may be totally dependent on the geothermal industry.

One notable feature of the ratios is that they demonstrate a slight increase between 1977 and 1978, with the exception of the federal government. However, if one looks at the increase for all organizational types added together, it only amounts to .05 percent.

Finally, the ratio for the private firms surveyed by personal interview was 1.42 percent $(923 \div 65,123)$. This is considerably higher 
than the mall survey (.23 percent), but it is also not surprising since the larger firms were purposely included in the personal interviews.

\section{Occupational Employment in Geothermal Activities}

The objective was to obtain an occupational profile by the different activities in the industry. However, survey restrictions imposed by the Office of Management and Budget resulted in only a very general and less useful picture of the occupational structure in the industry (Figures? through 11). The following discussion is based on data pertaining to broad occupational categories and is presented in the matrices on the following pages.

One might expect the occupational group of scientists and engineers to represent a large proportion of the total quantity of manpower in the industry. However, based on the 200 respondents to this part of our survey, the scientists and engineers category not only assumes a large proportion but also clearly dominates the manpower structure of the industry. With all organization types taken together scientists and engineers account for 7,341 (or 59.3 percent) of the total 12,375 measured person months. This preponderance exists for all organizations taken together as well as for each organizational type examined separately.

The above description holds true not only for each organizational type but for each activity within any given organizational type, also, with only two exceptions. In the activity of well drilling and drilling services, the "all others" category is the largest for all organizational types combined and for (the separate category pertaining to) the sector. The other exception is in the private sector activity of electrical energy production and transmission in which the dominant occupational group is technicians.

\section{Geographic Sites}

It was attempted to have the organizations respond by their involvement at particular Known Geothermal Resource Areas (KGRA's). The initial intent was to try to assess the magnitude of labor impact on a local level. However, this was not a highly productive approach since many firms did not know the formal KGRA designations or replied with some other geographic 
FIGURE 7. TOTAL PERSON MONTHS FOR ALI ORGANIZATIONAL TYPHS

(Data Collected between March 1979 and May 1979)

\begin{tabular}{|c|c|c|c|c|c|}
\hline Activity & $\begin{array}{l}\text { Scientists } \\
\text { \& Engineers }\end{array}$ & Technicians & $\begin{array}{l}\text { Skllied } \\
\text { Workers }\end{array}$ & $\begin{array}{l}\text { All } \\
\text { Others }\end{array}$ & $\begin{array}{l}\text { Horizontal } \\
\text { Totals }\end{array}$ \\
\hline $\begin{array}{l}\text { Resource Exploration \& Assess- } \\
\text { ment (exclusive of driling) }\end{array}$ & 2436 & 568 & 85 & 359 & 3448 \\
\hline $\begin{array}{l}\text { Reservolr Design \& Development } \\
\text { (exclusive of drilling) }\end{array}$ & 460 & 196 & 2 & 70 & 728 \\
\hline $\begin{array}{l}\text { Well Drilling \& Drilling } \\
\text { Services }\end{array}$ & 522 & 401 & 508 & 597 & 2028 \\
\hline Plant Design and Construction & 554 & 139 & 98 & 59 & 850 \\
\hline $\begin{array}{l}\text { Steam Production and } \\
\text { Transmission }\end{array}$ & 267 & 71 & 20 & 72 & 430 \\
\hline $\begin{array}{l}\text { Electrical Energy Production } \\
\text { \& Transmission }\end{array}$ & 197 & 39 & 0 & 14 & 250 \\
\hline Space Heating & 84 & 4 & 1 & 35 & 121 \\
\hline Agriculture Operations & 120 & 33. & 0 & 8 & 161 \\
\hline $\begin{array}{l}\text { Non-electric Industrial } \\
\text { Applications }\end{array}$ & 410 & 24 & 14 & 36 & 484 \\
\hline Environmental & 988 & 260 & 6 & 134 & 1388 \\
\hline Other & 1306 & 441 & 61 & 679 & 2487 \\
\hline Vertical Totals & 7341 & 2176 & 795 & 2063 & $\begin{array}{l}\text { Matrix Total } \\
12,375\end{array}$ \\
\hline
\end{tabular}


FIGURE 8. TOTAL PERSON MONTHS FOR PRIVATE SECTOR

(Data Collected between March 1979 and May 1979)

\begin{tabular}{|c|c|c|c|c|c|}
\hline ActIvity & $\begin{array}{l}\text { Scientists } \\
\text { \& Engineers }\end{array}$ & Techniclans & $\begin{array}{l}\text { Skilled } \\
\text { Workers }\end{array}$ & $\begin{array}{l}\text { All } \\
\text { Others }\end{array}$ & $\begin{array}{l}\text { Horlzontal } \\
\text { Totals }\end{array}$ \\
\hline $\begin{array}{l}\text { Resource Exploration \& Assess- } \\
\text { ment (exclusive of drlling) }\end{array}$ & 1559 & 399 & 52 & 185 & 2195 \\
\hline $\begin{array}{l}\text { Reservoir Design \& Development } \\
\text { (exclusive of drilling) }\end{array}$ & 227 & 114 & 0 & 67 & 408 \\
\hline $\begin{array}{l}\text { Well Drilling \& Drilling } \\
\text { Services }\end{array}$ & 364 & 331 & 430 & 475 & 1600 \\
\hline Plant Design and Construction & 374 & 63 & 14 & 53 & 504 \\
\hline $\begin{array}{l}\text { Steam Production and } \\
\text { Transmission }\end{array}$ & 71 & 22 & 0 & 6 & 99 \\
\hline $\begin{array}{l}\text { Electrical Energy Production } \\
\text { \& Transmission }\end{array}$ & 24 & 30 & 0 & 10 & 64 \\
\hline Space Heating & 28 & 2 & 0 & 35 & 65 \\
\hline Agriculture Operations & 32 & 14 & 0 & 8 & 54 \\
\hline $\begin{array}{l}\text { Non-electric Industrial } \\
\text { Applications }\end{array}$ & 47 & 2 & 0 & 2 & 51 \\
\hline Environmental & 448 & 74 & 0 & 2 & 524 \\
\hline Other & 537 & 171 & 39 & 54 & 801 \\
\hline Vertical Totals & 371 & 1222 & 535 & 897 & $\begin{array}{l}\text { Matrix Total } \\
6365\end{array}$ \\
\hline
\end{tabular}


FIGURE 9. TOTAL PERSON MONTHS FOR STATE AND LOCAL GOVERNMENT

(Data Collected between March 1979 and May 1979)

\begin{tabular}{|c|c|c|c|c|c|}
\hline Activity & $\begin{array}{r}\text { Scientists } \\
\text { \& Engineers }\end{array}$ & Technicians & $\begin{array}{l}\text { Skilled } \\
\text { Workers }\end{array}$ & $\begin{array}{c}\text { All } \\
\text { Others }\end{array}$ & $\begin{array}{l}\text { Horizontal } \\
\text { Totals }\end{array}$ \\
\hline $\begin{array}{l}\text { Resource Exploration \& Assess } \\
\text { ment (exclusive of drilling) }\end{array}$ & 172 & 21 & 0 & 6 & 199 \\
\hline $\begin{array}{l}\text { Reservoir Design \& Development } \\
\text { (exclusive of drilling) }\end{array}$ & 10 & 0 & 1. & 0 & 11 \\
\hline $\begin{array}{l}\text { Well Drilling \& Drilling } \\
\text { Services }\end{array}$ & 27 & 0 & 0 & 12 & 39 \\
\hline Plant Design and Construction & 5 & 0 & 0 & 0 & 5 \\
\hline $\begin{array}{l}\text { Steam Production and } \\
\text { Transmission }\end{array}$ & 4 & 3 & 0 & 0 & 7 \\
\hline $\begin{array}{l}\text { Hilectrical Energy Production } \\
\text { \& Transmission }\end{array}$ & 0 & 0 & 0 & 0 & 0 \\
\hline Space Heating & 12 & 0 & 1 & 0 & 13 \\
\hline Agriculture Operations & 2 & 0 & 0 & 0 & 0 \\
\hline $\begin{array}{l}\text { Non-electric Industrial } \\
\text { Applications }\end{array}$ & 61 & 0 & 14 & 20 & 95 \\
\hline Environmental & 60 & 6 & 0 & 12 & 78 \\
\hline Other & 56 & 0 & 1 & 106 & 163 \\
\hline Vertical Total & 409 & 30 & 17 & 156 & $\begin{array}{l}\text { Matrix Total } \\
612\end{array}$ \\
\hline
\end{tabular}


FIGURE 10. TOTAL PERSON MONTHS FOR FEDERAL GOVERNMENT

(Data Collected between March 1979 and May 1979)

\begin{tabular}{|c|c|c|c|c|c|}
\hline Activity & $\begin{array}{l}\text { Scientists } \\
\text { \& Engineers }\end{array}$ & Technicians & $\begin{array}{l}\text { Skilled } \\
\text { Workers }\end{array}$ & $\begin{array}{l}\text { All } \\
\text { Others }\end{array}$ & $\begin{array}{l}\text { Horizontal } \\
\text { Totals }\end{array}$ \\
\hline $\begin{array}{l}\text { Resource Exploration \& Assess- } \\
\text { ment (exclusive of driling) }\end{array}$ & 96 & 26 & 1 & 18 & 141 \\
\hline $\begin{array}{l}\text { Reservoir Design \& Development } \\
\text { (exclusive of driling) }\end{array}$ & 45 & 4 & 1 & 3 & 53 \\
\hline $\begin{array}{l}\text { We11 Drilling \& Drilling } \\
\text { Services }\end{array}$ & 113 & 48 & 2 & 0 & 163 \\
\hline Plant Design and Construction & 2 & 0 & 0 & 0 & 2 \\
\hline $\begin{array}{l}\text { Steam Production and } \\
\text { Transmission }\end{array}$ & 0 & 0 & 0 & 0 & 0 \\
\hline $\begin{array}{l}\text { Hectrical Energy Production } \\
\text { \& Transmission }\end{array}$ & 0 & 9 & 0 & 0 & 9 \\
\hline Space Heating & 0 & 0 & 0 & 0 & 0 \\
\hline Agriculture Operations & 0 & 0 & 0 & 0 & 0 \\
\hline $\begin{array}{l}\text { Non-electric Industrial } \\
\text { Applications }\end{array}$ & 0 & 0 & 0 & 0 & 0 \\
\hline Environmental & 105 & 78 & 0 & 16 & 199 \\
\hline Other & 53 & 6 & 4 & 81 & 144 \\
\hline Vertical Totals & 414 & 171 & 8 & 118 & $\begin{array}{l}\text { Matrix Total } \\
711\end{array}$ \\
\hline
\end{tabular}


FIGURE 11. TOTAL PERSON MONTHS FOR EDUCATIONAL INSTITUTIONS

(Data Collected between March 1979 and May 1979)

\begin{tabular}{|c|c|c|c|c|c|}
\hline Activity & $\begin{array}{l}\text { Scientists } \\
\text { \& Engineers }\end{array}$ & Technicians & $\begin{array}{l}\text { Skilled } \\
\text { Workers }\end{array}$ & $\begin{array}{c}\text { All } \\
\text { Others }\end{array}$ & $\begin{array}{l}\text { Horizontal } \\
\text { Totals }\end{array}$ \\
\hline $\begin{array}{l}\text { Resource Exploration \& Assess- } \\
\text { ment (exclusive of driling) }\end{array}$ & 609 & 122 & 32 & 150 & 913 \\
\hline $\begin{array}{l}\text { Reservoir Design \& Development } \\
\text { (exclusive of drilling) }\end{array}$ & 178 & 78 & 0 & 0 & 256 \\
\hline $\begin{array}{l}\text { Well Drilling \& Drilling } \\
\text { Services }\end{array}$ & 4 & 0 & 0 & 0 & 4 \\
\hline Plant Design and Construction & 131 & 0 & 0 & 0 & 131 \\
\hline $\begin{array}{l}\text { Steam Production and } \\
\text { Transmission }\end{array}$ & 0 & 0 & 0 & 0 & 0 \\
\hline $\begin{array}{l}\text { Electrical Energy Production } \\
\text { \& Transmission }\end{array}$ & 1 & 0 & 0 & 0 & 1 \\
\hline Space Heating & 9 & 2 & 0 & 0 & 11 \\
\hline Agriculture Operations & 10 & 1 & 0 & 0 & 11 \\
\hline $\begin{array}{l}\text { Non-electric Industrial } \\
\text { Applications }\end{array}$ & 8 & 0 & 0 & 0 & 8 \\
\hline Environmental & 47 & 0. & 0 & 0 & 47 \\
\hline other & 310 & 22 & 15 & 16 & 363 \\
\hline Vertical Totals & 1307 & 225 & 47 & 166 & $\begin{array}{l}\text { Matrix Total } \\
1745\end{array}$ \\
\hline
\end{tabular}


designation. Also, involvement in specific areas is only a short-term phenomenon for most organizations, and it is not possible to determine the proportion of their total geothermal employment which may be involved at any particular area at a given time.

It is noteworthy that most organizations did view themselves as involved with at least one KGRA. This indicates the strength of attachment to site-specific developments of the final survey group. Table 8 gives a breakdown of the respondents to this question.

\section{$\underline{\text { Research and Development }}$}

Table 9 shows a partial breakdown, by organization type, of the responses to the question, "What percent of your organization's total geothermal budget in 1977 was in research and development?" Note that many organizations left part or all of this section blank. These are deleted from the count, and only the organizations which explicitly stated zero are counted in this category.

One particular observation from Table 9 is that many firms $(34) \cdot$ in the private sector are exclusively involved in research and development. In other words, as a proportion of total respondents (111) to this category, 30.6 percent of the firms have their budget 100 percent allocated to research and development activities. This Is also quite comparable to the results from the personal interview survey in which five out of the twenty firms responding to this question were 100 percent involved in research and development. Based on the discussion of occupational employment by geothermal activity, It appears that $R$ \& $D$ underpins much of the relatively high proportion of employment of scientists and engineers in the industry.

Table 10 is based on responses to the question, "What percent of your organization's total geothermal workforce is engaged in research and development?" The table indicates that the $R$ \& $D$ budget allocation is highly correlated with the relative proportion of employment in this activity in the private sector; that is, 52.1 percent of private firms responding to this category indicated that some proportion of their manpower was involved in research and development efforts. This is slightly higher than the 49.6 percent which gave the same indication for the prior question on budget allocation. 
TABLE 8. INVOLVEMIENT WITH KNOWN GEOTHERMAL RESOURCE AREAS (KGRA'S) 1977-1978

\begin{tabular}{lcccc}
\hline & $\begin{array}{c}\text { Indicated } \\
\text { no } \\
\text { involvement } \\
\text { at a KGRA }\end{array}$ & $\begin{array}{c}\text { Not } \\
\text { Responding } \\
\text { to the } \\
\text { Question }\end{array}$ & $\begin{array}{c}\text { Indicated } \\
\text { involvement } \\
\text { with at least } \\
\text { one KGRA }\end{array}$ & $\begin{array}{c}\text { Horizontal } \\
\text { Totals }\end{array}$ \\
\hline $\begin{array}{l}\text { Private firm or } \\
\text { individual } \\
\begin{array}{l}\text { State or local } \\
\text { government }\end{array}\end{array}$ & 38 & 12 & 83 & 133 \\
$\begin{array}{l}\text { Federal government } \\
\text { Educational }\end{array}$ & 3 & 2 & 18 & 23 \\
& 2 & 0 & 16 & 18 \\
& 11 & 3 & 26 & 40 \\
\hline
\end{tabular}

TABLE 9, R \& D BUDGET AS A

PERGERT OF TOTAL BUDGET 1977

\begin{tabular}{lc|c|c|c|}
\hline & \multicolumn{4}{c}{ Percent of budget } \\
\cline { 2 - 5 } & 100 & $50-99$ & $1-49$ & 0 \\
\hline $\begin{array}{l}\text { Private firms or } \\
\text { individuals } \\
\begin{array}{c}\text { State and local } \\
\text { governments }\end{array}\end{array}$ & 34 & 15 & 17 & 45 \\
$\begin{array}{l}\text { Federal government } \\
\text { Educational institutions }\end{array}$ & 16 & 1 & 2 & 9 \\
& 5 & 0 & 0 & 12 \\
\hline \hline
\end{tabular}


TABLE 10. PERCENT OF GEOTHERMAL WORKFORCE ENGAGED $T N R$ \& $D$

1978

\begin{tabular}{|c|c|c|c|c|}
\hline & \multicolumn{4}{|c|}{ Percent in $R \& D$} \\
\hline & 100 & $50-99$ & $1-49$ & 0 \\
\hline \# & responding & \# responding & \# responding & \# responding \\
\hline $\begin{array}{l}\text { Private firms or } \\
\text { individuals }\end{array}$ & 32 & 17 & 21 & 47 \\
\hline $\begin{array}{l}\text { State and local } \\
\text { governments }\end{array}$ & 12 & 1 & 0 & 8 \\
\hline Federal government & 5 & 0 & 0 & 12 \\
\hline Educational institutions & 20 & 2 & 5 & 6 \\
\hline
\end{tabular}

\section{Conclusion}

Though the matrices on which much of the discussion in this part of the study is based contain some ambiguities, they have proven to be a useful tool in analyzing where manpower is allocated in the geothermal industry. For example, it is obvious that research and development is the dominant phase of activity in the industry, and the dominant activity is resource exploration and assessment. Both of these reflect the infant nature of the geothermal industry.

Another finding is that scientists and engineers compose more than half of the estimated manpower requirements in the industry. Finally, it appears that manpower is highly concentrated in only a few firms which form the stable core of employment for the industry and that a large number of smaller peripheral firms are marginally attached to the industry. 
Chapter 3

CURRENT AND POTENTIAL OCGUPATIONAL STRTIGENCIES

AND THE OCCUPATIONAL STRUCTURE OF THE INDUSTRY

\section{Introduction}

The personal interview phase of the manpower assessment study was conducted in order to obtain detailed information about development sites, current or potential occupational bottlenecks, emerging occupations, the occupational structure in certain areas of the industry, and additional information that would be helpful in making manpower projections. The interviews were conducted from October of 1978 until February of 1979 and covered thirty-five firms, five of which were included for purposes of training an interviewer. With the exception of the firms included for training purposes, the following is an outline of the criteria used for selecting the participating firms.

\section{Criteria for selection}

The firms selected for personal interview were drawn from the responses to the initial questionnaire mailings. Only the private sector was investigated because it is in this area that the key decisions will be made determining the growth and needs of the geothermal industry. Also, It appeared that a minimum of thirty to forty firms would have to be interviewed in order to develop an acceptable consensus. Therefore, given the limited resources, the decision was made not to include the government sector and educational institutions.

Though the number of interviews was necessarily limited, a relatively small number of firms form the most active and heavily involved portion of the industry. The firms chosen for personal interviews are representative of those which are key to the industry's structure and potential growth.

Based on the preliminary results from the initial questionnaire mailings and upon other information pertaining to the geothermal industry, 
key firms could be identified by their type of activity in the industry and the quantity of manpower devoted to these activities. Hence, one criterion was to try to include a variety of activities, and the other was to interview the firms responsible for the most concentrated employment in the geothermal industry. It was apparent at the time of selection that approximately ten to twelve firms were the primary employers in the industry.

Firms involved in supporting services in the industry were not of primary concerm in this phase of the study. Instead, interview efforts were devoted to those firms directly involved in a major activity at a geothermal site. Finally, location did not prove to be a useful criterion. Though it appears that most major firms are based in California; their activities are usually conducted at several different sites and often in several different states.

\section{Evaluation of the Personal Interview Approach}

In general, the interviews yielded less information than was anticipated. Several factors contributed to this result. Some firms were highly reluctant to provide information because they feared it might fall into their competitors' hands, despite pronounced assurances that all information would remain confidential. For example, a few firms admitted that they had conducted their own internal studies on manpower requirements and other geothermal needs but would not make them available. In some cases this was understandable because of the complexities of joint ventures and the rights of proprietary information. However, the major problem appears to be the prevailing uncertainty which permeates all phases of the industry and includes the broad spectrum of activities ranging from resource definition to the determination of the life of a reservoir. The uncertainty itself emanates from two basic causes. One is the infant nature of the industry and the accompanying technological and economic unknowns. The other is institutional constraints to development -- definition of property rights, taxation policies, and regulatory controls -- which must be resolved. In all phases of this study the institutional problems were singled out as the most cumbersome to the growth and development of the geothermal industry. 


\section{Results of the Personal Interviews}

The following is a short summary of the aggregated responses to each section of the interview guide.

\section{Employment Summary}

Table 11 shows the replies to this section. Note that the numerical values are expressed in terms of number of employees rather than in person months.

\section{Occupational Stringencies}

The majority (eighteen) of the firms interviewed anticipated problems in recruiting an adequate workforce. No significant pattern based on the type of firm or the size of firm was exhibited in these responses. Comments by the interviewees revealed that shortages of skilled personnel and laborers could be attributed to either remote development sites or to areas of heavy development activities which taxed the local manpower pool, or to a combination of the two. The problem of remote development sites was viewed as a short-term phenomenon if the activity was of a short duration exploratory nature. Geothermal sites in Southern Utah and Nevada were mentioned in this group. The heavy development activities (reservoir completion, power plant construction, and power plant operation and maintenance) posed more serious, long-term problems but appeared to be limited to developments at Imperial Valley and The Geysers. 4

The other category of shortages, scientific and technical personnel, was viewed by the interviewees as a part of an overall national problem. Most firms responding with this concern felt that the geothermal industry was at a considerable competitive disadvantage with the oil and gas industries in recruiting this type of manpower. Reasons given were the uncertainties associated with a new industry and the additional training required to acquaint new personnel with the unique aspects of the geothermal resource.

\footnotetext{
Thecent assessments of the socioeconomic impacts of proposed geothermal developments in these areas can be found in National science Foundation, Imperial County California: Geothermal Element, 1975, and in California Resources Conservation and Development Commission, Consultant Report: Environmental Analysis for Geothermal Energy Development in The Geysers Region, Volume II: Master Environmental Assessment, May 1977.
} 
TABLE 11. EMIPLOYMENT SUMMARY *

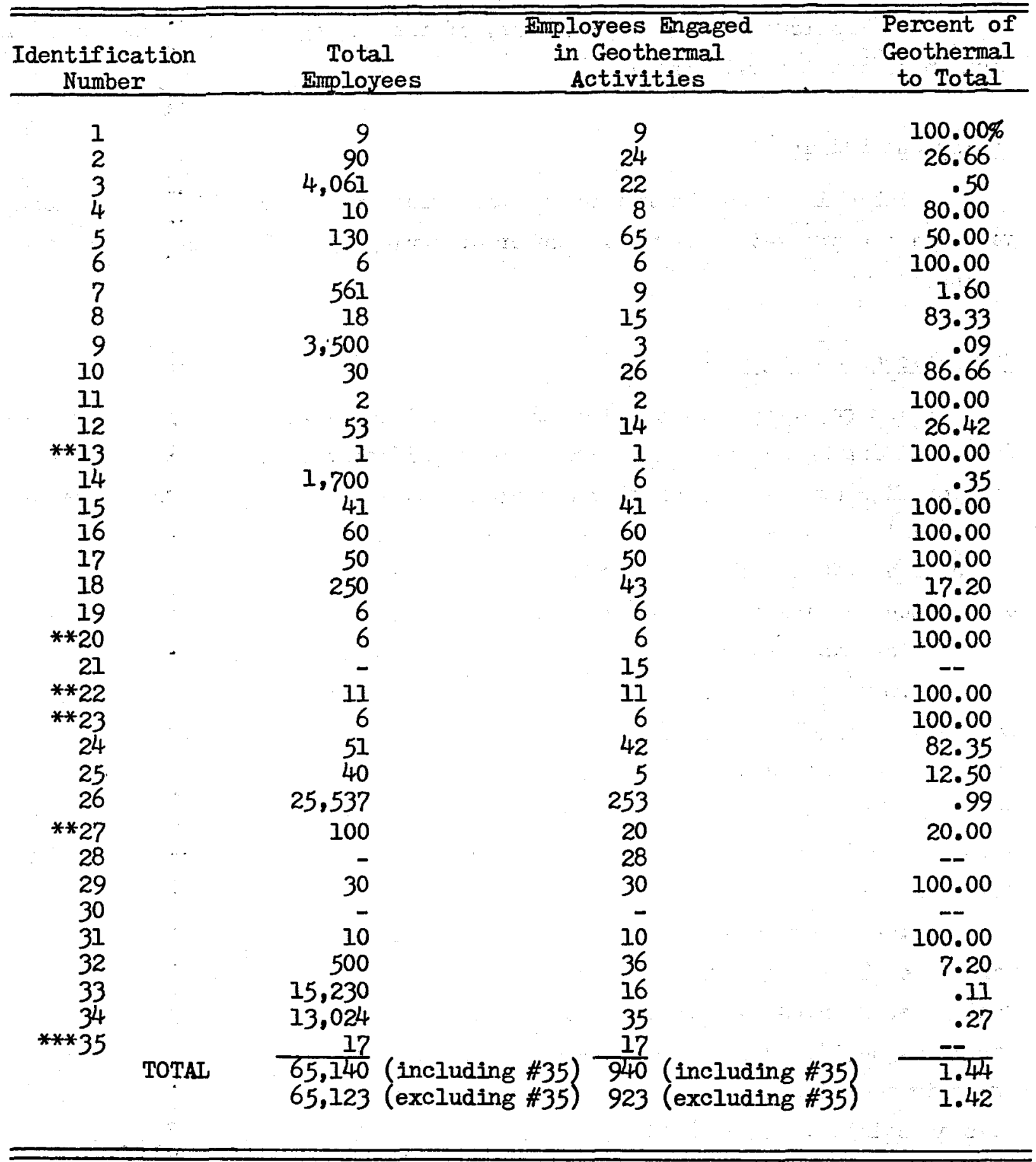

*Data collected from October of 1978 through February 1979. **Firms included for purposes of training the interviewer. ***Deleted from further quantitative analysis because employees were in other countries. 
The problem occupations that were discussed in the interview are divided Into two groups, primary problem occupations and secondary problem occupations. The primary problem occupations are the ones most often mentioned and viewed as the most serious. The secondary problem occupations were not revealed as being widespread and were generally of a short-run nature.

\section{Primary Problem Occupations}

Geologists. Employers cited a pronounced shortage of geologists with experience in hard rocks (granite) and volcanics. Skills in one type of resource (e.g., oil or gas) are not necessarily sufficient for work in the geothermal industry, especially since the geothermal resource itself is not of a homogeneous nature. A master's degree appears to be the minimum requirement, but orientation to the geothermal resource is still necessary.

Geophysicists. The comments directed at geologists also apply to geophysicists. One observer did point out that communication between geologists and geophysicists needs to be improved (e.g., in the area of fault identification).

Reservoir Engineers. The geothermal industry faces stiff competition from the 0 il and gas industries in the recruitment of reservoir engineers. This problem is compounded by the urgent need in the geothermal industry to improve techniques of reservoir assessment and development in order to reduce the risk to investors.

Environmental Engineers. Although only one firm strongly emphasized this occupation as a current problem (the areas of expertise needed being in discharge of hot fluids, discharge of gases, and ground subsidence), it is concluded that its potential as a significant bottleneck occupation is considerable. This view is reinforced by the technology assessment portion of this study in which it is pointed out that environmental problems will become more serious as the industry grows, and the various forms of the resource are utilized. Drill Rig Personnel. The problems here exist from the lowest to the highest skill levels employed at the drilling site. The acquisition of skills and experience and the progression up the job ladder from 
roustabout, driller assistant, driller foreman, to job foreman is hindered by the nature of drilling work, which involves long periods of travel and constant movement to different sites resulting in high turnover rates. Recruitment of unskilled labor is basically done by advertising in the work locale and skill acquisition is a function of on-the-job training. A couple of firms did point out that the problem of high turnover rates was much less pronounced in areas where drilling projects were of a long-term nature (e.g., requiring a large number of local wells). Finally, drilling machinists were also mentioned as a problem, essentially because of a lack of qualified mechanics.

In conclusion, it appears that practically all the specifically geothermal related training ranging from the unskilled labor to the scientific and technical personnel is conducted on the job. This was found to be true not only of the occupations mentioned above, but also of occupations that pose little or no constraint on industry growth (e.g., construction, operation, and maintenance of geothermal power plants).

Some training of scientific and technical personnel is received in an indirect manner through research assistantships for graduate students to work on geothermal topics. One other area of training at this level is through short courses of instruction offered periodically by the Geothermal Resources Council. These courses vary and cover a variety of geothermal activities of a technical and nontechnical nature.

Also, the Oregon Institute of Technology conducted a study in March 1976 which was geared toward assessing the industry's interest in a formal training program in various geothermal activities. However, state funds were not forthcoming to support the program because of the perceived uncertainty of development. Based on research results in this study, it is recommended that the feasibility of such a program be reconsidered, possibly on a federally sponsored basis. One of the major complaints of the firms was that costly on-the-job training was the only way to acquaint scientists and engineers with unique geothermal characteristics. The result is that they are less able to compete with the oil and gas industries, which can draw recruits from university curricula that favor their specialized needs.

The root cause of occupational stringencies appears to be that the geothermal industry, in contrast to the oil and gas industries, cannot draw 
on a manpower pool of highly specialized scientific and technical personnel whose training is subsidized by educational institutions. The argument of "parity" in terms of manpower training subsidized by the government has not yet surfaced in the geothermal industry. However, industry spokesmen have strongly argued for "parity" with the oil and gas industries in such areas as tax policy and depletion allowances. Therefore, as the industry grows, the need for specialized manpower may shift it to a higher priority. A modest training program at the appropriate institution(s) would go a long way toward removing current and potential scarcities of specialized personnel that could constrain industry growth.

\section{Secondary Problem Occupations}

The following occupations did not appear to be viewed by the respondents as a widespread problem. Instead, they were more unique to a single firm or to a specific locale. However, they are included here for purposes of completeness and future reference.

Mechanical and Electrical Engineers. These personnel are hired at the B.S. level and given the necessary geothermal training on the job. The training is oriented toward drilling, geological, geochemical, and hydrological characteristics applicable to the geothermal resource.

Control Operator. This position requires an ability to operate steam geothermal components and transmission systems. Training is on-thejob and selection for the positions is via very careful in-house screening.

Economics and Finance Personnel. An understanding of the resource and its utilization and unique features is necessary. The general requirement is an M.B.A. coupled with an understanding of geology and energy.

Pipeline Velders. Recruitment is generally through trade schools or advertising in local newspapers. On-the-job training is used to develop skills. The problem (In Southern Utah) has been a shortage of welders certified for pipeline construction. 
Heavy Equipment Operators. Recruitment has been difficult in areas where exploration activities have fluctuated considerably making it impossible to guarantee work for extended periods of time. These personnel are also locally recruited in areas near the development sites.

Pipefitters, Hectricians, Iron Workers. Problems in recruitment are limited to The Geysers area and result from competition with other local industries and a limited labor pool at a remote site.

No policy initiatives are recommended for the above occupations because of the relatively isolated nature of their occurrence. The large firms involved at sites with long-run development activities should be allowed to devote their own resources to the problems. In the cases where smaller firms experience recruitment and retention problems the issue appears to be basically the disagreeable nature of the work. The area in which government action might be of help is in streamlining the permit granting procedures and other regulatory processes in order to facilitate better planning for continuous activities. This issue is treated by several other studies and will not be pursued here. 5

\section{New and Emerging Occupations}

Ten firms responded to the subject of new and emerging occupations. As might be expected, many of the occupations discussed have already been identified as posing recruitment and retention problems. Most occupations listed are of a scientific and technical nature. They are also mostly traditional occupations that are becoming specialized to geothermal activities.

Geologists. One area of specialization is in exploration of igneous formations and another is in petrology mapping abilities. Areas of university training that would be helpful are structural volcanic rocks and in spatial relationships of geothermal aquifers.

Geochemists. Specialists are emerging with a background in thermal fluids and other areas of groundwater study.

5For example, see Gene V. Beeland, et al., "Geothermal Development on Federal Lands - The Impediments and Potential Solutions," a report prepared for the Department of Energy - Division of Geothermal Energy, January 1978. 
Geophysicists. Needed area of training is hard rocks.

Reservoir Engineers. One specialized area still in its infancy is the design of reservoir facilities. Another is in shallow hole engineering. The position basically will be a hydrologist with a background in geology to help in understanding structural and spatial characteristics of the resource.

Civil, Mechanical, and Electrical Engineers. The specialization is the capability to design and monitor systems for waste disposal, emission control, and reinjection.

Chemical Technicians. Skills are composed of the combined areas of hydrology and brine chemistry.

Geothermal Financial Comptroller. There is a need emerging in the geothermal area for individuals well versed in geophysics or geology with an advanced degree in finance (M.B.A.). Peculiarities in the development of geothermal resources (e.g., contracting for the sale of steam and time delays from leasing to reservoir development) have created a new financlal and investment framework which requires this type of expertise.

Drilling Personnel. The emphasis on drilling occupations lies in the needed abilities to deal with abrasive rock formations and high temperatures. These conditions have led to technical modifications such as in the fluid medium.

Land Managers. The need for individuals in this area is in part derived from increased government regulation.

Reports Coordinator. Duties are to compile and review regulatory reports. Requirements are a combination of joumalistic and technical expertise. This new position is a result of increasing regulatory requirements.

Technical Reports Analyst. Requirements are basically the same as those for a reports coordinator in that the impetus for this new occupation is also being created by regulatory requirements. Recruitment for both positions is through college campus interviews and press advertisements. 


\section{Projection Information and Occupational Profiles}

A total of sixteen firms provided information which could be used to construct a forecasting model and to develop occupational profiles. Most of the information applies to only a limited number of sites -- especially Roosevelt Hot Springs, The Geysers, Niland, Brawley, and East Mesa. A total of thirty firms supplied data on the quantity of manpower employed in each occupation and yearly replacement needs. Some firms supplied data for 1978 rather than 1977, and these differences are noted in the analyses.

Exploration and Appraisal of the Resource

This activity may be subdivided into two categories denoting the intensity of the efforts involved. First is the "casual use" which is defined by the Bureau of Land Management (Code of Federal Regulations CFR, Title 43 , 3209.0-5(d) as ". . activities that involve practices that do not ordinarily lead to any appreciable disturbance or damage to lands, resources and improvements. For example, activities which do not involve the use of heavy equipment or explosives." These activities include aerial photo surveys, geochemical and micro-gas surveys, stratigraphic, lithologic, and structural mapping. ${ }^{6}$ The second category is the use of more intensive exploration techniques -e.g., geophysical surveys which include the drilling of shallow temperature holes, or the use of heavy equipment to construct temporary access roads.

A variety of firms with different types of manpower is required in the exploration and appraisal activity. This resulted in considerable variance in the estimates provided by different firms in the survey. Seven firms addressed themselves to a question pertaining to the estimated number of person months necessary to explore and appraise the resource to the extent that a decision can be made to develop the reservoir at a given site or to abandon development plans. Estimates ranged from three person months to three hundred and sixty person months, depending on the particular phase of activity with which the firm was involved. However, two key firms which were involved in all phases of the exploration and appraisal activity estimated that the total amount of manpower required was 300-360 person months in order to explore and appraise the resource to the exterit that a decision could be

6U.S. Department of Interior, U.S. Fish and Wildlife Service, Geothermal Project: Geothermal Handbook (June 1976), p. 136. 
made to develop the resource at a given site or to abandon development plans. This appears to be the most representative estimate since the smaller estimates of other firms reflected their limited role of involvement (e.g., drilling, seismic, and electrical surveys). As will be seen in the next section on drilling, any single estimate to be applied to the industry is highly tenuous because of the different types of energy conversion systems that have to be fitted to the site specific nature of the resource.

The estimate of manpower requirements given in this study is somewhat lower than the 1974 Project Independence estimate.? However, the latter was based on a differently structured set of assumptions (centered on a $200 \mathrm{MW}_{\mathrm{e}}$ plan based on the brine resource) in order to create building block estimates. The sections of the report which are pertinent to the discussion on occupational structure, occupational requirements, and projections are reproduced in the appendix.

The total number of person months estimated by the Project Independence report as required to explore and appraise the resource (specific assumptions on page D-4) for a $200 \mathrm{MW}$ e plant was 696 (for two years). However, this included drilling ( 288 person months), and once this activity is subtracted, the residual is 408 person months. 8 since current plants (or those expected in the near future) are no larger than $135 \mathrm{MWe}_{e}$ to $160 \mathrm{MW}$ and since it is reasonable to assume some efficiencies in resource exploration and assessment have been gained in the last few years, the estimate appears quite compatable with that given in Project Independence. However, the reader should understand that the estimate is based on current and recent experience of firms while the Project Independence estimate is based on a rigid set of assumptions geared to forecasting the future far beyond our time horizon.

7U.s. Federal Energy Administration, Project Independence Blueprint, Final Task Force Report, Geothermal Energy (November 1974). See pages $\bar{D}-1$ through D-8.

8t may be somewhat misleading to separate the arilling activity because it. is specificajly exploratory drilling. Reconsideration of the phrasing of our request leaves the distinction between exploratory and production drilling quite ambiguous. Fortunately, there are a number of references to drilling requirements, and these will be discussed in the next section. 
Occupational Profile

Table 12 provides a list of occupations and the quantity of persons required on which the Project Independence estimate was based. It is presented for comparison with the survey results for occupational structure only. The quantities of manpower are not comparable because the Project Independence estimate is geared toward completing an activity while the present study is geared toward employment by year for given firms. Also, it is believed that the Project Independence occupational list is the most comprehensive for comparison purposes.

TABLE 12. OCCUPATIONAL PROFILE FROM PROJECT TNDEPENDENCE EXPIORATION AND APPRATSAL OF THE RESOURCE

\begin{tabular}{lc}
\hline \multicolumn{1}{c}{ Skill } & $\begin{array}{c}\text { Quantity } \\
\text { Required }\end{array}$ \\
\hline Geologist & 3 \\
Geophysicist & 2 \\
Landman & 2 \\
Drill Rig Foreman & 4 \\
Driller & 12 \\
Laborer & 8 \\
Truck Driver & 4 \\
Geochemist & 2 \\
\hline
\end{tabular}

It should be pointed out that many of the occupations which appear on the occupational list in this study as research exploration and assessment appear under the Project Independence heading of reservoir design and development. However, there are other reasons for differences in occupational ilstings. First, this is simply an aggregation of the occupations from the several firms interviewed. Therefore, some of the occupations may be considered more of a peripheral nature (derived from the activity but not requiring physical presence at the site). Second, growth of the industry and of the individual firms has led to more occupational specialization. Third, government regulatory requirements have created the need for certain types of expertise (e.g., environmental technicians). The fourth factor is the evolution of technology. The fifth reason is in part a reflection of the previous four but is slightly 
more abstract. In effect, preliminary investigation (here and elsewhere) hints at a common theme (though as yet quite undefined and not thoroughly explored) in the evolution of occupational structures in energy related industries. The need for research in this area is discussed in Chapter 7 , Recommendations, and need not be repeated here.

Table 13 lists the occupations derived from the survey results. (Occupational lists with the number employed in each position in the survey can be found in the appendix.) This pattern will also be repeated as the data permits in the other activities.

TABLE 13. COMBINED LIST OF OCCUPATIONS OR OGCUPATIONAL GROUPS TNVOLVED IN RASOURCE EXPIORATION AND APPRAISAI

Geologist

Geophysicist

Geochemist

Mechanfcal Engineer

Drilling Ingineer

Petroleum Engineer

Engineering Technician

Computer Analyst

Data Processing

Contracting/Purchasing

Financial Analyst

Secretarial:
Accounting

Legal

Bookkreeper

Manager

Land Manager.

Land Draftsman

Land Secretary

Draftsman

Drilling Supervisor

Exploration Technician

Environmental Technician

Reservoir Design and Development

This activity may include additional deep well exploratory drilling, but most drilling is geared toward production and reinjection wells. Also, surface structures such as steam gathering systems are included.

$9_{A}$ Iimited descriptive Investigation can be found in U.S. Department of Labor, Bureau of Labor Statistics, Bulletin 2005, Technological Change and Its Labor Impact in Five Energy Industries (April 1979). 
Number of Kells Required to Prove Feasibility of Energy Production

The number, depth, and frequency of replacement for the wells necessary to prove a reservoir for scheduled energy production or other activity is ambiguous, yet vital to any estimate of manpower requirements. Nine firms responded to this issue. One firm alleged that only one well was required to prove a hot dry rock reservoir. Little can be said about the additional drilling needed to develop the hot dry rock resource because this type of geothermal system is still in the early experimental stages. Other firms responded that for some reservoirs at The Geysers only two to three wells were required. This is consistent with the estimate given (one to five deep exploratory wells) in the Geothermal Projects Geothermal Handbook ${ }^{10}$ (page 142). Additional estimates provided by the Handbook are that a crew of four to six is required for ten days of drilling per well of approzimately 10,000 feet in depth (page 142). The Handbook assesses the drilling rate for geothermal wells to be between 100 to 200 feet per 24 hour day (page 22). Finally, it should be pointed out that drilling depths in many cases are not reflective of what is required to tap the resource but what is economically feasible. For example, depths of 12,000 to 15,000 feet are estimated to be required to reach the geopressured resource, but the maximum explorable depth is approximately 11,000 feet (1976 estimate given by the Geothermal Handbook, page 2I).

Another document which provides estimates pertaining only to The Geysers estimated test drilling to require 45 to 60 days. 11 . Host wells at The Geysers were assessed at depths of 7,000 to 8,000 feet. The Consultant Report stated that 10 to 15 wells were required to support a $110 \mathrm{MW}$ plant (page I-C-14), with as many as 25 wells required when reserve and reinjection wells are counted. Ninety percent of the wells drilled were said to be successful, with the remainder used for reinjection (page IV-D-2).

10 See footnote $\# 5$.

11Califormia Energy Resources Conservation and Development Commission, Consultant Report on Environmental Analysis for Geothermal Energy Development in the Geysers Region, Volume II, Master Environmental Assessment, prepared by Stanford Research Institute (May 1977), P. I-G-5: A later description of a drilling rig crew is that it consists of four drilling company employees and eight others either from local unions or transient roustabouts $(p, V-D-6)$. 
One firm estimated the average number of production wells required to support a $55 \mathrm{MW}$ e power plant to be eleven plus two reinjection wells and three reserve wells. This firm did not provide average depth estimates. Four other firms estimated the average number of wells necessary to prove a reservoir for production to be respectively -- 14, 8-10, 11, and 10. Replacement wells were estimated to be required every one to three or one to five years by these firms. Each of the latter four firms provided estimates based on their experience at The Geysers, while the estimate provided by the first firm for a $55 \mathrm{MW}$ plant was considered an average of different sites with which the firm was involved. Average well depths were reported by seven firms and ranged from 3,400 feet to 14,000 feet. Given the variety reported, projections of manpower requirements had to be based on judgments from interviews and observations.

\section{Occupational Profile for Drilling Firm}

Table 14 gives the occupational profile for production drilling from Project Independence for a $200 \mathrm{MW}$ dry steam plant, assuming 34 wells (providing 20 percent spare capacity), 60 work days per well (average), five rigs, and an average depth of 5,000 feet.

TABLE 14. OCCUPATIONAL PROFTIE FROM PROJECT INDEPENDENCE (DRTLING PERSONNEH)

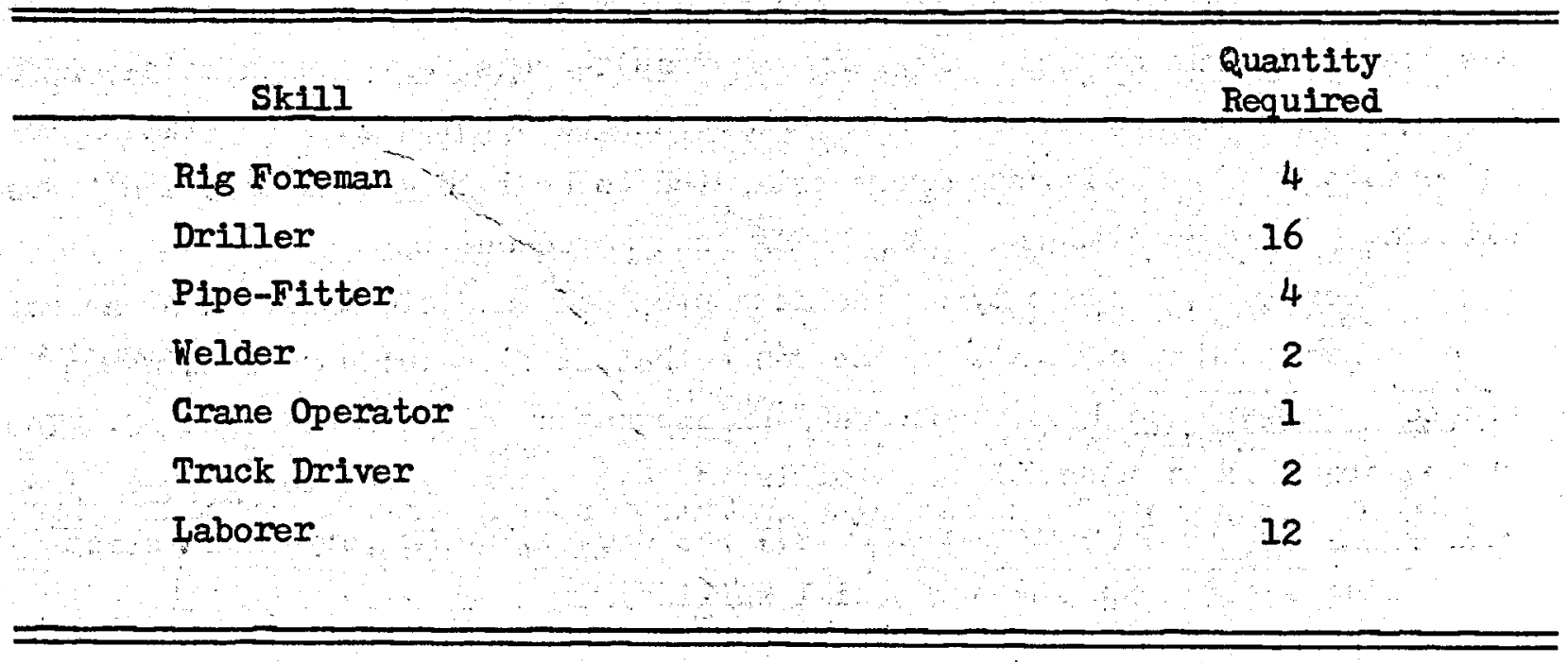


f

The occupational profile obtained in this study is presented in Table 15. Note that the requirements in this study are geared toward continuous operations instead of determining the needs for obtaining a specific objective as in Table 14. Three firms provided information in this category. No new types of personnel were needed for geothermal drilling.

TABLE 15. OCCUPATIONAL PROFIIE FROM PERSONAL INTERV IEWS

\begin{tabular}{cc}
\hline Skill & $\begin{array}{c}\text { Quantity } \\
\text { Required }\end{array}$ \\
\hline Assistant Driller & 8 \\
Driller & 4 \\
Drilling Foreman & 4 \\
Derrickman & 4 \\
Motorman & 4 \\
\hline
\end{tabular}

Manpower Requirements for the Reservoir Feed System

Five firms provided estimates of the number of person months required to construct the reservoir feed system and the average number of person months required to operate and maintain the reservoir feed systems for one year. The only useful information provided concerning the construction of a feed system was that, as a rule of thumb, the manpower requirements were approximately 25 percent of the total requirements for constructing a power plant. Operation requirements of the feed system were estImated to be 1 to 4 full time individuals with some major maintenance tasks being contracted out.

Despite the sparsity of the data provided, the information does appear to have been rather accurate in the sense that it fits quite well into the Project Independence list of occupations and number of persons required. The survey provided no occupational profile in this category but the project Independence profiles (Tables 16 and 17), based on a $200 \mathrm{MW}$ dry-steali plant (including design requirements), will suffice. 
TABLE 16. OCCUPATIONAL PROFIIE FROM PROJEGT INDEPENDENCE, CONSTRƯCTION OF GATHER ING SYSTEM

\begin{tabular}{lc}
\hline Skill & $\begin{array}{c}\text { Quantity } \\
\text { Required }\end{array}$ \\
\hline Mechanical Engineer (Design) & 2 \\
Civil Engineer (Design) & 1 \\
Draftsman (Designer Quality) & 1 \\
Draftsman & 1 \\
Route Surveyor & 5 \\
Civil Engineer (Construction) & 1 \\
Foreman & 2 \\
Welder & 4 \\
Carpenter & 2 \\
Concrete Worker & 4 \\
Dozer-Operator & 2 \\
Truck Driver & 4 \\
Crane Operator & 2 \\
Insulation Installer & 6 \\
Inspector (Construction) & 1 \\
Inspector (Testing) & 2 \\
\hline
\end{tabular}

Source: See footnote 7 .

TABLE 17.. OCCUPATIONAL PROF IIE FROM PROJECT TNDEPENDENCE, OPERATION AND MAINTENANGE OF GATHERING SYSTEM

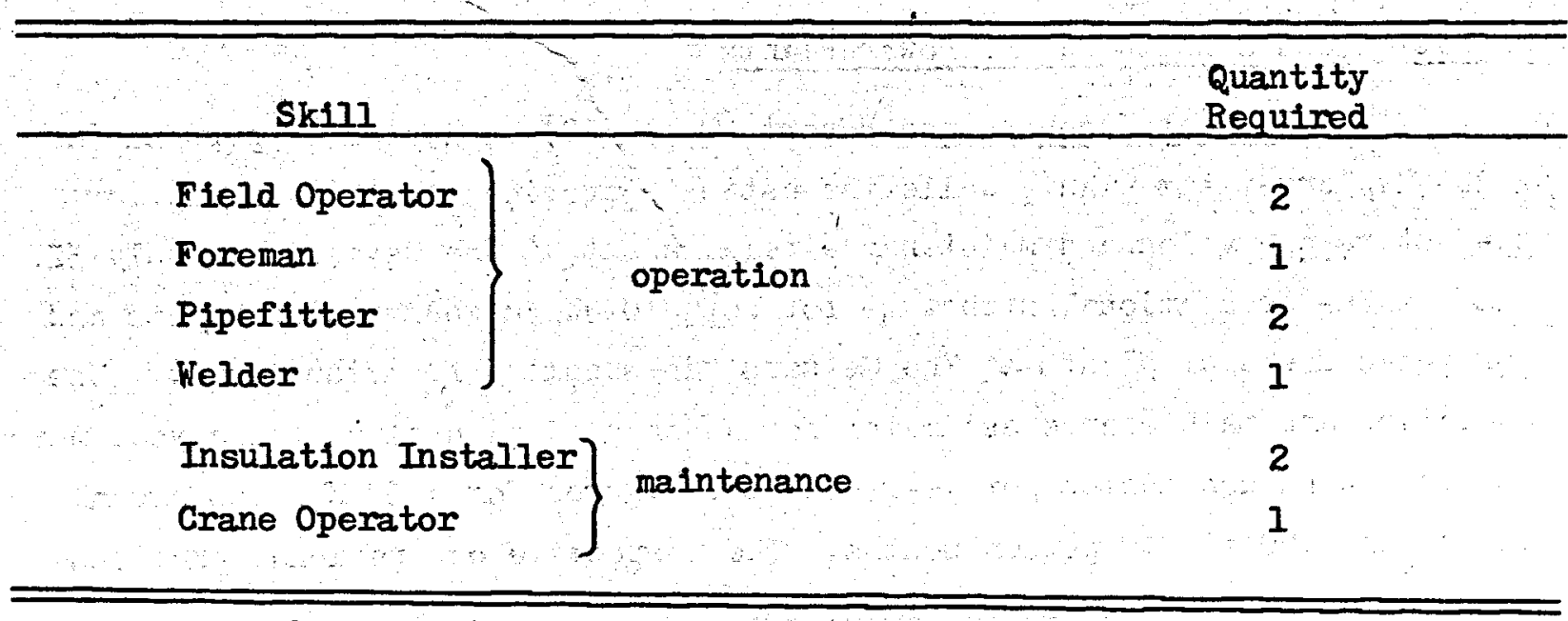

Source: See footnote 7 . 


\section{Construction of Power Plants}

Seven firms provided estimates of the number of person months required for power plant construction and/or direct use facility construction and the average number of person months required to operate and maintain the facility for one year. The manpower needs for construction of a $10 \mathrm{MW}_{\mathrm{e}}$ demonstration plant were estimated to be 35 to 40 persons for ten months. Estimated requirements for construction of $50 \mathrm{MW}$ plants ranged from 2;400 to 4,800 person months. The wide variance in manpower requirements could partially reflect the more intensive efforts needed to commercialize the geothermal resource as it is used in its more marginal (i.e., less productive) forms, especially in the transition from dry steam to hot water. The survey did not include the construction of transmission 1ines. However, the Consultant Report (p. I-F-3 and I-F-5) stated, "construction of the transmission lines for one generating unit [at The Geysers] requires about 8 months . . The transmission line crews vary from 10 to 30 workers and are drawn from PG \& E's Iine Construction Department." Again, the 2,400 to 4,800 estimate proves to be compatible with the Project Independence estimate ( 3,882 person months) based on a three year phased construction program. Table 18 gives the requirements as estimated in Project Independence.

Three occupational profiles (reproduced in appendix) pertaining to power plants which were gathered from the personal interview survey are a mixed result, because the firms were involved in various stages of reservoir completion, power plant design, and engineering. However, one profile is more representative of occupations required for construction activities, and it is reproduced in Table 19.

\section{Operation and Maintenance of Power Plants}

The Project Independence report (Table 20) estimates 41 persons for a $200 \mathrm{MW}_{\mathrm{e}} \mathrm{dry}$-steam plant, while the estimate provided to this survey for the entire operation and maintenance requirement at The Geysers was only 52.

The occupational structure for both $10 \mathrm{MW}_{e}$ demonstration plants and for the commercial plants at The Geysers was supplied from the survey. The operation and maintenance estimates for a demonstration plant for a year were 224 to 300 person months per year, and the figures for a $50 \mathrm{Mw}$ commercial

plant were 100 to 360 person months. The respective occupational profiles are reproduced in Table 21 and Table 22. 
TABLE 18. OCCUPATIONAL PROF IIE FROM PROJECT INDEPENDENCE, DESIGN AND CONSTRUCTION OF POWER PLANT

\section{Power-house:}

Assume: a) 2-100 $\mathrm{MW}$ (net) Generating Units

b) 1.5 year design schedule

c) 3 year construction schedule

d) 24 month delivery schedule on each $\mathrm{T} / \mathrm{S}$ set

Skilled Personnel

Quantity Required

Structural Engineer

Mechanical Engineer

Civil Engineer

Electrical Engineer

Corrosion Engineer

Architect

Draftsman (Designer Quality)

2

Draftsman

Topog. Surveyor

Purchasing Agent

Inspector (Equipment)

Corrosion Engineer

Civil Engineer (Construction)

Mechanical Engineer

Electrical Engineer

Surveyor (Construction control)

Inspector (Construction)

Superintendent (Construction)

Assistant Superintendent (Construction)

Foreman

Electrician

Pipe Fitter

Welder

Millwright

Iron-Worker

Concrete Worker

Sheetmetal Worker

Carpenter

Plumber

Insulation Installer

Tile-Setter

Painter

Instrument Technician

Machinist

Rigger

Truck Driver

Crane Operator

Timekeeper

Warehouseman

Pile-Driver

Laborer Common

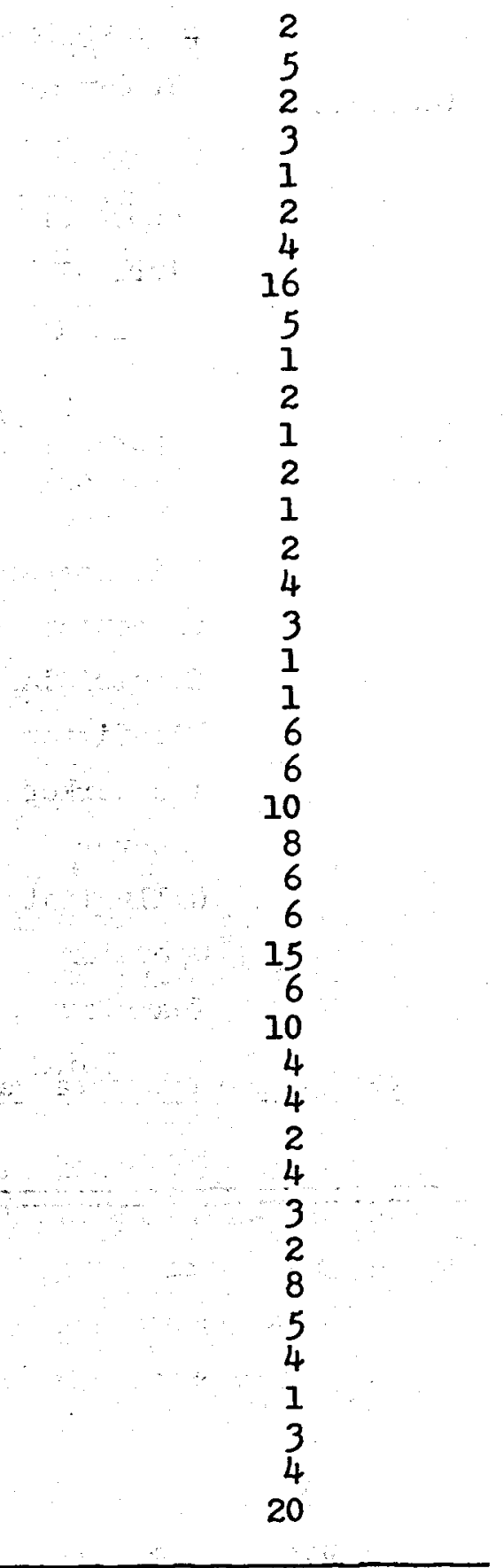


TABLE 19. OCGUPATIONAL PROFIIE FOR CONSTRUCTION ACTIVITIES FOR COMMERCIAL POWER PLANTS (APPROXIMATELY $50 \mathrm{NW}_{\mathrm{e}}$ )

AS IRAWN FROM PERSONAL INTERVIEWS

(Includes multiple plant activities at The Geysers)

\begin{tabular}{|c|c|c|c|c|}
\hline $\begin{array}{l}\text { Identi- } \\
\text { fication } \\
\text { Number } \\
\end{array}$ & $\begin{array}{l}\text { Occupations } \\
\text { Most Strongly } \\
\text { Related to } \\
\text { Geothermal } \\
\text { Activities } \\
\end{array}$ & $\begin{array}{c}\text { Total Number } \\
\text { of Persons } \\
\text { Employed Sept. } \\
1977\end{array}$ & $\begin{array}{c}\text { Total Number } \\
\text { of Person } \\
\text { Months Sept. } \\
1977\end{array}$ & $\begin{array}{c}\text { Yearly } \\
\text { Replace- } \\
\text { ment Needs }\end{array}$ \\
\hline \multirow[t]{5}{*}{$\begin{array}{l}26 \\
\text { (operator) }\end{array}$} & $\begin{array}{l}\text { Project } \\
\text { Superintendent }\end{array}$ & 1 & 12 & 0 \\
\hline & Engineer & 27 & 227 & 4 \\
\hline & Inspector & 12 & 155 & 2 \\
\hline & Clerical & 16 & 185 & $\underline{2}$ \\
\hline & Total & 50 & 579 & 8 \\
\hline \multirow[t]{11}{*}{$\begin{array}{l}\text { (con- } \\
\text { tractors) }\end{array}$} & $\begin{array}{l}\text { Superintendent } \\
\text { Clerical, } \\
\text { Bngineer }\end{array}$ & 10 & 65 & - \\
\hline & Boilermaker & 2 & 2 & - \\
\hline & Carpenter & 50 & 169 & - \\
\hline & Electrician & 15 & 62 & - \\
\hline & Pipefitter & 5 & 18 & - \\
\hline & Ironworker & 10 & 38 & - \\
\hline & Laborer & 22 & 163 & - \\
\hline & Millwright & 2 & 6 & - \\
\hline & Operator & 27 & 227 & - \\
\hline & Teamster & $\underline{8}$ & 38 & $=$ \\
\hline & Total & 151 & 723 & - \\
\hline
\end{tabular}


TABLE 20. OCCUPATIONAI PROFIIE FROM PROJECT INDEPENDENCE, OPERATION AND MATNTENANCE OF POWER PLANTS

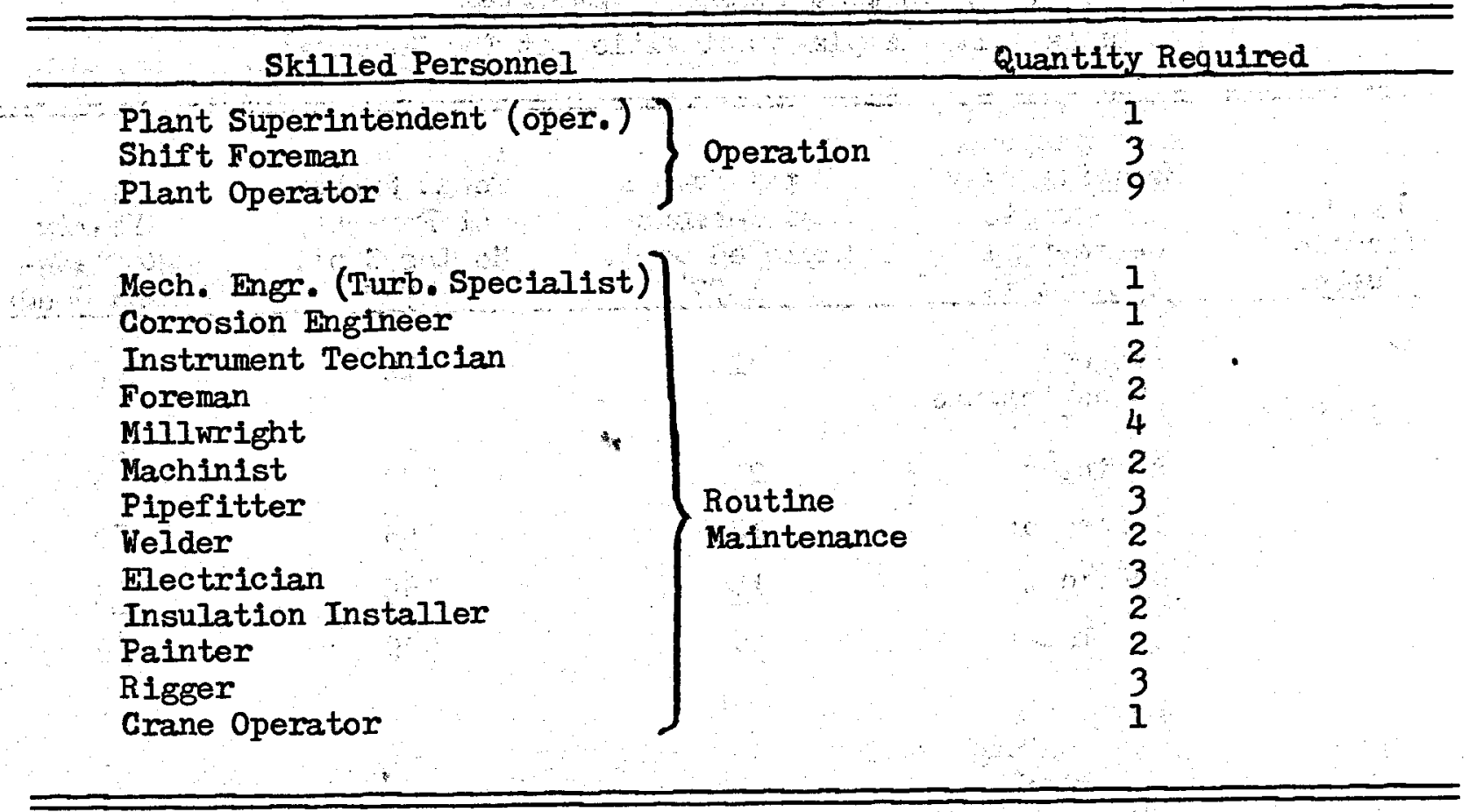

TABLE 21. OCCUPATIONAL PROF IIE FOR THE OPERATION AND MAINTENANCE OF A $10 \mathrm{MW}_{e}$ DEMONSTRATION PLANT

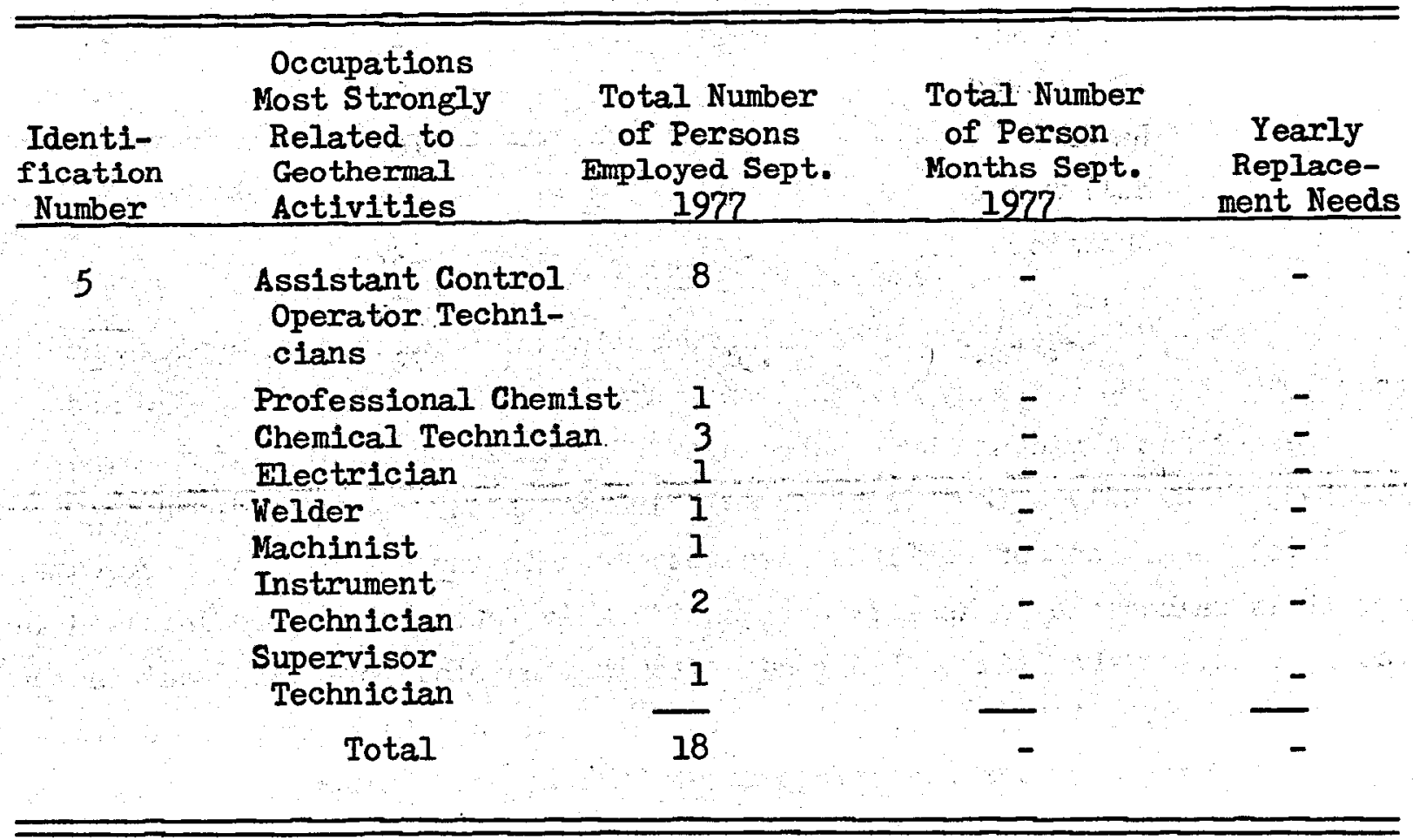


TABLE 22. OCCUPATIONAL PROFTIE FOR OPGRATION AND MATNTENANCE OF A COMMERCIAL POWER PLANT

(Includes multiple plant activities at The Geysers)

\begin{tabular}{|c|c|c|c|c|}
\hline $\begin{array}{l}\text { Identi- } \\
\text { fication } \\
\text { Number } \\
\end{array}$ & $\begin{array}{l}\text { Occupations } \\
\text { Most Strongly } \\
\text { Related to } \\
\text { Geothermal } \\
\text { Activities } \\
\end{array}$ & $\begin{array}{c}\text { Total Number } \\
\text { of Persons } \\
\text { Employed Sept. } \\
1977\end{array}$ & $\begin{array}{c}\text { Total Number } \\
\text { of Person } \\
\text { Months Sept. } \\
1972\end{array}$ & $\begin{array}{c}\text { Yearly } \\
\text { Replace- } \\
\text { ment Needs } \\
\end{array}$ \\
\hline \multirow[t]{4}{*}{26} & Machinist & 11 & - & 1 \\
\hline & - Electrician & 8 & - & - \\
\hline & $\begin{array}{l}\text { Instrument } \\
\text { Repairman }\end{array}$ & 4 & - & - \\
\hline & Welder & 2 & - & - \\
\hline \multirow{7}{*}{ 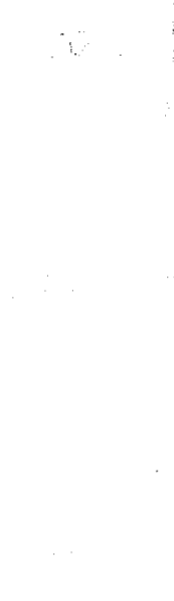 } & Rigger & 2 & - & - \\
\hline & Helper & 6 & - & 1 \\
\hline & $\begin{array}{l}\text { Control } \\
\text { Technician }\end{array}$ & 1 & - & - \\
\hline & $\begin{array}{l}\text { Senior Power } \\
\text { Plant Operator }\end{array}$ & 2 & - & - \\
\hline & $\begin{array}{l}\text { Power Plant } \\
\text { Operator }\end{array}$ & 12 & - & - \\
\hline & $\begin{array}{l}\text { Assistant Power } \\
\text { Plant Operator }\end{array}$ & 4 & $=$ & $=$ \\
\hline & Total & 52 & - & 2 \\
\hline
\end{tabular}

Total Employment Trends

Table 23 supplies trends and projections for geothermal employment from 1970 to 1985 for many of the firms surveyed. Growth between 1970 and the present has obviously been substantial. Totals could not be estimated for 1985 since only a few firms were willing to speculate beyond 1980 . A relatively small number of firms also responded to the request for 1970 data, but it is reasonable to assert that considerably fewer firms were involved in the industry at that time. Table 24 presents the totals of employment in the four years (1970, 1975, 1980, 1985) with the data for the nonrequested years being deleted ( $n=$ number of firms responding in this colum). 
TABLE 23. ESTMMATE OF TOTAL GEOTHERMAL EMPLOYMENT (NUMBER OF PERSONS)

AND THE PERCENT OF GEOTHERMAL TO TOTAL EMIPLOYMENT, BY YEAR*

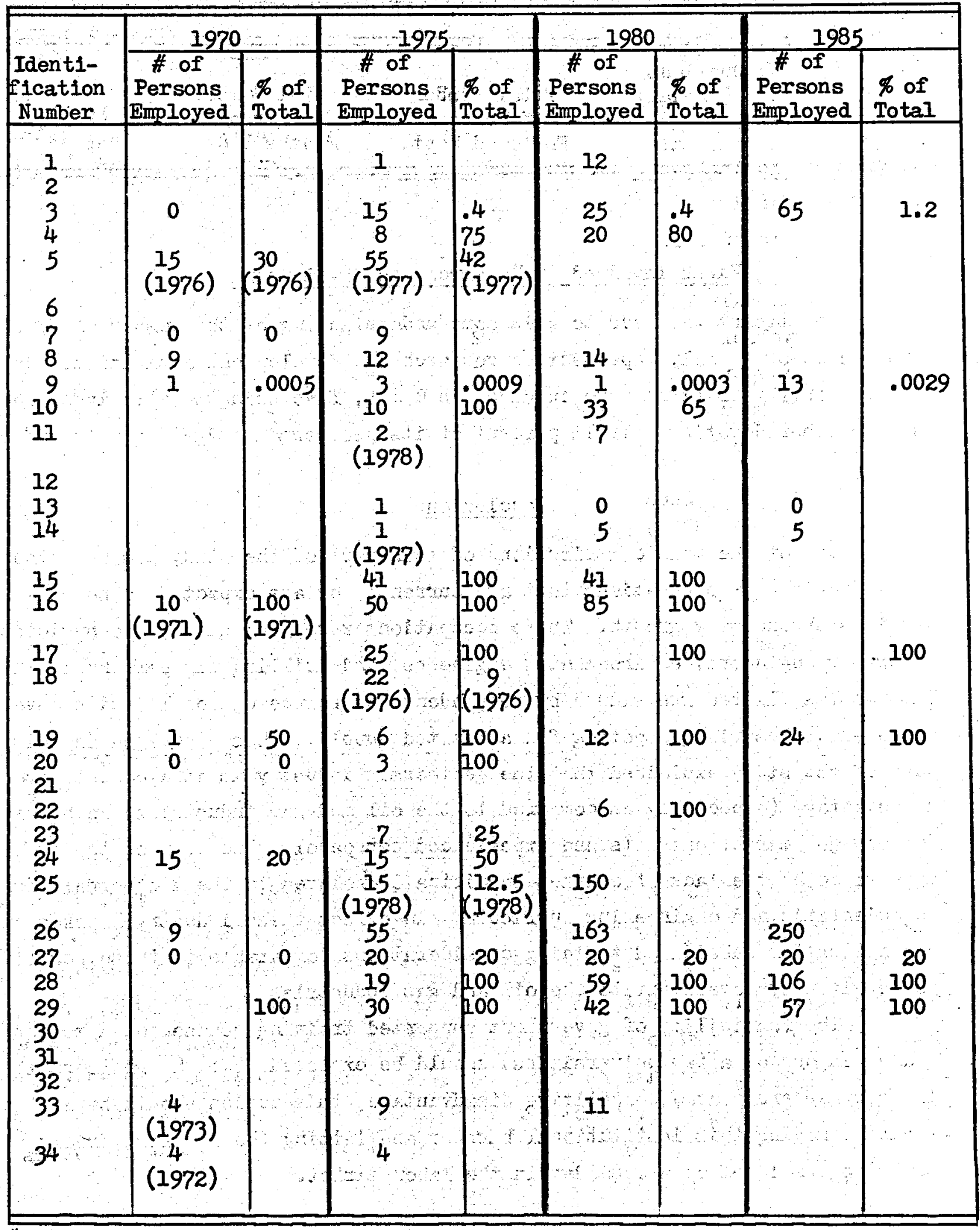

* Blank spaces indicate that no information was provided. 
TABLE 24; TOTAL NUMBER OF PERSONS EMPLOYED IN GEOTHERMAL ACTTV TTIES (excluding data pertaining to nonrequested years)

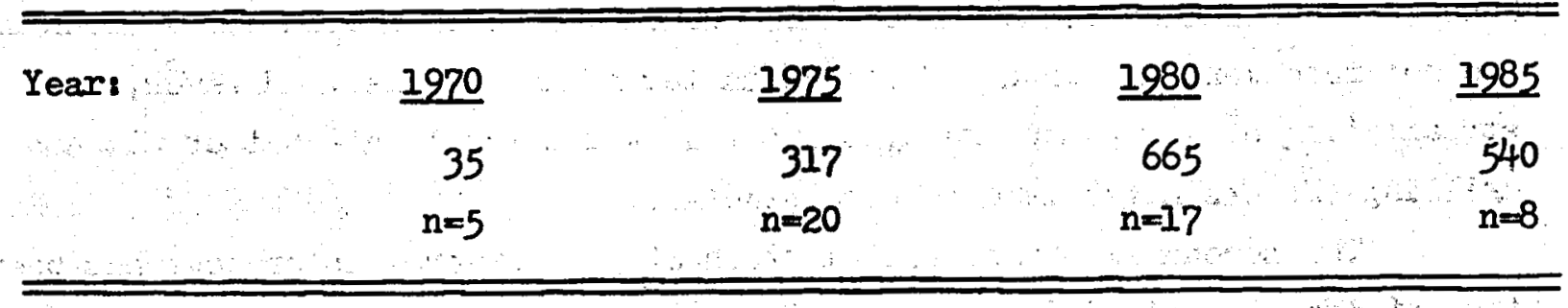

Firms Involved in Research and Development

An attempt was made to gain some understanding of the number of firms involved in or totally dependent on research and development activities. Only six of thirty-four firms were involved in $R$ \& $D$, five being totally involved and the other devoting only 15 percent of 1ts geothermal budget to this effort.

\section{Conclusion}

One of the main contributions of this part of the study has been the identification of occupations that are currently or are expected to be constraints on industry rowth. These occupations were geologists, geophysicists, reservoir engineers, environmental engineers, and drilling rig personnel. All but the last listed are viewed by respondents as scarce nationally with several different industries competing for a limited supply. Those surveyed in this part of the study explained that the geothermal industry is at a competitive disadvantage (especially as compared to the oil and gas industries) in bidding for new job market entrants and experienced personnel. The crux of the problem appears to be the lack of courses specifically related to the geothermal resource in scientific and engineering curricula. In effect these industry "spokesmen" are asking for subsidized training considerations comparable to those perceived to be given by government to the oil and gas industries.

The feasibility of government supported training courses on a modest scale (in one or a few universities) should be explored. If the geothermal industry is truly at a competitive disadvantage, this action should be a step toward removing this institutional barrier and letting the industry freely seek its own level as a demander in the labor market. 
The last occupational group, ydiling personnel, has widespread problems (e.g., high turnover) due to the nature of the job (e.g., extended hours, frequent travel, and remote work sites): Direct government actions are not recommended because of the character of the problem. However, a streamlining of government regulations that would facilitate better planned drilling efforts might lead to more stability.

The second important contribution of the personal interviews has been the information gained for manpower forecasting purposes. This was used extensively in the formulation of a forecasting model which is discussed in the next section. 
$\cup$ 
Chapter 4

\section{MANPOWER FORECAST}

\section{Introduction}

Based on the information obtained from the personal interview phase of the manpower assessment study and upon the other sources available, the following procedure was used to forecast manpower growth in the geothermal industry. Note that this forecast is only for that segment of the industry which encompasses electrical energy production. To date the direct use geothermal activities are largely undefined. This may be a serious shortcoming in assessing the industry's growth and potential uses since direct use is the most efficient application of the resource. Therefore, a crude employment multiplier for that segment of the industry which is not engaged in commercial production of electicicity was developed for this study. Despite the uncertainties that attend the forecast and the application of the multiplier, such a step is necessary in the development of a clearer picture of this relatively unknown segment of the industry.

\section{Geothermal Electrical Energy Growth Scenario}

The first task was to Identify the most Iikely growth scenario for the geothermal industry. Forecasted potential growth in the industry has drasticaily declined from the highly optimistic extremes of a few years ago. Figure 12 on the next page demonstrates this point. As time has passed, more realism has been brought into the assessments and expectations of the resource. Although the more recent estimates are more compatible with each other than earlier ones, differences may still be in the neighborhood of several hundred megawatts. Given the small base of industry output ( $0 . g_{.}$, $502 \mathrm{MWe}_{\mathrm{e}}$ in 1977) as a point of reference, it is obvious that differences of a magnitude of several hundred megawatts are considerable in percentage terms and would affect manpower estimates accordingly. 
FIGURE 12. ESTTMATES OF MW TO BE GENERATED FROM GEOTHERMAL RESOURCES

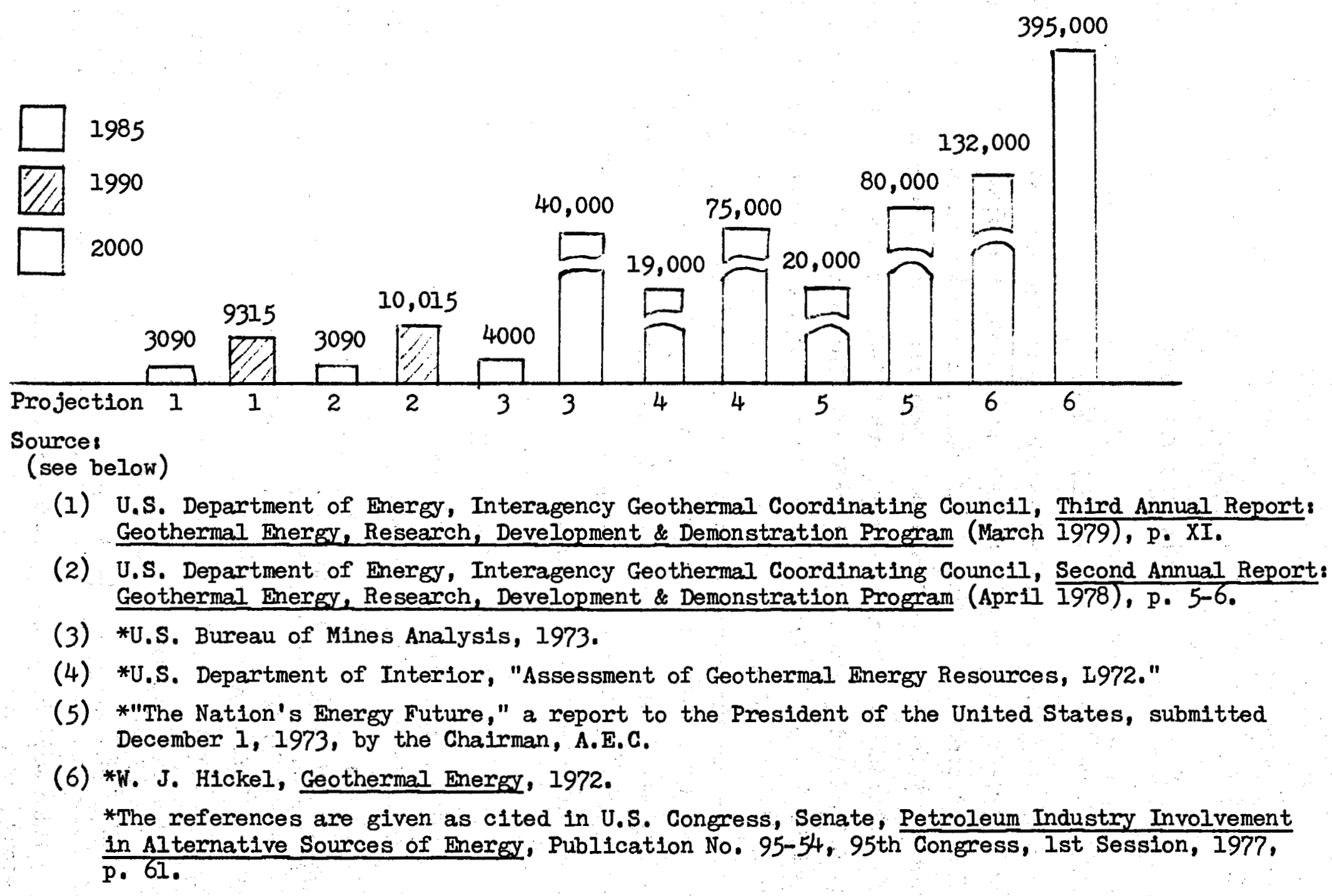

(1) U.S. Department of Energy, Interagency Geothermal Coordinating Council, Third Annual Report: Geothermal Energy, Research, Development \& Demonstration Program (March 1979), p. XI.

2) U.S. Department of Energy, Interagency Geothermal Coordinating Council, Second Annual Report: Geothermal Energy, Research, Development \& Demonstration Program (April 1978), p. 5-6.

W.S. Department of Intertor, "Assessment of Geothermal mergy Resources, L972." December 1, 1973, by the Chairman, A.E.C.

(6) *w. J. Hickel, Geothermal Energy, 1972.

The references are given as cited in U.S. Congress, Sen p. 61 . 
Most sources have forecasted no additional commercial production except at The Geysers until 1983. ${ }^{12}$ However, there is disagreement as to how much power will come on line at The Geysers during 1979, 1980, 1981, and 1982. The installed capacity was $502 \mathrm{MW}_{e}$ at The Geysers in 1977, approximately 608 $\mathrm{MW}_{\mathrm{e}}$ in 1978, and approximately $908 \mathrm{MW}$ by the end of 1979. The best estimate through 1980 is considered to be 971 MWe based on information released by the California Energy Commission, and the best estimate for 1981 is considered to be $1301 \mathrm{MW}_{e}{ }^{13}$ These estinates appear to be more reasonable than $1288 \mathrm{MW}$ and $1453 \mathrm{MW}_{\mathrm{e}}$ for 1980 and 1981, respectively, which were given by the Energy Research and Development Agency, Division of Geothermal Energy. 14 The rationale for this conclusion is that the latter overestimated The Geyser's output by approximately $165 \mathrm{MW}$ for 1978 and approximately $105 \mathrm{MW}$ for 1979. Estimates have been updated in 1978 and 1979 reports by the Department of Energy's Interagency Geothermal Coordinating Council (ICCC), but the forecasts begin with the year 1983. ${ }^{15}$ This required the use of the other sources thus far mentioned. The IGCC's scenario (as used in the 1979 report) is used beginning with 1982 (when $1680 \mathrm{MW}$ are forecast for The Geysers) and progressing through 1990. Although there are other (differing) estimates of industry growth, they are not as specific as that of the IGCC. Also, as the uncertainties increase with further and further projecting into the future, the evaluation of the underlying assumptions that lead to differing estimates also becomes more tenuous. The qualifications that can be made are that other estimates are

12 An exception is given by hobert Rex, who projects installed capacity at The Geysers to be 1733 MW by the end of 1983 and additional installed capacity to be $138 \mathrm{NW}$ at Imperial Valley and $50 \mathrm{MW}_{e}$ at Roosevelt Hot Springs, Utah, for the same year. See Robert W. Rex, "The U.S. Geothermal Industry in 1978," paper presented at the Geothermal Resource Counc1l's Special Short Course No. 7, Geothermal Energy: A National Opportunity (The Federal Impact), Washington, D.C. (May 17-18, 1978).

13 Ioid.

14U.S. Fnergy Research and Development Administration, Division of Geothermal Energy, First Annual Report, Geothermal Energy Research, Development and Demonstration Program (April 1977), p. 110.

15J.5. Department of Energy, Interagency Geothermal Coordinating Council, Second Annual Report: Geothermal Energy, Research, Development \& Demonstration Program (April 1978), and Third Annual Report: Geothermal Energy, Research, Development \& Demonstration Program (March 1979). 
lower and that the results of the personal interview phase indicate that the IGCC scenario is IIkely to be optimistic.

\section{Assumptions}

With very few exceptions it appears that all increments in generating capacity will be either 50-55 MWe single turbine generator systems or dual systems counted as a 100-110 $\mathrm{WW}$ unit. This limitation on the size of a generating unit is mostly the result of constraining reservoir characteristics (e.g., well placing and limitations on distance from wellhead to the generating unit).

Since most of the manpower data available to us are predicated on the completion of a 50-55 $\mathrm{MW}$ facility, a convenient building block exists. However, there is the problem of greater or less degrees of labor intensity if one is discussing units greater than $55 \mathrm{MW}_{e}$. Intuition may lead one to conclude that a $100 \mathrm{MW}_{e}$ unit will require less manpower in all (or some) phases of development than two $50 \mathrm{MW}_{e}$ units. This has some appeal in the short run; however, several different types of generating systems w111 be required over the next ten years -- i.e., multiple flash and binary systems -- which may require more intensive manpower use than current dry steam systems. Application of new technology may allow the development of what are currently considered less productive reservoir systems, but on the other hand there is no guarantee that manpower requirements will be significantly altered with larger units. This is but one example of a number of "countervailing uncertainties" in the future development of the geothermal industry. Therefore; for this study it has been elected to assume that the manpower requirements for units significantly larger than $50 \mathrm{MN}$ are simply a linear multiple of the requirements for the $50 \mathrm{MW}_{\mathrm{e}}$ unit.

During the course of this investigation into the geothermal industry (especially pertinent is the personal interview survey) various estimates of the technical limitations and manpower requirements in various activities have been provided. In most cases respondents provided an interval estimate. Based on this format a minimum and a maximum manpower requirements schedule can be constructed. In effect this process has only decreased the uncertainty of the estimate to the extent that the range has been increased. As more information becomes available in the future, the estimated range of requirements and the margin of error should be decreased. 
The nature of the information available was quite useful in forecasting gross employment. However, an employment forecast of a more specific nature presents a number of technical problems which will be discussed later. Also, knowledge of particular occupations is supplemented somewhat from the views of employers concerning current and expected scarcities in certain occupations, as noted in Chapters 4 and 6 .

The following is the set of general assumptions underlying the forecasting model:

(1) The pace of development of electrical energy production will proceed as outlined under the previous section, Geothermal Electrical Energy Growth Scenario.

(2) The occupational structure of the Industry and of individual firms will not be radically altered from its current status by demand or supply considerations or by technological change.

(3) Technology will netther speed up nor slow down the various activities involved in bringing a power plant on line or in - operating and maintaining a power plant.

(4) Manpower requirements for plants larger (or smaller) than $50 \mathrm{MW}_{\mathrm{e}}$ are a linear multiple of the requirements derived for a $50 \mathrm{MW}$ plant, regardless of the resource characteristics.

(5) Current or proposed changes in regulatory requirements will neither increase nor decrease the pace of development.

As previously discussed, the specific assumptions follow the development of low and high estimates of requirements for varlous activities.

Low

(1) 300 person months are required to explore and assess the resource to the extent that a decision can be made as to whether or not to develop the reservoir. This excludes drilling activities but includes such efforts as aerial surveys, selsmic surveys, and resistivity surveys.
High

(1) 360 person months (same explanation and qualifications as for the low estimate). 
Low

(2) The minimum well depth requirement is 7000 feet.

(3) The maximum drilling rate is 200 feet per 24 hour day.

(4) The minimum requirement to operate and maintain a drilling rig 24 hours per day is 20 persons.

(5) 23.33 is the minimum person months required per 7000 foot well. $\left(7000^{\prime} / 200^{\prime}=35\right.$ days, and 35 days $\times 20$ persons $=700$ person days which, if divided by 30 days, $=23.33$ person months).

(6) The same requirements exist for exploratory and production wells.

(7) The minimum number of exploratory wells needed is one.

(8) The minimum number of production wells needed for a $50 \mathrm{MW}_{\mathrm{e}}$ plant is ten. Therefore, the requirement in person months would be $23.3 \times 10=233.3 .^{16}$

(9) The minimum requirement for power plant construction $\left(50 \mathrm{NW}_{e}\right)$ is 2400 person months.

(10) The manpower requirement in person months for construction of the reservoir feed system is
High

(2) The maximum well depth requirement that is economically feasible is 14,000 feet.

(3) The minimum drilling rate is 100 feet per day.

(4) The maximum requirement to operate and maintain a drilling rig 24 hours per day is 24 persons.

(5) 112 person months is the maximum required per 14,000 foot well $\left(14000^{\prime} / 100^{\prime}=140\right.$ days and 140 days $\times 24$ persons $=3360$ person days which if 'divided by 30 days $=$ 112 person months).

(6) The same requirements exist for exploratory and production wells.

(7) The maximum number of exploratory wells needed is five.

(8) The maximum number of production wells needed for a $50 \mathrm{MW}_{\mathrm{e}}$ plant is twenty-four. Therefore, the requirement in person months would be $112 \times 24=2688$.

(9) The maximum requirement for power plant construction $\left(50 \mathrm{MW}_{\mathrm{e}}\right.$ ) is 4800 person months.

(10) Same requirement as the minimum estimate (i.e., $4800 \times .25=1200$ ).

16 There has not been built into the model a method of including replacement wells. This is an extremely difficult area to quantify. However, the range of estimates should be sufficiently broad to take this factor into account. 
Low

High

25 percent of the requirement

for construction of the power

plant (i.e., $2400 \times .25=600$ ).

(11) One person (12 person months)

(11) Four persons (48 person months)

per year is required to operate per year are required to operate and maintain the reservoir feed and maintain the reservoir feed system. system.

(12) 80 person months are required

(12) 240 person months are required to construct the transmission lines for a $50 \mathrm{MW}_{e}$ plant. to construct the transmission lines for a $50 \mathrm{MWe}$ plant.

(13) 100 person months per year are required to operate and maintain a $50 \mathrm{MW}_{e}$ plant. 360 person months per year are required to operate and maintain a 50 MWe plant.

\section{The Forecast}

Total Manpower Requirements for 1980 Through 1985 Forecasted Growth (New Plants) ${ }^{17}$

Using person months as the common unit of measurement, the minimum and maximum total requirements for new plants can now be calculated for 1985 and 1990.

Estimated output in $\mathrm{MW}_{\mathrm{e}}$ for 1985 is 3090 . Using 1979 as the base year in which output is expected to be $908 \mathrm{MW}_{e}$, the difference is $2182 \mathrm{MW}$. If $50 \mathrm{MW}_{\mathrm{e}}$ is used as the building block unit of measurement, approximately 43.6 generation units will be required (either singly or combined).

The computation of the minimum manpower requirement in person months for each $50 \mathrm{MW}$ unit is as follows:

17Note that demonstration plants have been excluded from the analysis. The: manpower structure is likely to be abnormal because of their experimental nature, the legal limitation on the length of time they can operate, and, their limited size, 5-10 $\mathrm{MW}_{\mathrm{e}}$. Exclusion of this category only deletes two to three plants from analysis. 


\begin{aligned} 300.0 & (resource exploration and assessment) \\ 23.3 & (exploratory drilling) \\ 233.3 & (production drilling) \\ 2400.0 & (power plant construction) \\ 600.0 & (feed system construction) \\ 12.0 & (operation and maintenance of feed system) \\ 100.0 & (operation and maintenance of power plant) \\ +80.0 & (transmission lines construction) \\ \hline 3748.6 & (Total person months) \end{aligned}

The maximum manpower requirement in person months for each $50 \mathrm{~mW}_{e}$ unit is as follows:

\begin{aligned} 360 & (resource exploration and assessment) \\ 560 & (exploratory drilling) \\ 2688 & (production drilling) \\ 4800 & (power plant construction) \\ 1200 & (feed system construction) \\ 48 & (operation and maintenance of feed system) \\ 360 & (operation and maintenance of power plant) \\ +240 & (transmission lines construction) \\ \hline 10256 & (Total person months) \end{aligned}

Therefore, the total manpower needs in order to have $3090 \mathrm{MW}_{\mathrm{e}}$ on line in 1985 will be in the range -- 163,438.96 person months and 447,161.6 person months, calculated as follows:

$$
\begin{aligned}
3,748.6 \times 43.6 \text { (power plants) } & =163,438.96 \text { (person months) } \\
10,256.0 \times 43.6 \text { (power plants) } & =447,161.6 \text { (person months) }
\end{aligned}
$$

Dividing by 12 , the above figures are converted to a full-time equivalent (FTE) number of workers. The range in this case is $13,620-37,263$. Note that this is a considerable underestimate in the actual number of persons involved in the industry. This is especially true when considering: (1) The ease of substitution of drilling rigs between the geothermal, oil, and gas industries, (2) the uniform requirement for constructing electrical transmission lines which allows the use of the same personnel to perform this task regardless of the power source, and (3) the general ability of many firms to switch personnel from geothermal to other activities (and vice versa) as the need arises. Also, individuals responding to our mail survey indicated 
that a large number of persons are associated with the industry only on a part-time basis.

Total Manpower Requirements for 1986 to 1990 Forecasted Growth

\section{(New Plants)}

The increment in the number of $50 \mathrm{MW} e$ plants inclusive of the period from 1986 through 1990 is 124.5. Using the same computations as in the previous section, the minimum requirement is estimated to be $3748.6 \times 124.5$ $=466,700.7$ person months and the maximum requirement to be $10,256 \times 124.5$ $=1,276,872$, or 38,892 to $106,406 \mathrm{FTE}$ persons (with the same qualifications as above, that this would be a downward biased estimate).

Total Manpower Requirements for 1980 to 1990 Forecasted Growth

\section{(New Plants)}

The total number of $50 \mathrm{MW}$ plants required from 1980 through 1990 is 168.1. This implies an estimated total manpower growth requirement during this period to be:

$$
\begin{aligned}
& \text { minimum } 3,748.6 \times 168.1=630,139.6 \text { person months } \\
& \text { maximum } 10,256.0 \times 168.1=1,724,033.6 \text { person months }
\end{aligned}
$$

or 52,512 to 143,669 as a downward biased estimated range of total persons required.

\section{Net Growth in Employment}

First, very little information was obtained concerning the replacement needs of the industry, except in the drilling activity in which tumover was quite high. Therefore, replacement needs have been assumed to be zero in the forecast. Due to the nature of the relatively small size of the industry (in terms of output and employment) and the short time horizon of the forecast, such an assumption is not viewed as unreasonable.

Second, geothermal power plants are quite small (e.g., $50 \mathrm{MW}$ ) compared to a coal fired power plant complex (e.g., $\left.750 \mathrm{MW}_{e}\right)$. The accompanying manpower requirements are therefore much lower and produce socioeconomic impacts of a much smaller magnitude. The impact is of course much greater 
in areas where multiple plant developments will be concentrated, for example, in Imperial Valley. 18

Third, as are all power plants, the geothermal plants are subject to a number of regulatory screenings and controls which slow down the development process. Currently, the regulatory process, other planning requirements, and actual construction seem to require a minimum of 4-1/2 years from initial exploration to completion of the power plant. This should provide ample time for planning manpower availability and efficient utilization.

In connection with this third factor no attempt was made to time phase the manpower requirements. The reasoning was that this would only serve to unduly complicate the forecast, especially since various sources are in disagreement about the amount of power to come on line in the future and also about when and where plants will come on line.

There are two areas which can be given special consideration in determining the net employment requirements that will be generated by industry growth. The first is that one can judiclously assume that the manpower required to put a given output on line in a benchmark year will carry over into succeeding years and can therefore be subtracted from the total requirements. The second is that operations and maintenance personnel will become a fixed requirement with the physical facilities once they are established.

The first area of special consideration is perhaps the more arbitrary, but such an assumption is necessary in the effort to produce more accurate estimates. The year 1978 has been chosen as the base line year of employment. In order to meet the forecasted output for 1979 an addition of $300 \mathrm{MW}_{e}$ was made over the 1978 output which was $608 \mathrm{MW}$. In the building block estimate of $50 \mathrm{MW}$ plants this addition will therefore require the manpower capability for developing six new units. Therefore, this "existing" manpower base will be subtracted from the 1985 and 1990 total estimate of manpower requirements in order to produce the net requirements. Recall that replacement requirements are assumed to be zero throughout the eleven year period, including 1980-1990 inclusive.

I8 See, Geothermal Element: Imperial County California, National Science Foundation Grant No. ARR-75-08793. 
Given the choice of a base year to assess the existing manpower stock in order to arrive at net future requirements, Table 25 has been included so the reader can understand the discrete changes in output as forecasted for each year and how the choice of 1978 compares with other years. However, note that a few months delay (or advancement) of the power-on-line schedule for a few plants might greatly alter the percentage estimates for certain years. Also, note that different sources were used in Table 25 because not all were concermed with the same time horizon and not all began with the same base year.

TABLE 25. GROWTH IN ELECTRICAL ENERGY PRODUCTION

\begin{tabular}{lcc}
\hline Year & $\begin{array}{c}\text { Forecasted (or achieved) } \\
\text { Output in MWe }\end{array}$ & $\begin{array}{c}\text { Percentage Change } \\
\text { from Previous Year }\end{array}$ \\
\hline 1977 & 502 & - \\
1978 & $608^{\mathrm{a}}$ & 21.0 \\
1979 & $908^{\mathrm{a}}$ & 49.3 \\
1980 & $97^{\mathrm{b}}$ & 6.9 \\
1981 & $1,301^{\mathrm{a}}$ & 34.0 \\
1982 & 1,680 & 29.1 \\
1983 & 2,190 & 30.4 \\
1984 & 2,410 & 10.0 \\
1985 & 3,090 & 28.2 \\
1986 & 3,690 & 19.4 \\
1987 & 4,815 & 30.5 \\
1988 & 6,115 & 26.9 \\
1989 & 6,815 & 11.4 \\
1990 & 9,315 & 36.7 \\
\hline \hline
\end{tabular}

Estimate provided by the Geothermal Energy Institute.

${ }^{\mathrm{b}}$ Califormia Energy Commission estimate. All other estimates are from the Interagency Geothermal Coordinating Council's Third Annual Report (March 1979). 
Before subtracting the "existing" manpower base from total requirements, the second consideration, operation and maintenance personnel, must be discussed. It is reasonable to assume that each new plant and feed system w1ll require a complete operation and maintenance staff that generates an equivalent number of new hires in the industry. Therefore, since this part of the manpower stock cannot be carried over into the future plants, it must be deducted from the total stock for the base year. 19 The computations are in Table 26.

TABLE 26. EXISTING MANPOWER STOCK (IN PERSON MONTHS) FOR 1979 (i.e., capability to bring six $50 \mathrm{MW}_{\mathrm{e}}$ power plants on line).

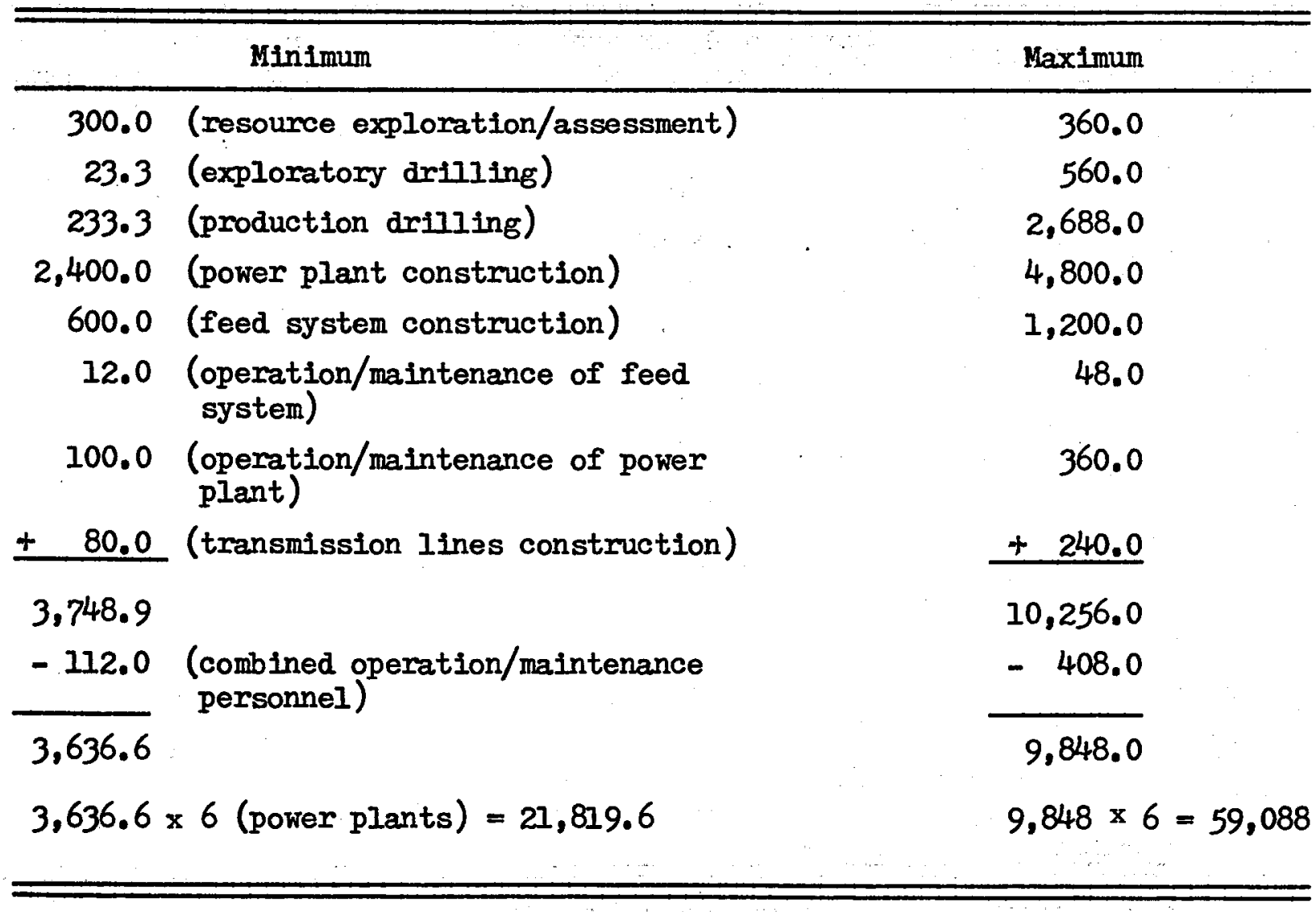

$\overline{19}$ Of course highly skilled individuals are indeed moved from one plant to another, and less skilled individuals are carefully screened for training programs that enable them to move into higher positions at new plants or existing plants. However, even if occupational growth in the industry can be managed through the internal labor market, the demand will still be forthcoming for the new hires at the bottom of the skill ladder. 
These minimum $(21,819.6)$ and maximum $(59,008)$ estimates can be deducted from the total manpower requirements for 1985 and 1990 , but a final assumption must be made. It is assumed that six power plants can be brought on line with existing capabilities by 1985 and that an additional six plants can be brought on line by 1990. Therefore, in the 1980-1990 time frame it follows that existing manpower is capable of bringing twelve plants on line. The estimates for net employment gains in the forecast are presented in Table 27.

TABLE 27. NET EMPLOYMENT GATNS IN PEPSON MONTHS

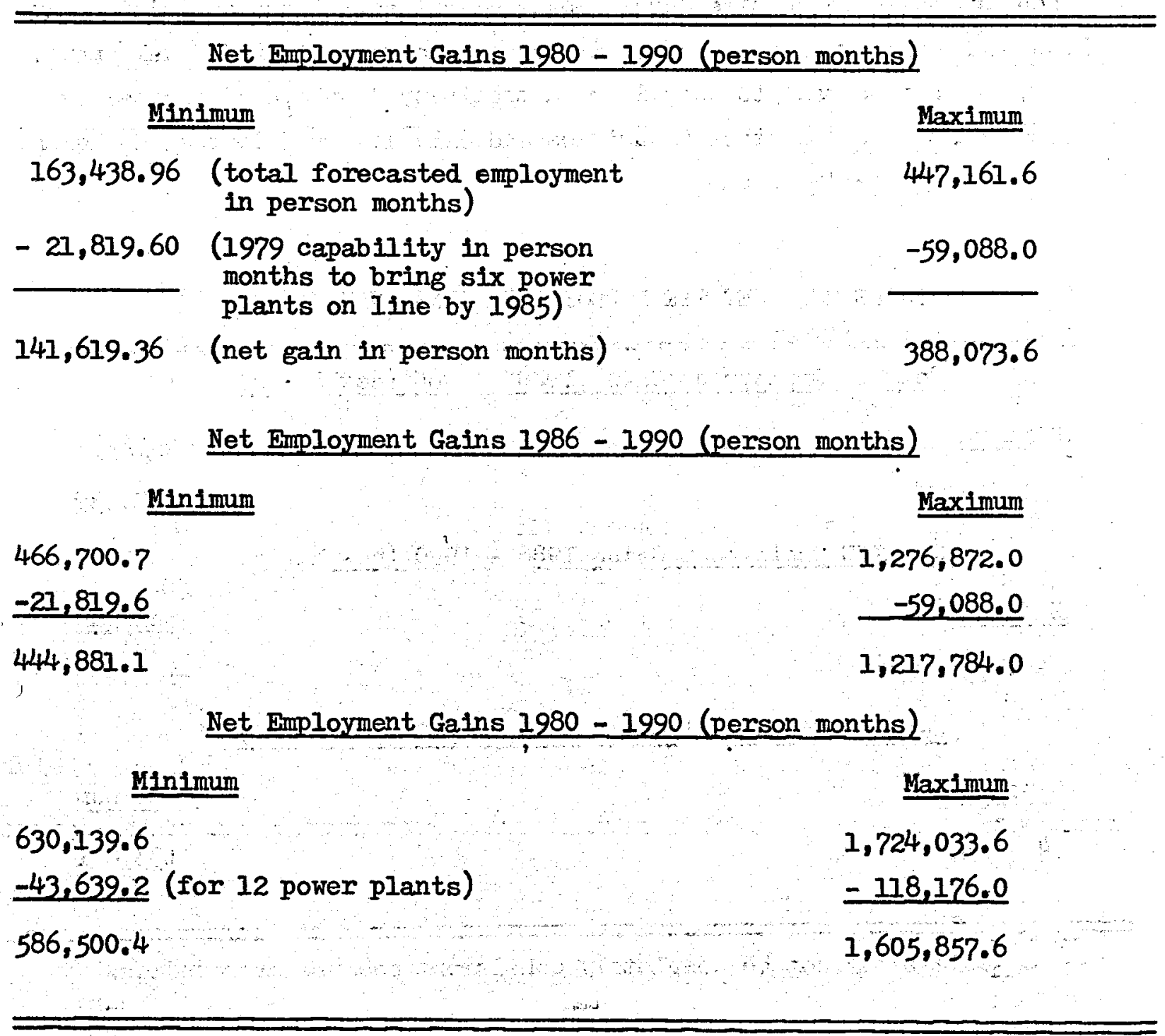


As has been previously explained, the conversion of person months to expected full-time new hires by dividing by twelve will be a considerable underestimate of the total number of people that are likely to be employed in the industry because of part-year employment and fluctuation between geothermal and nongeothermal activities. The reader is urged to keep this qualification in mind in examining Table 28.

\section{The Application of Multipliers}

The broader empirical analysis derived from the mail survey can be used to develop a general multiplier for additional employment generated in the industry based on on-site development activities. These activities may include such categories as investment, legal, and research and development. However, it is important to keep in mind that many "employees" themselves may also be attached to other industries and only involved in the geothermal industry on a part-time basis.

TABLE 28. NET FTE ENPLOYMENT GAINS (NEW HIRES)

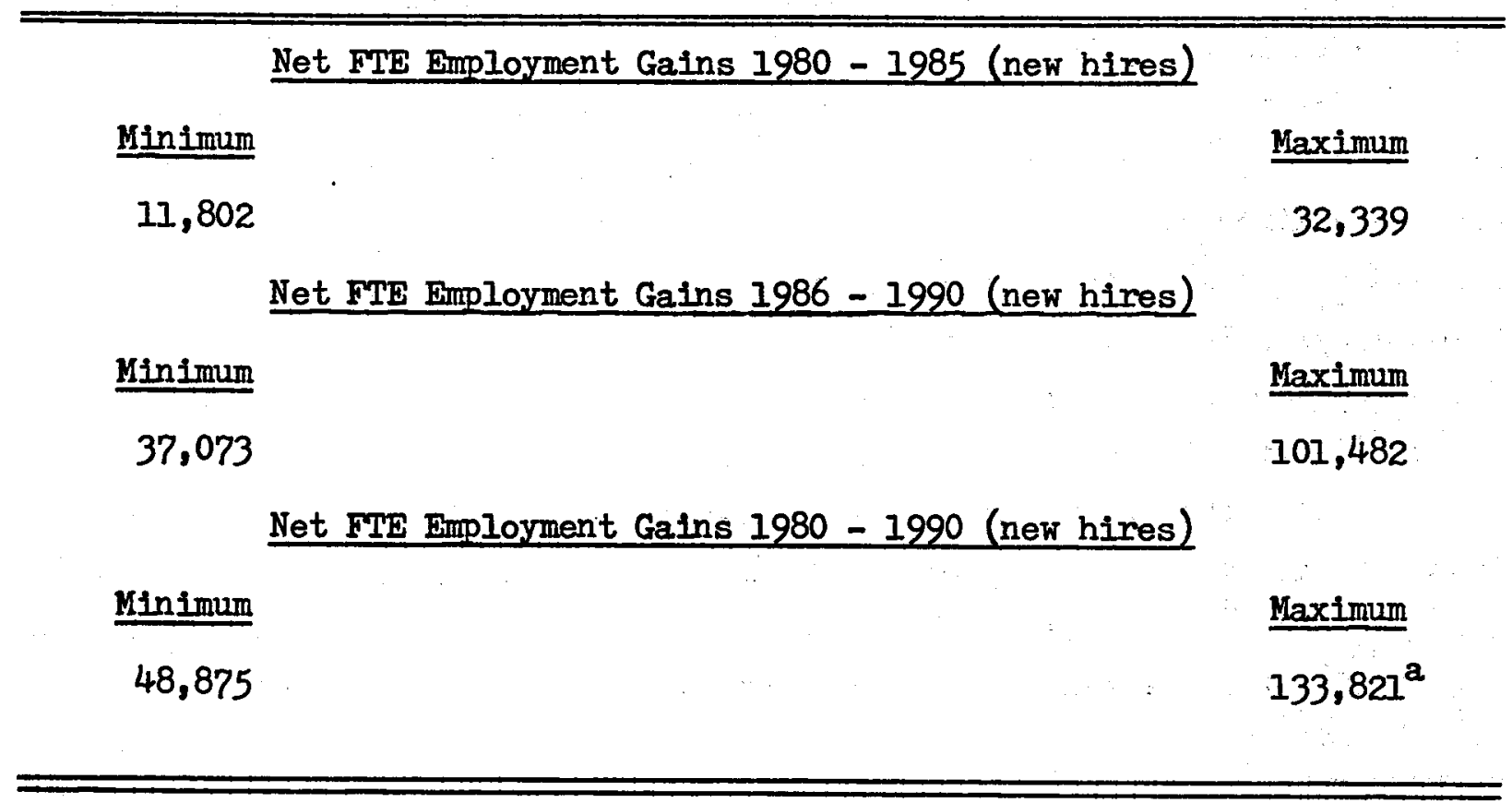

a Totals may not be completely consistent because of rounding. 
The Development of an Employment Multiplier

With the possible exception of resource exploration and assessment, the forecasting model is geared exclusively toward employment that is expected to be utilized at the development site. Therefore, for reasons of consistency, this is the portion of the matrix (see Chapter 3) which will be used as a base in developing a multiplier. A multiplier will be developed only for the private sector, but for completeness' sake, what might be the expected employment in the other three organizational types, will be given, 20

Since the forecasting model is based only on commerclal electrical energy production, other geothermal uses, such as space heating, agricultural application, and nonelectrical industrial applications, must be subtracted from the total of on-site activities. These on-site activities are denoted by the temporary activities. Therefore, 9,240 person months - 229 person months $=9,011$ person months. It should be noted that this is only what can be measurably deleted. It seems likely that some portion of the other activities (e.g., resource exploration, reservoir design, and well drilling) would be focused on direct use, but these cannot be measured. However, considering the small portion of the activities that were deleted, this should not be a serious problem.

Taking the 9,011 person months derived above, a ratio can be formed. All other person months within the matrix for the private sector which cannot be directly related to site-specific development form the numerator, or 14,538 person months, and 9,011 person months form the denominator. This gives a multiplier of $14,538 \div 9,011=1,61$ for the private sector. That is, for every person month of employment generated at the site, 1.61 person months of employment will be generated elsewhere in the industry.

since the other organizational types in the industry - state and local govermment, federal government, and educational institutions - form 30.6 percent of the total estlmated manpower, this percentage can be used as a guideline for the additlonal employment which will be generated. However,

20 Another approach could have been to develop the multiplier for all organizations taken together, but we belleve this would have introduced even more questionable assumptions about fixing the ratio of employment in other organizational types to the private sector. 
it is not recommended that it be used as a rigid multiplier. In order to. estimate the full impact of employment within the industry, the multiplier can be applied to the net employment gains which were calculated in the last section. With the same restrictions holding, the total industry employment estimates are as follows:

TABLE 29. TOTAL INDUSTFY EMPLOYMENT GATNS

Total Industry Employment Gains 1980-1985 (new hires)

$\frac{\text { Minimum }}{30,685} \quad \frac{\text { Maximum }}{84,081}$

Total Industry Employment Gains 1986-1990 (new hires)

$\frac{\text { Minimum }}{96,390} \quad \frac{\text { Maximum }}{263,853}$

Total Industry Employment Gains 1980-1990 (new hires)

$\frac{\text { Minimum }}{127,075} \quad \frac{\text { Maximum }}{347,935}$

It is important to keep in mind that the above estimates are a separate avenue of approach from the forecast by specific occupational groups in the appendix. The latter does, in part, compensate for the variety of occupations which are not directly connected with on-site developments. The multiplier approach is used here because it is quite compatible with our estimated onsite requirements to bring a power plant on line.

Secondary employment multipliers are perhaps the most uncertain. The smaller scale of field development, power plant construction, and operation and maintenance activities in the geothermal industry can be expected to produce less secondary employment than a development such as a coal-fired power plant. No secondary employment multiplier was developed for this study, but one study which evaluated the continuing development at The Geysers stated that 1.19 secondary jobs are generated for each job directly connected at the site. 21

${ }^{27}$ California Energy Resources Conservation and Development Commission, Consultant Report, p. V-C-I. 
Finally, the ability to turn a mediocre employment picture into a highly optimistic outlook by the application of a simple multiplier is recognized. Therefore, the reader is urged to study the construction of the base to which the multiplier in this study has been applied.

\section{Supply Considerations}

Established channels of manpower supply are still nonexistent in certain parts of the geothermal industry, especially where formal training programs are concerned. The geothermal industry must compete in the national market for scientific and engineering expertise. But university training for geothermal related areas is IImited to a few classes at a small number of universities and to specific training for graduate students on research projects.

The supply of drilling personnel is best understood by viewing the drilling activity as a separate industry. The problems are associated with a high turnover rate rather than initial recruitment, and the basic causal factor is the undesirable nature of the job. In the past the crucial supply consideration has been the availability of rigs rather than labor. Although this was not a main thrust of the investigation, little evidence was found to support the contention of a widespread shortage of rigs.

The supply of skilled construction personnel appears to be handled through union hiring halls, and the unskilled labor is supplied from the populace surrounding the development area. Skilled operation and maintenance personnel are basically the result of intermal promotion and training. At this point it does not appear that geothermal power plant operators have shown a proclivity to pirate skilled labor from other firms. Remote locations and slow growth have thus far precluded this type of action and provided ample time for planning mampower needs and assuring adequate suppIy. Finally, a more detalled discussion concerning supply of particular occupations can be found in the technology assessment and personal interview summary. 
Comparison of Forecasted Geothermal Bmployment with Other Energy Related Industries

In order to gain some perspective on the forecasted geothermal employment, comparisons with a few other industries are in Table 30.22 The Bureau of Labor Statistics has projected employment in a base case and in a high employment altermative case for 1985 and 1990. This facilitates easy comparison with this study's minimum and maximum estimates, and these are given as Table 30 on the following page.

Although the B.L.S. projections do not include the newer alternative energy industries, some investigators have made the following observation. "Although the subject of great interest and publicity, the 'emerging technologies - solar, geothermal, fusion, and bioconversion -- will not be large sources of new jobs over the next 8 to 10 years." 23

It is important to keep in mind that this study's forecasted employment for the geothermal industry is founded in the achievement of projected output (power-on-line) as described by the IGCC's scenario. Also, its technique of forecasting a range of employment for a given year is based on minimum and maximum labor requirements to achieve a given task or complete a particular activity (e.g., well drilling) - not on alternative output scenarios.

\section{Forecast of Employment by Occupation}

The forecast of employment growth by specific occupations stands upon much weaker logical and practical foundations than other parts of this study. The critical explicit assumption is that the occupational structure will not change during the forecasting period. Then the fixed coefficient technique is used with the additional assumption that employment has a direct (in this case, linear) relationship with output. However, the use of this

\footnotetext{
22 Information about other industries was taken from Valerie A. Personik, "Industry Output and Employments. BIS Projections to 1990;" Monthly Labor Review, 102 (April 1979), 3-14, especially pages 8-9.

23Willis J. Nordlund and John Mumford, "Estimating Employment Potential in U.s. Energy Industries," Monthly Labor Review (101) (May 1978), page 10.
} 
TABIE 30. COMPARISON OF FOREGASTED EMIPLOYMENT IN ENERGY RERATED INDUSTRTHS ${ }^{2}$

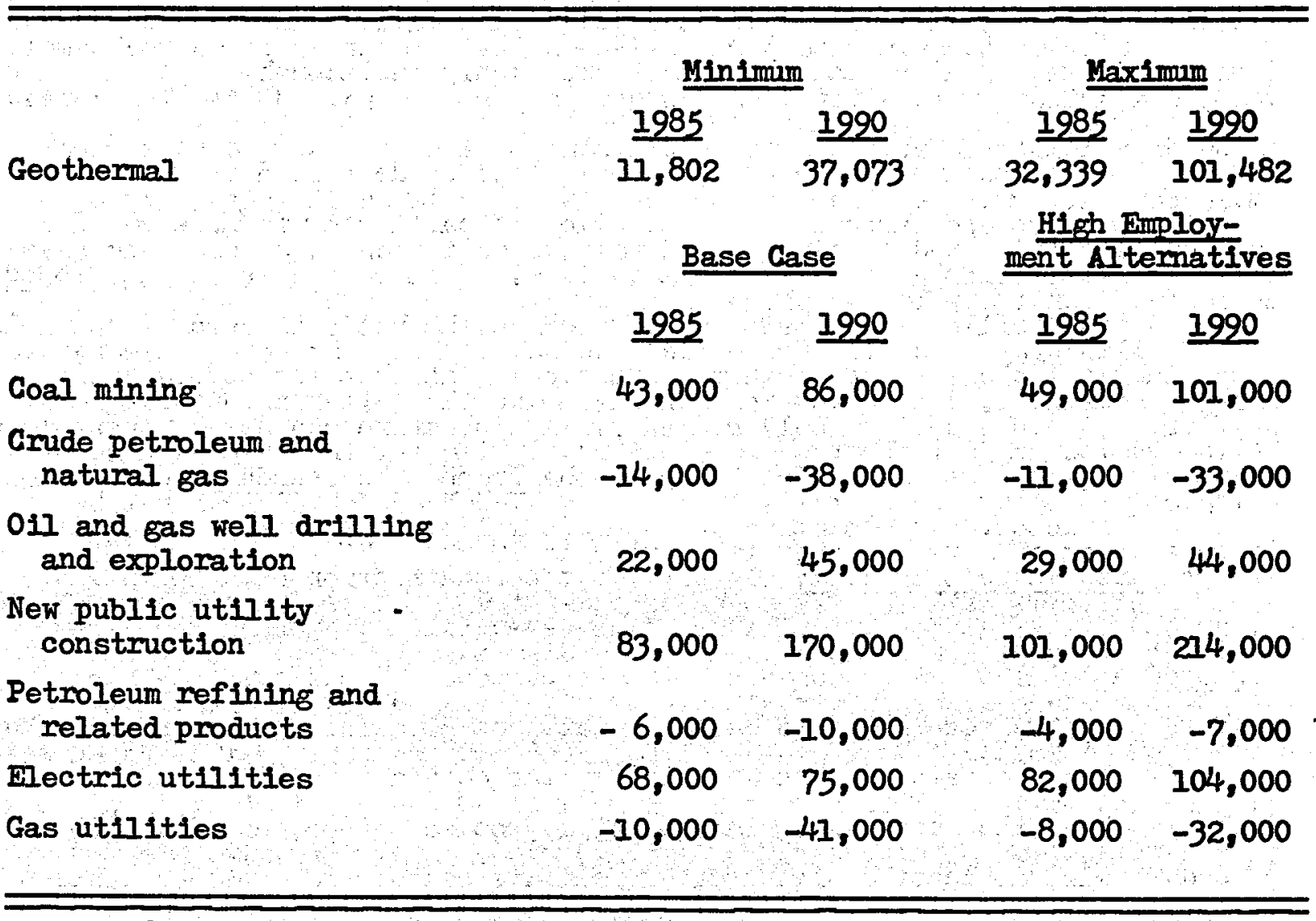

The employment figures have been computed to show the net gain in the 1980-1985 period in each industry in order that all estimates might be compatible. See footnote 22 for source of data.

technique allows two other related assumptions to creep into the model, and these must be made explicit in order to understand the weakness of this approach. The first is that a zero elasticity of substitution between different kinds of labor (as defined via occupational titles) is being assumed. Second, the function of relative wages in the labor market has been omitted. In addition to the general shortcomings outlined above there are specific problems associated with the effort. First, in order to develop a complete occupational profile of the industry two aifferent sources had to be relied upon. One is the Project Independence list of occupations, and the other is the occupational profiles developed from the personal interview phase of our study. As previously stated, the Project Independence list is 
believed to be the most comprehensive available. However, it is based on a hypothetical industry structure much different than that developed in this forecasting model. Therefore, the absolute and relative quantities of individuals required in each occupation are highly questionable for purposes of this study.

On the other hand the occupational profiles developed from the personal interviews are based on an observation of particular firms engaged in different activities at a given point in time. This contrasts to the Project Independence profiles which were constructed on the basis of need to complete a hypothetical plant in the future. One problem is that the occupational profiles in this study are only piecemeal and therefore can not by themselves be used to make forecasts. For example, the Project Independence occupational profile for resource exploration and appraisal lists that three geologists are required in this activity (leading to the construction of a $200 \mathrm{NW}_{e} \mathrm{dry}$ steam plant). In the personal interviews seven firms responded that they employed a total of 29 geologists for this purpose. Therefore, the two numbers $(3+29)$ were added to obtain a total of 32 . This is the number that appears for geologists in this activity in the occupational list and forecast in Table 31 on the next page. Though not a precise method, hopefully this procedure will at least assign greater relative weights to those occupations which have grown the most since the Project Independence estimates were made. This process was performed for each common occupation from the two sources, and when occupations were only listed from one source, the accompanying number given in that source was used. Also, efforts were made to combine some occupations under a single heading (e.g., Administrative Management/ Clerical), and to combine some different occupational titles under one term when it appeared there was no significant difference in job content ( $e_{. g}$, assistant driller and derrickman). The Dictionary of Occupational Titles (1977 Edition) was used in this effort. Tables 31 through 36 on the following pages are the results of this procedure.

The end result of the process outlined above was that each occupation has a total number of individuals which, when divided by the total number of individuals in the complete industry occupational structure, yields a proportion which can be used as a forecasting coefficient, given the above assumptions. This coefficient is then multiplied by the forecasted minimum and maximum net gain in the total employment figures for 1980-1985, 1986-1990, 
TABLE 31. RESOURCE EXXPLORATION AND ASSESSMENT

\begin{tabular}{|c|c|c|c|c|c|c|c|}
\hline \multirow{2}{*}{$\begin{array}{c}4 \\
\end{array}$} & \multirow{2}{*}{$\begin{array}{l}\text { Summed Total of Individuals } \\
\text { from Surveyed Firms and } \\
\text { Project Independence }\end{array}$} & \multirow{2}{*}{$\begin{array}{l}\text { Forecasting } \\
\text { Coefflcient } \\
\text { (percent) }\end{array}$} & \multicolumn{3}{|c|}{$\begin{array}{c}\text { Derived New Employment Estimated from } \\
1980-1985\end{array}$} & \multirow{2}{*}{\multicolumn{2}{|c|}{$\begin{array}{l}\text { Forecasted Growth } \\
\frac{1980-1990}{\operatorname{Min}}\end{array}$}} \\
\hline & & & in & $\operatorname{Max} \quad \overline{\operatorname{Mn}}$ & $\operatorname{Max}$ & & \\
\hline \multicolumn{8}{|l|}{ Solentists/Bnglineers } \\
\hline $\begin{array}{l}\text { Geologist. } \\
\text { Geophysiclst } \\
\text { Geochemlst } \\
\text { Mechanical Engineer } \\
\text { Drtliing Engineer } \\
\text { Petroleum Engineer }\end{array}$ & $\begin{array}{r}32 \\
43 \\
5 \\
2 \\
2 \\
\frac{1}{85}\end{array}$ & $\begin{array}{l}3.61 \\
4.86 \\
.56 \\
.23 \\
.23 \\
.11\end{array}$ & $\begin{array}{l}427 \\
574 \\
67 \\
27 \\
27 \\
13 \\
1135\end{array}$ & $\begin{array}{r}1338 \\
1802 \\
208 \\
85 \\
85 \\
42 \\
3560\end{array}$ & $\begin{array}{l}3664 \\
4932 \\
568 \\
233 \\
233 \\
116 \\
9746\end{array}$ & $\begin{array}{l}1764 \\
2375 \\
274 \\
112 \\
112 \\
56 \\
4693\end{array}$ & $\begin{array}{r}4831 \\
6504 \\
749 \\
308 \\
308 \\
1284 \\
12854\end{array}$ \\
\hline$\frac{\text { Administrative Manasement/ }}{\text { Clextcal }}$ & Subtotal 11 & 1.24 & 147 & 401 & 1258 & 606 & 1659 \\
\hline \multicolumn{8}{|l|}{ Spectalized Kanagement } \\
\hline $\begin{array}{l}\text { Contracting/Purchasing } \\
\text { Funanotal Analyst } \\
\text { Accounting } \\
\text { Legal } \\
\text { Land Management }\end{array}$ & subtotal $\frac{1}{\frac{1}{1}} \frac{3}{20}$ & $\begin{array}{l}.11 \\
.11 \\
.34 \\
.45 \\
1.24\end{array}$ & $\begin{array}{l}13 \\
13 \\
40 \\
53 \\
147 \\
266\end{array}$ & $\begin{array}{l}37 \\
37 \\
110 \\
146 \\
401 \\
731\end{array}$ & $\begin{array}{l}116 \\
116 \\
345 \\
457 \\
1258 \\
2292\end{array}$ & $\begin{array}{r}56 \\
56 \\
166 \\
220 \\
606 \\
1104\end{array}$ & $\begin{array}{l}154 \\
154 \\
455 \\
602 \\
1659 \\
3024\end{array}$ \\
\hline \multicolumn{8}{|l|}{ Techniclans } \\
\hline $\begin{array}{l}\text { Mngineerling Techniclan } \\
\text { Computer Analyst } \\
\text { Data Processing } \\
\text { Draftsman } \\
\text { Bxploration Technician } \\
\text { Mnvironmental Technician }\end{array}$ & $\begin{array}{r}1 \\
2 \\
1 \\
\frac{9}{6} \\
\text { subtotal } \frac{10}{29}\end{array}$ & $\begin{array}{r}.11 \\
.23 \\
.11 \\
1.02 \\
.68 \\
1.13\end{array}$ & $\begin{array}{r}13 \\
27 \\
13 \\
120 \\
80 \\
133 \\
386\end{array}$ & $\begin{array}{l}42 \\
85 \\
42 \\
378 \\
252 \\
479 \\
1218\end{array}$ & $\begin{array}{r}116 \\
233 \\
116 \\
1035 \\
690 \\
1147 \\
3337\end{array}$ & $\begin{array}{r}56 \\
112 \\
56 \\
499 \\
332 \\
552 \\
1607\end{array}$ & $\begin{array}{r}154 \\
308 \\
154 \\
1365 \\
910 \\
1512 \\
4403\end{array}$ \\
\hline \multicolumn{8}{|l|}{ Others } \\
\hline \multirow[t]{2}{*}{$\begin{array}{l}\text { Laborers } \\
\text { Truck Drlivers }\end{array}$} & $\begin{array}{l}4 \\
\frac{2}{6}\end{array}$ & .45 & $\begin{array}{r}53 \\
27 \\
80\end{array}$ & $\begin{array}{r}146 \\
\frac{74}{220}\end{array}$ & $\begin{array}{l}457 \\
233 \\
690\end{array}$ & $\begin{array}{l}220 \\
1.12 \\
332\end{array}$ & $\begin{array}{l}602 \\
\frac{308}{910}\end{array}$ \\
\hline & TOTAL 151 & & 2014 & 6327 & 17323 & 8342 & 22850 \\
\hline$\therefore$ & & & & . & & & \\
\hline
\end{tabular}


TABLE 32. DRIILIIG

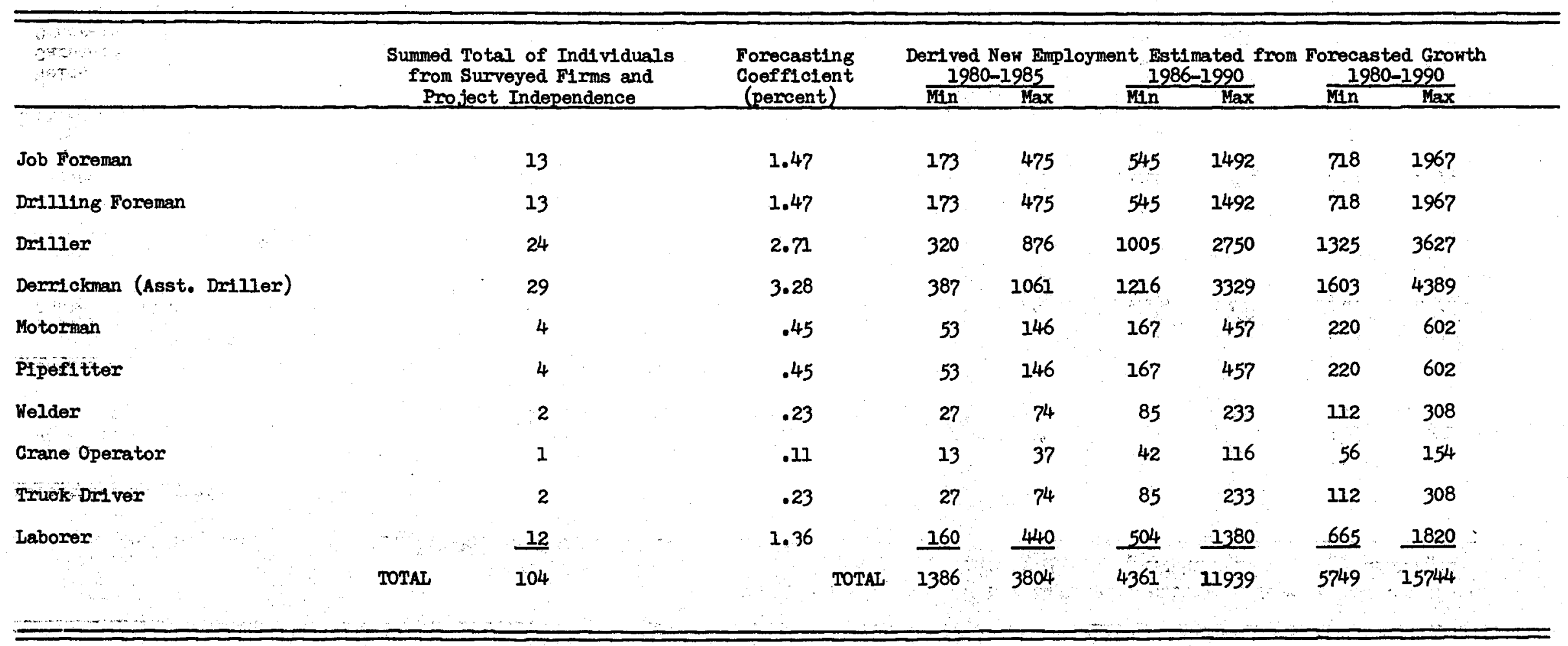


TABLE 33. RESERVOIR FHED SYSTEM (Construction)

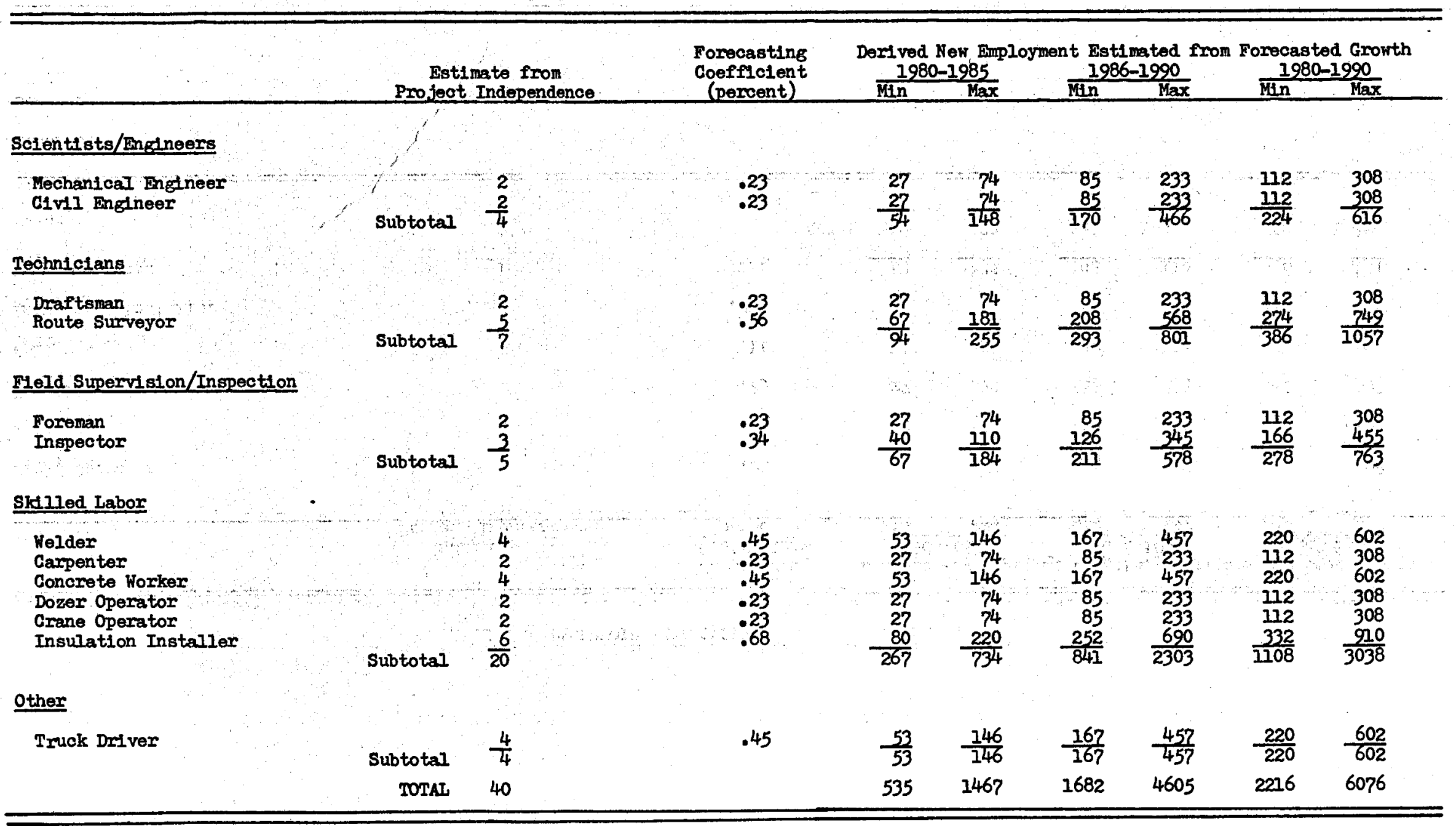


TABLE 34. RESERVOIR FEBD SYSTEMI (operation/maintenance)

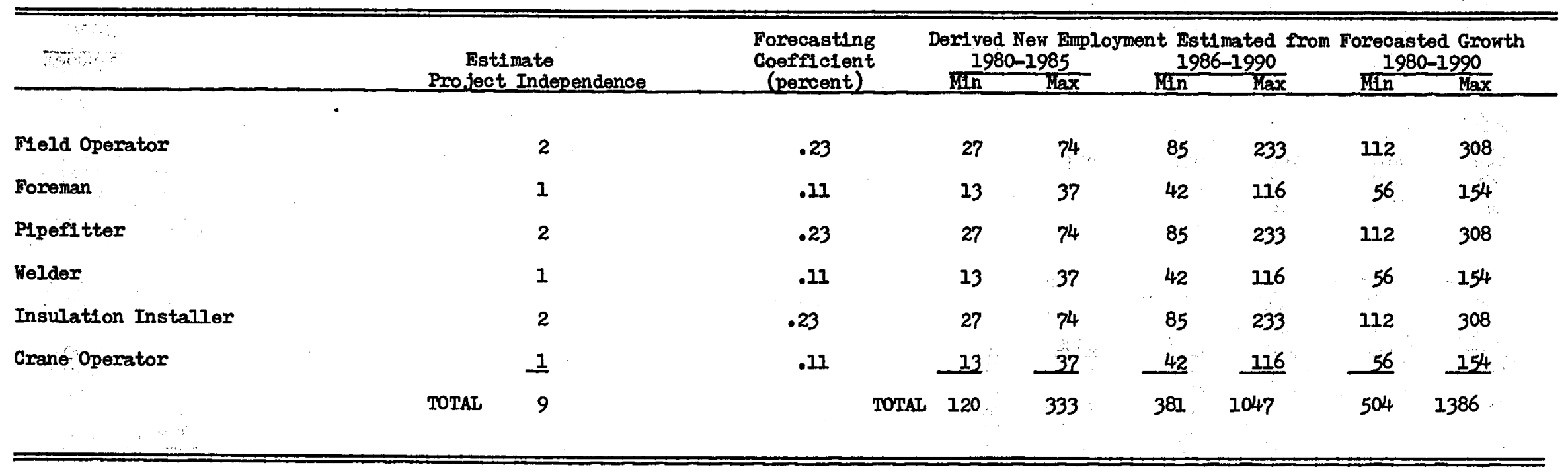


TABLE 35. CONSTRUCTION OF POWER PLANTS

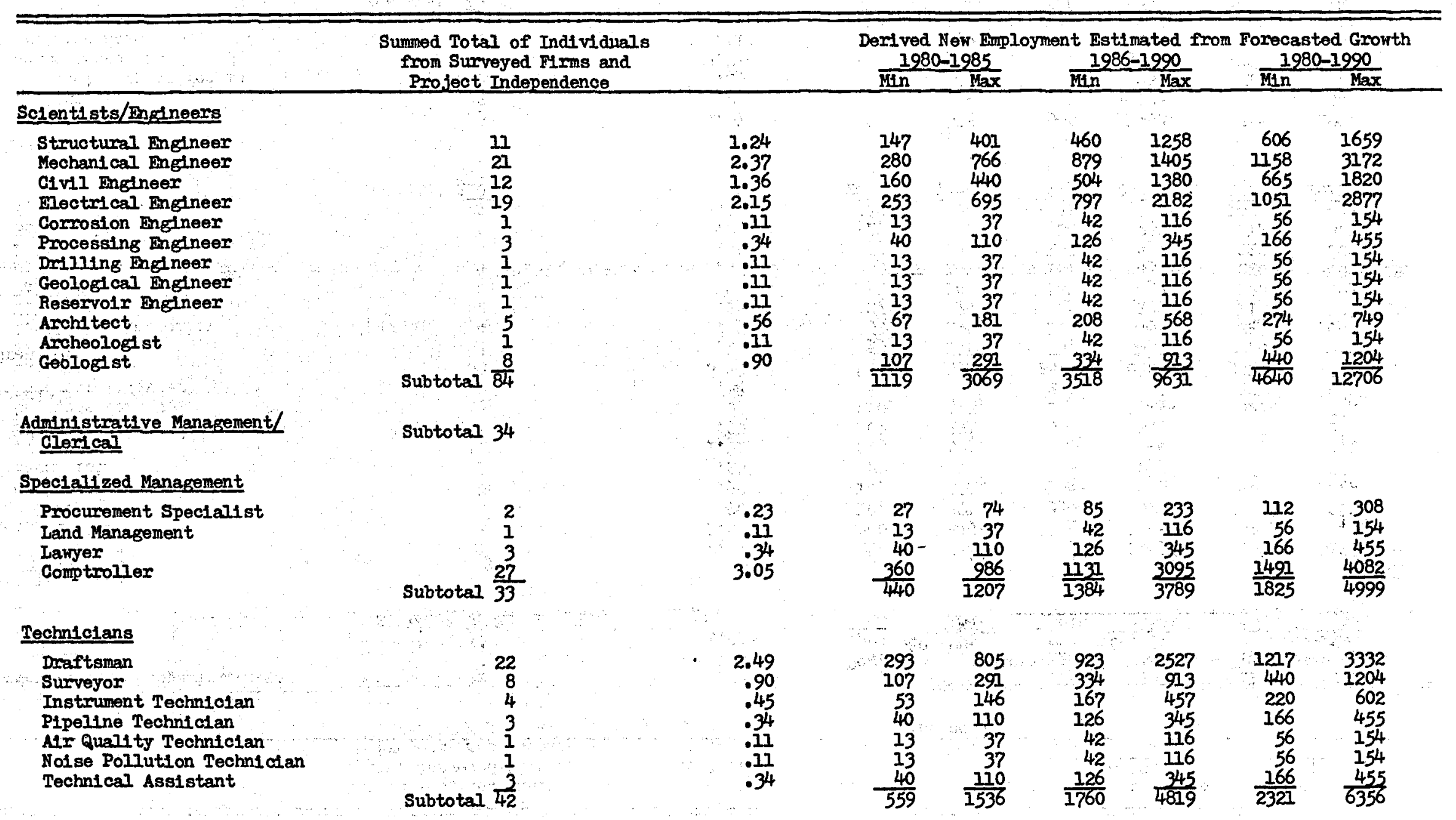


TABLE 35. CONSTRUCTION OF POWER PLANTS (cont.)

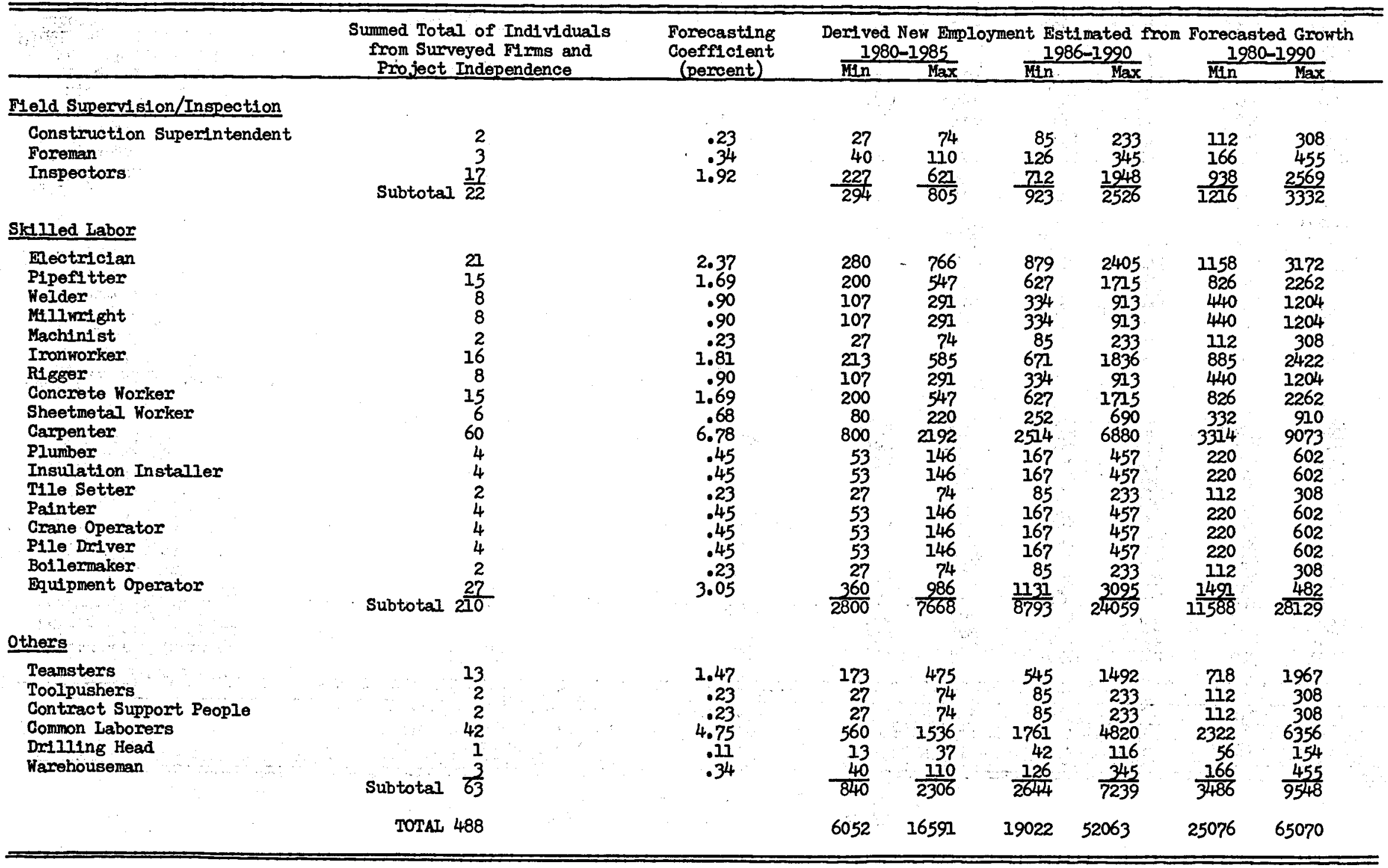


TABLE 36. OPERATION AND MAINTEENANCE OF POWER PLANT

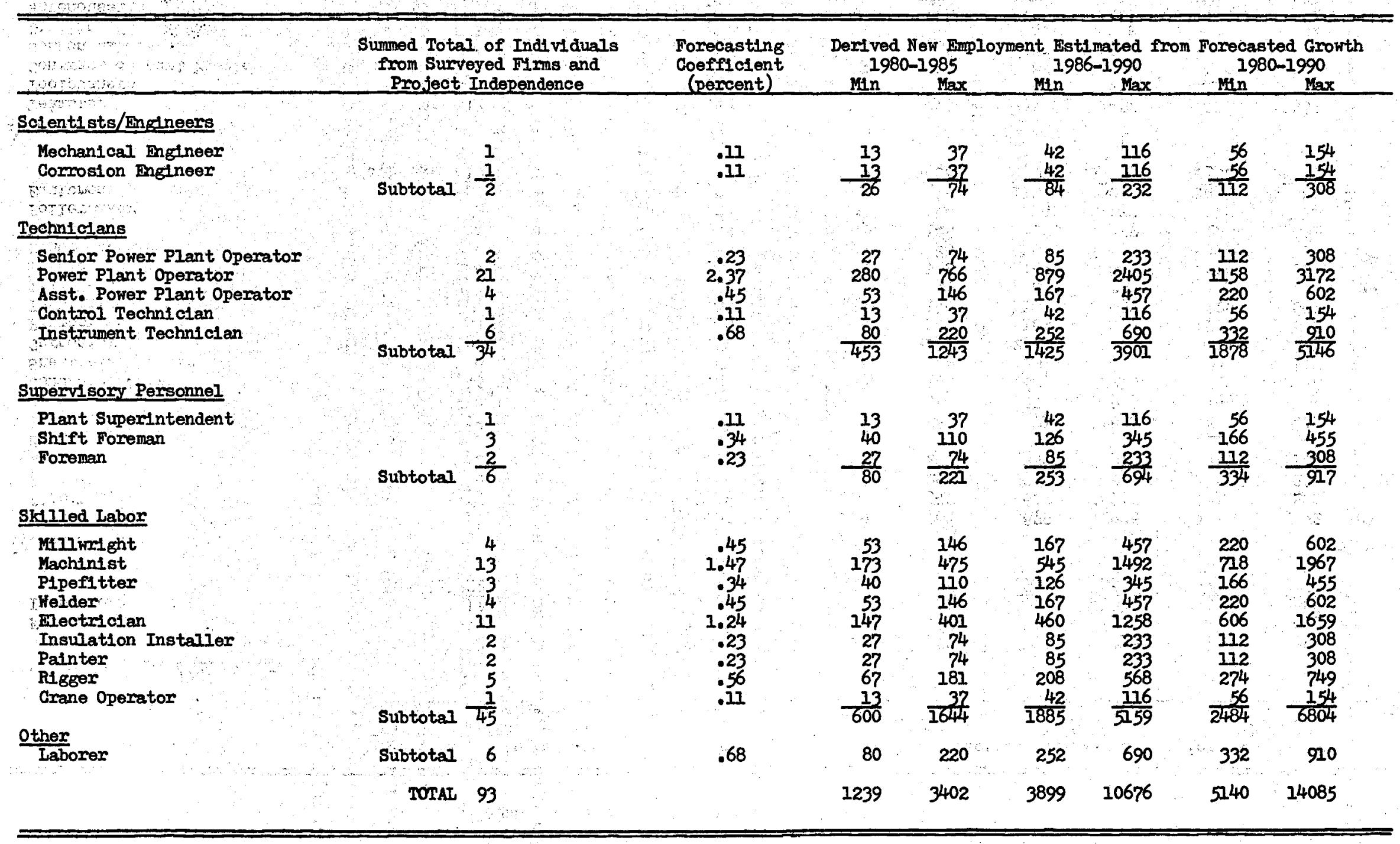


and 1980-1990. This method, therefore, yields the requirements (in the number of individuals) for each occupation for these different categories.

This forecasting approach is admittedly highly arbitrary and subject to challenges on many practical and theoretical grounds. However, there is no alternative approach available. The defense lies in whether the resultant projections are more useful than none. If so, criticisms should be directed at refining this technique or developing a better one which will yield more dependable forecasts and will more accurately reflect the unique characteristics of the geothermal resource. Finally, a liberal interpretation (based on understanding the technique used) of the actual numbers generated by the model is urged. The reader should be aware that the literature on the subject of forecasting makes it clear that even highly accurate forecasts may lead to the wrong policy cholce because of a fallure to understand the construction of the forecasting model.

Having exposed the most important pitfalls of the model and its results, some of the more positive features will be discussed. First, it is believed that a more complete and timely occupational structure of the industry than previously existed has been developed. In several areas the occupational profiles from the personal interviews revealed new occupations that were not listed in the Project Independence list -- e.g., land managers, environmental engineers and technicians, and area planners. Also, by adding the quantity of individuals in common occupations from the two sources, it is believed that the occupations which have grown the most since 1974 have received the additional relative weights in calculating their coefficients. Inspection of the results presented in Tables 31-36 reveal that many of the occupations described as bottleneck occupations in the personal interviews represent a considerable proportion of the industry, especially scientists and engineers. Based on the forecasting method, this also means their relative growth requirements will also be high, and scarcity of these types of expertise may be even more of a problem in the future. 


\section{Bibllography}

$$
\text { tast }
$$

California Bnergy Resources and Conservation Commission. Consultant Report on Environmental Analysis for Geothermal Energy Development in the Geysers Regioni Volume II, Master Environmental Assessment by Stanford Research Institute. (Project Number EGH-5554). Hay 1977.

National Science Foundation. Imperial County Galiformias Geothermal Element. (Grant Number 75-08793). 1975.

U.S. Department of Labor, Bureau of Labor Statistics. Technological Change and Its Labor Impact in Five Energy Industries (Bulletin 2005). Apri1 1979.

U.S. Federal Fnergy Administration. Froject Independence Blueprints Final Task Force Report, Geothermal Energy. November 1974.

U.S. Department of Energy, Division of Geothermal Energy. "Geothermal Development on Federal Lands - The Impediments and Potential Solutions" by Gene Beeland, et. al., (Contract Number EG-77-C01-4114). January 1978.

U.S. Department of Interior, Fish and Wildiife Service, Geothermal Project, Geothermal Handbook. (Contract Number 14-16-0008-968). June 1976. 
U 
Chapter 5

\section{TECHNOLOGY ASSESSMENT}

\section{Introduction}

The necessity for a technology assessment of the geothermal industry is founded on two basic factors. The first concerns the heterogeneous nature of the energy resource on which the industry is based. For example, the technology necessary to develop and utilize hot water, hot rock, or geopressured geothermal energy is significantly different from the technology needed for dry steam. Economic development of geothermal resources other than dry steam will require technological modifications or the introduction of new technology, assuming a favorable relationship with the prices of alternative energy resources.

The second factor creating the necessity for a technology assessment is the lack of understanding of the technical obstacles which must be overcome in order for industry growth to proceed at its anticipated rate. Technological changes that support and enhance this growth will, in some degree, alter the quantity and quality of manpower demanded by the industry vis-a-vis productivity change. In making mampower projections it is prudent to take into account the impact of technology, at least in a qualitative sense.

A by-product emerging in this part of the study that is related to current manpower assessment is the perception of whether or not scientific, engineering, and technical personnel exist in adequate quantity and quality to carry technology forward at its anticipated pace. This is not an area of investigation to be taken lightly. For example, one study has pointed out that insufficient funds or manpower is at least a "marginally significant" factor when considered as a barrier to technological innovation - ranking above insufficient funds for new facilities and unavailability of capital. 24

\footnotetext{
24 Barriers to Innovation in Industrys Opportunities for Public Policy Changes, Prepared for the National Science Foundation by Arthur D. Iittle, Inc, and Industrial Research Institutes, Inc., September 1973, p. 19. Note that this example was not a unique characteristic of any specific industry but was a widely perceived phenomenon.
} 
The importance of research and development manpower receives even greater emphasis from a different report.

It may be concluded that competent people are the major resource for innovation. A primary responsibility of management is then the selection, development, retention, and effective utilization of technical personnel, including the facilitation $8 \frac{f}{5}$ personal contacts both inside and outside the organiza-

\section{General Method of Approach}

The first step was to conduct a literature search in order to determine the extent to which the subject of technology assessment in the geothermal industry has been treated. Even though geothermal may be characterized as a relatively new or "infant" industry, there have been in recent years a number of publications dealing exclusively or in part with geothermal technology. 26 In addition the subject is continuously explored in numerous journals. 27

The literature search served dual purposes. First, it helped identify the particular technology developments necessary for projected industry growth, and second, it established the footing on which the Delphi method (explained below) was based. However, the other studies were basically geared toward assessing the impact of novel technology on industry growth and were not directly concermed with the ultimate results in terms of employment or occupational structure. Also, the validity and timing of many research forecasts changed drastically with the passage of time, influence of government policy, and the generally downward revisions of how significant a contribution geothermal energy can make on the national and local levels.

25 Successful Industrial Innovations: A Study of Factors Underlying Innovation in Selected Firms; National Sclence Foundation, 1970, p. 62.

${ }^{26}$ For example, see, Second U.N. Symposium on the Development and Use of Geothermal Resources, 3 Vols., San Francisco, 1975: A Technology Assessment of Geothermal Energy Resource Development, Prepared for the National Science Foundation by the Futures Group (April 15, 1975); Geothermal: state of the Art: Papers Presented at the Geothermal Resources Council Annual Meeting, 9-1l May 1977, San Diego, Califormia; and Paul N. Cheremísinoff and Angelo c. Morresi, Geothermal Energy Technology Assessment (Westport, Conn.: Technomic Publishing Go., Inc., 1976).

27 For example, Machine Design, Geothermal Energy Magazine, Chemical Engineering Progress, and Society of Petroleum Engineers Joumal. 
By comparison the technology assessment study undertaken by the Human Resources Institute is modest in scope and uses a more limited horizon (1985). Though the input for making manpower projections provided by this part of the study is still of a qualitative nature, it is hoped that this comparatively narrow approach is both more realistic and more precise in its results. Finally, more confidence is lent because the relatively near time horizon precludes much pure speculation about, as yet, undefined and futuristic technological products, components, or processes. However, given the Department of Energy-Division of Geothermal Energy (D.O.E. - D.G.E.) scenario for geothermal development, on which the manpower projections are dependent, there is a continuing need to evaluate the probability that these technology developments critical to the attainment of forecasted industry growth will take place. One method of doing this is to poll the industry's technical experts and solicit their judgments relating to specific technological events. The specific approach used in this study to accomplish this purpose was the Delphi method.

Delphi Method

There are a number of variants of the Delphi technique which, in some cases, are tailored for the specific research purpose. However, it is essential to adhere to certain methodological basics. What follows is, first, a general presentation of the method and, second, an explanation of how the technique was applied to technology assessment in the geothermal industry.

\section{Definition and Methodology of the Delphi Technique}

The following two excerpts are general statements of what the Delphi technique is and the procedure for its utilization.

The usual forecast attempts to predict what could be -DELPHI tries to predict what will be. DELPHI could be described as an elegant metho for developing a consensus. It is a poling techilque employed for the systematic solicitation of expert opinion. DELPHI bears deeper investigation because it is directed toward the prediction of the future as it will develop in a situation influenced by many factors beyond the control of the company or agency making the forecast. Its methodology includes the polling of experts representing the controlling factors and from the 
ensuing data develops a consensus which can be used in planning. Its advantage consists in the systematic treatment of data that includes the experts' intuitive assessment of relative imponderables. 28

Delphi is a method of systematic interrogation of experts; the interrogation is conducted anonymously by formal questionnaires and for individual members of the group of experts; a central authority evaluates the answers and makes the answers available to those interrogated in a new round of questions; after several such rounds, the result generally is that highly deviating opinions increasingly adapt themselves to one another; the questions are concerned either with an estimate of a certain year or with an estimate of a probability value for the occurrence of an event at a certain date; in the evaluation of the questions, the medians concerned and the average. quartiles of the individual answers are calculated. 29

A thorough explanation of the advantages and disadvantages of the Delphi method are extensively enumerated elsewhere and therefore do not warrant consumption of space in this text. 30 Instead, the problems of using the approach as directly related to this specific study will be pointed out in the next section. The usefulness of the technique has already been stated as being derived from its relatively simple approach to the problems of technology development.

Application of the Delphi Technique to the Geothermal Industry

The use of the Delphi technique in this study is intended: (1) to enable some perception of technological breakthroughs which are likely to

28 Marvin J. Cetron, Technological Forecasting, (New Yorks Technological Forecasting Institute, 1969), p. 145.

29K. Gewald, "The Delphi Method as an Instrument of Technological Forecasting -- Practical Experience," in Technological Forecasting in Practice, eds. Hans Blohm and Karl Steinbuch, trans. Frederick and Christine Crowley (Lexington, Mass.: Lexington Books, 1972), p. 14.

$30_{\text {See Gewald, pp. 14-16, Cetron, pp. 158-159, and Lary Evans, Production }}$ Technology Advancements: A Forecast to 1988, (Ann Arbor, Michigan: Industrial Development Division, Institute of Science and Technology, University of Michigan, 1973), pp. 37-42, and Robert U. Ayres, Technological Forecasting and Long-Range Planning, (New Yorks McGraw-Hill Book Co., 1969), pp. 148-150. 
occur by 1985 and the potential for existing or expected technology to become commercially feasible by that date; and (2) to use this information as input in forecasting manpower requirements. Because of the heavy time and resources involvement required in a Delphi study only two formal rounds of questioning were concluded. The results indicate that this was sufficient for the above mentioned purposes.

The earlier explanation of the general approach of the Delphi method might be considered idealistic because, in order to gain maximum use from the technique, one must modify it to the particular investigation being conducted. However, certain methodological procedures must be kept as pure as possible - e.8., the selection of experts and anonymity.

The basic method of selecting experts to be surveyed was to identify Individuals who had published works concerning the technology of the industry. The polling of these experts then depended on obtaining their addresses throügh such sources as the Geothermal Resources Council or Geothermal World Directory.

The above procedure was subject to two qualifications. First, in order to avoid making unreasonable requests, an effort was made to eliminate the possibility of incluaing the same persons in the Delphi study who were on the initial list for mail survey. Some exceptions were unavoidable since in many cases the Initial mall survey was addressed only to a firm, and the individual respondent was not 1dentified until the questionnaire was returned. Also, a few experts were knowingly polled in both studies because of their recognition as key figures in the industry. This dual polling factor does not appear to have produced negative responses.

The second qualification is that care was taken to ensure that the experts selected were representative of the different segments of the industry. In the selection the attempt was made to generally balance the numbers incluaed in the categories of resource exploration and appraisal, reservoir development, and energy conversion. The environmental aspects of the industry appear to have commanded relatively less attention in the literature; therefore, a smaller number of experts were identifled and surveyed in this category. 
The total number of experts surveyed in the first round was 103.31 The second-round mail survey was determined from the following tabulations.

103 total in first-round survey

$\mathbf{- 5 7}$ nonrespondents and unuseable responses

46 useable responses

- 8 declining further participation

38 potential second-round participants

- 8 further participation only by telephone or personal interview

30 total second-round mail survey

$=8$ nonrespondents to second-round survey

22 responses to second-round survey

After concluding the first-round survey, the next step was to edit the responses in order to develop a concise set of controlling technological factors to be evaluated by participants in the second round. This was a point of considerable difficulty in this study because of the technical language used by some respondents and the "non-expert" status of the controling authority. Fortunately, there is considerable literature available of an explanatory and/or definitional nature that greatly reduces this problem. Also, communications with several individuals active in the industry helped clarify many terms. However, some ambiguities did remain in the list of controlling factors, and these will be pointed out in the presentation of the statistical results. It should also be noted that the list of controlling factors used in the second round is by no means all-inclusive. This study's effort was directed only at the factors given by the participants, and no additional factors were added to the list.

31 As a first impression one might consider this number or the 30 included in the second-round mail survey to be inadequate for a valid sampling of different opinions. However, these numbers appear to be quite consistent by comparison with other Delphi studies, especially considering the more modest objectives of this study. For example, see Irene Anne Gilison, "The National Drug-Abuse Policy Delphi: Progress Report and Findings to Date," and Selwyn Enzer, "Plastics and Competing Materials by 1985, A Delphi Forecasting Study," in The Delphi Method: Techniques and Applications, eds., Harold A. Iinstone and Murray Turoff, (Reading, Mass.: Addison-Wesley Publishing Company, 1975. 
A less serious problem was created by asking the respondents to indicate their area of expertise. There were a large number of multiple responses, but there were also a significant number of responses to "other." However, these did tend to fit logically into one of the four major areas, thus indicating that some major category of experts had not been omitted from the survey. The classification of first and second-round respondents by areas of expertise is given in Tables 37 and 38.

\section{Statistical Results}

Table 39 provides the distributions of the responses of the 22 respondents to the second round of the survey. The distribution is given by percentage of responses in each category. Horizontal summations may not equal 100 percent because of nonresponse to particular factors.

The relatively large percentages expressed in the "No Judgment" category primarily result from the selection of experts in different fields of specialization. There is general consistency in that experts predominantly responded to the areas within their individually designated specialization(s) and responded less to other areas of expertise.

A few respondents pointed out the ambiguous nature of three of the factors I1sted in the survey. Two were "plugging reinjection wells" and "carbon steels:" In the case of the former the factor is the problem and thus should have been phrased within this context in order to determine if there will be a significant contribution toward the solution of the problem. For the latter factor the criticism was that it is the development of new alloys that is critical and that carbon steels are currently available. The thind factor that appeared ambiguous to respondents was the capability of drilling "wells deeper than 12-15,000 feet." Since some considered this capability to already exist, the question arose if there could continue to be a significant contribution.

A few participants observed that there was a lack of specific references to direct use technology. However, given this shortcoming and those mentioned above, the rest of the feedback was that the list of controlling factors was comprehensive. 
TABLE 37. CLASSIFTCATION OF FIRST ROUND RESPONDENTS BY AREAS OF EXXPERTISE

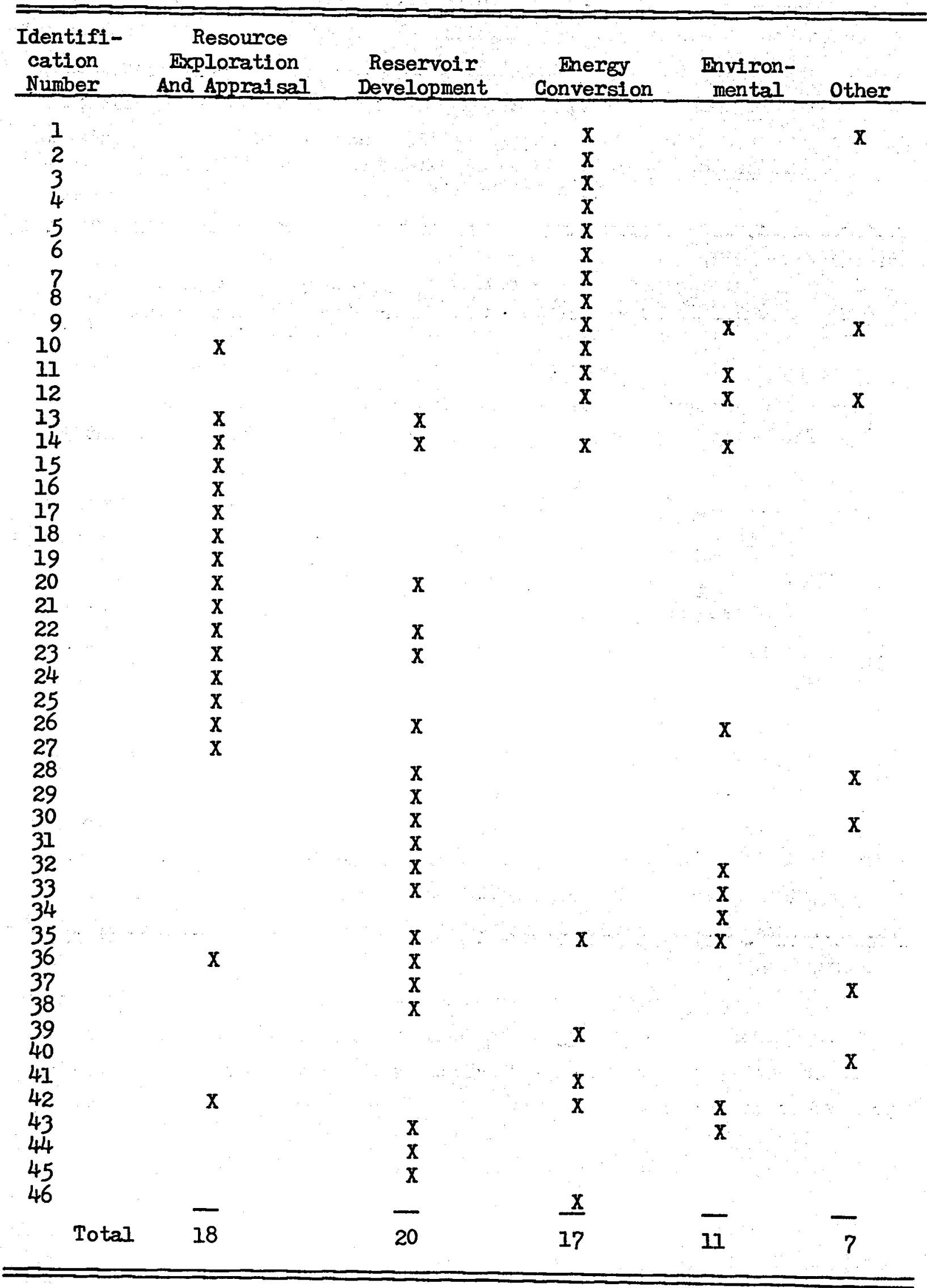


TABLE 38. CLASSIFICATION OF SECOND ROUND RESPONDENTS BY ARTAS OF EXXPERTISE

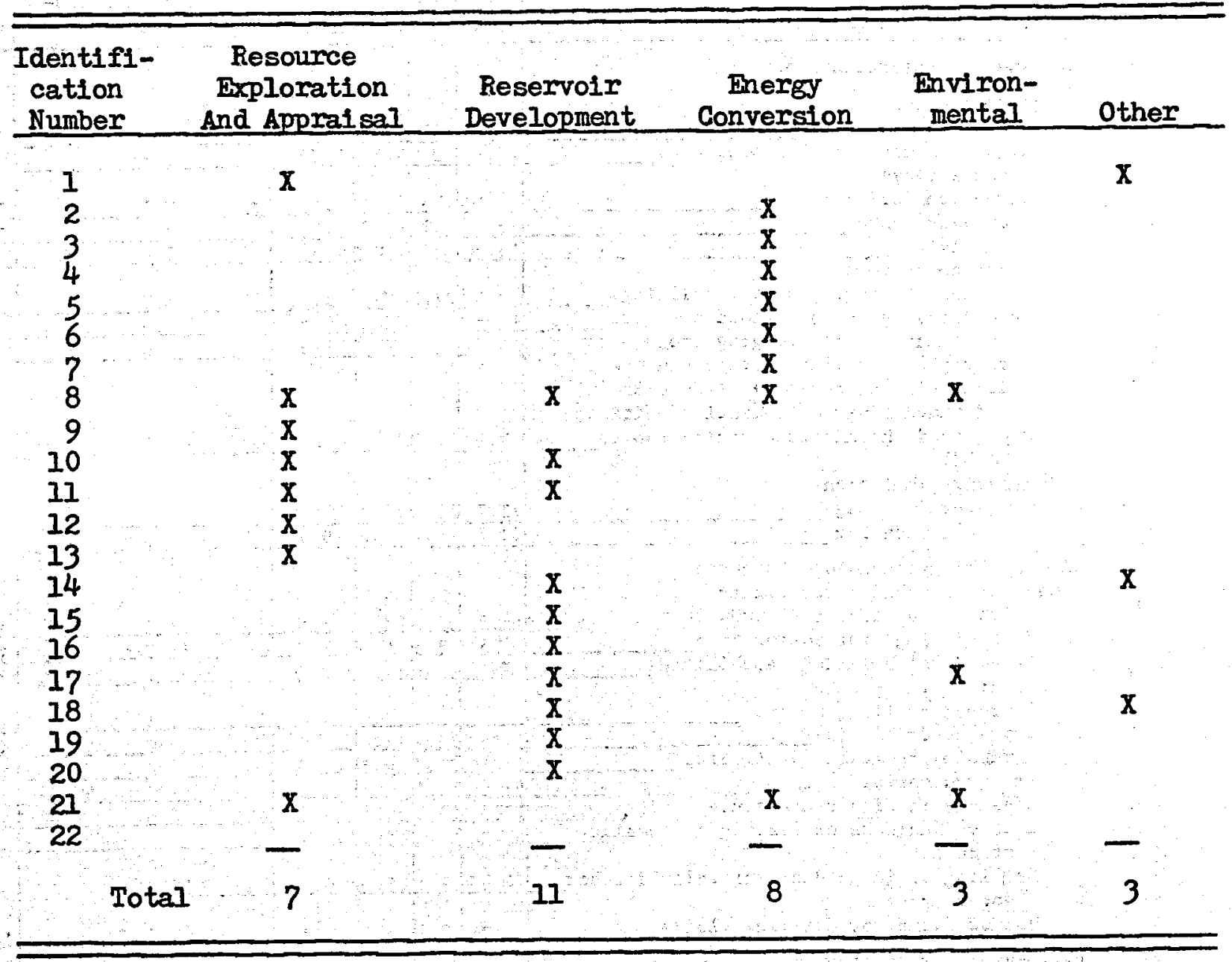


TABLE 39. GEOTHERMAL MANPOWER PROJECT/HUMAN RESOURCES INSTITUTE UNIVERSITY OF UTAH

Delphi Survey of Technology Developments in the Geothermal Industry/second Round

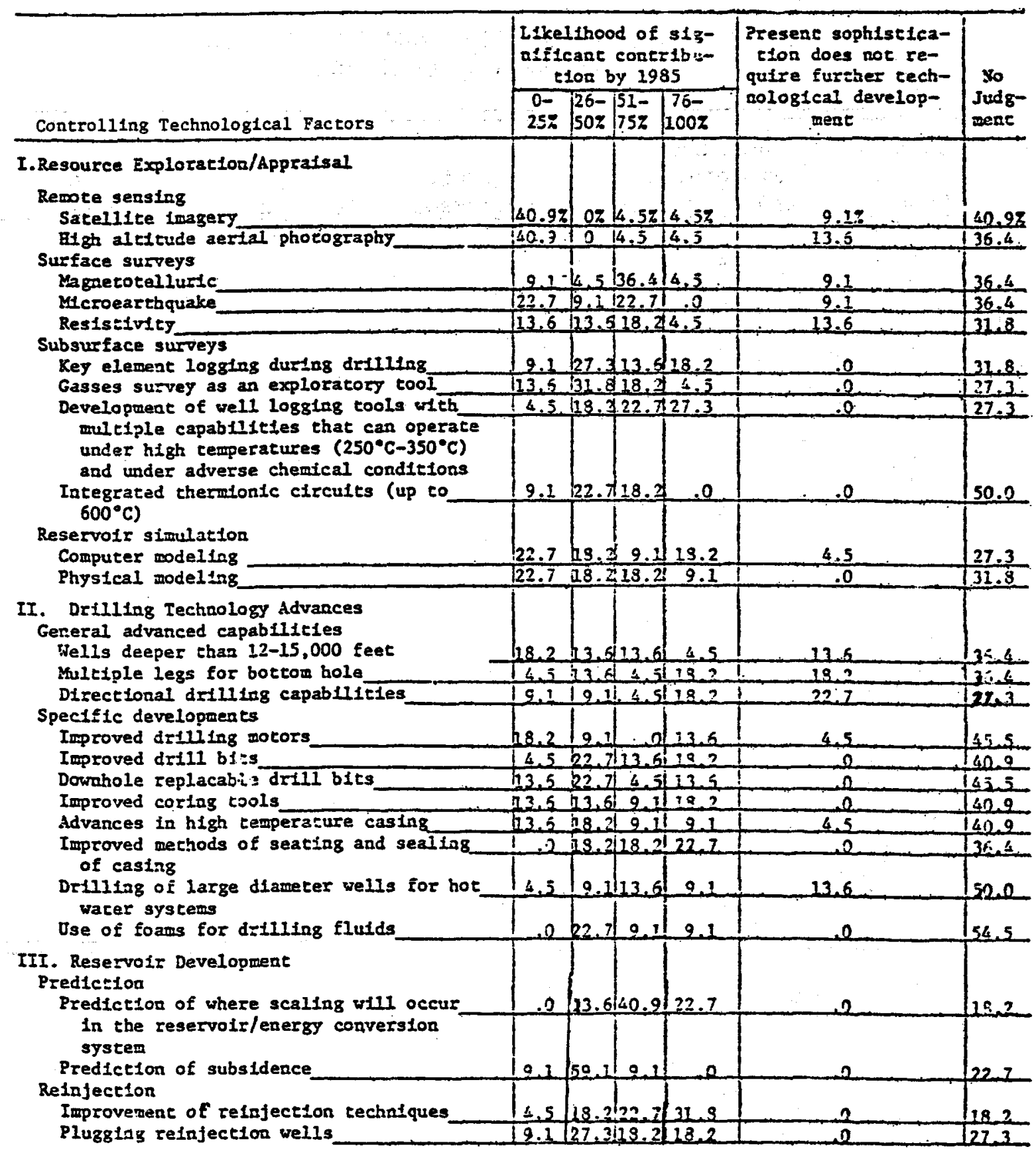


TABLE 39. (CONTINUED)

GEOTHERMAI SECOND ROUND SURVET

Page 2

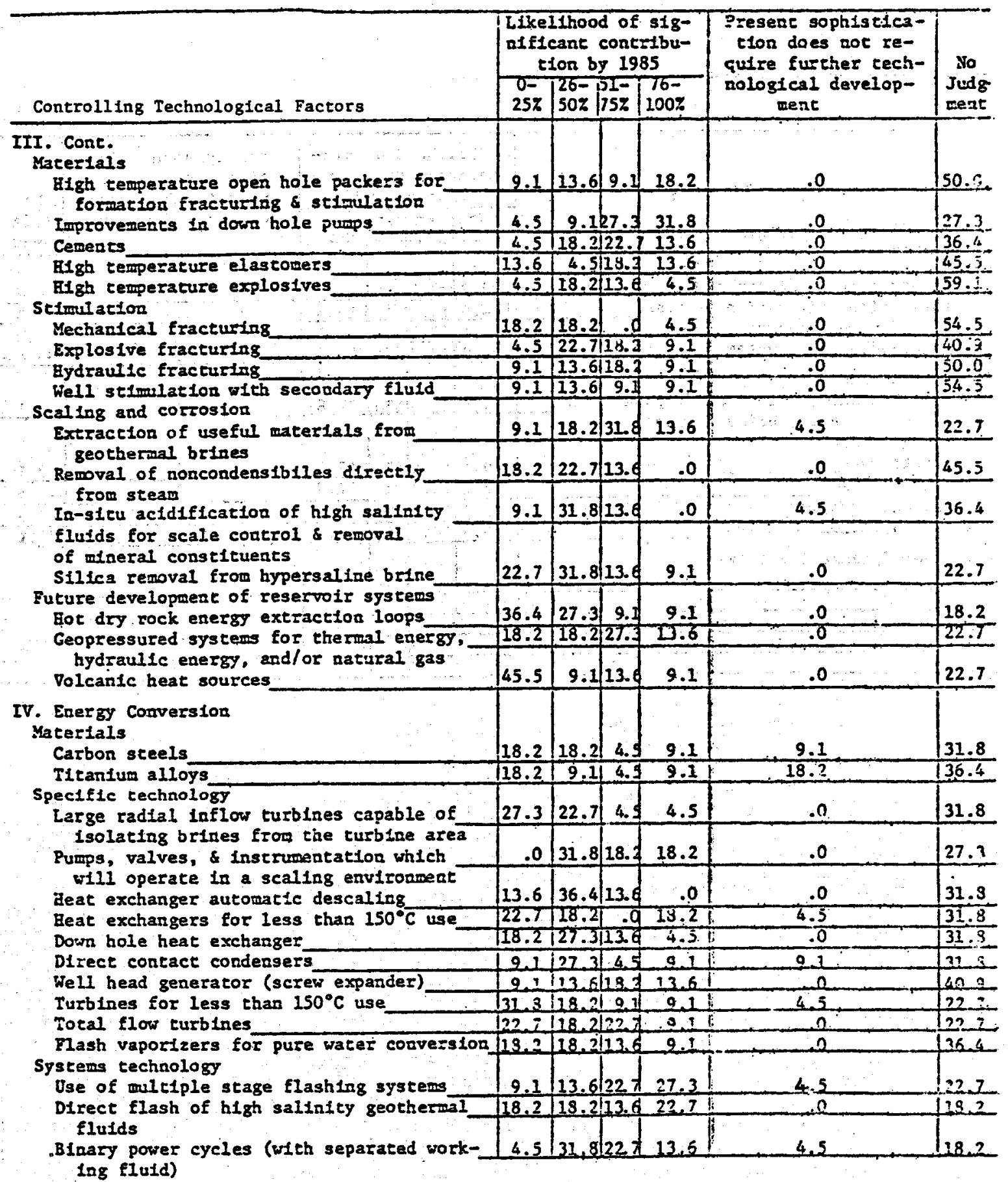


TABLE 39. (CONTINUED)

GZCTIERMAL SECOND ROUAD SURVEY

Page 3

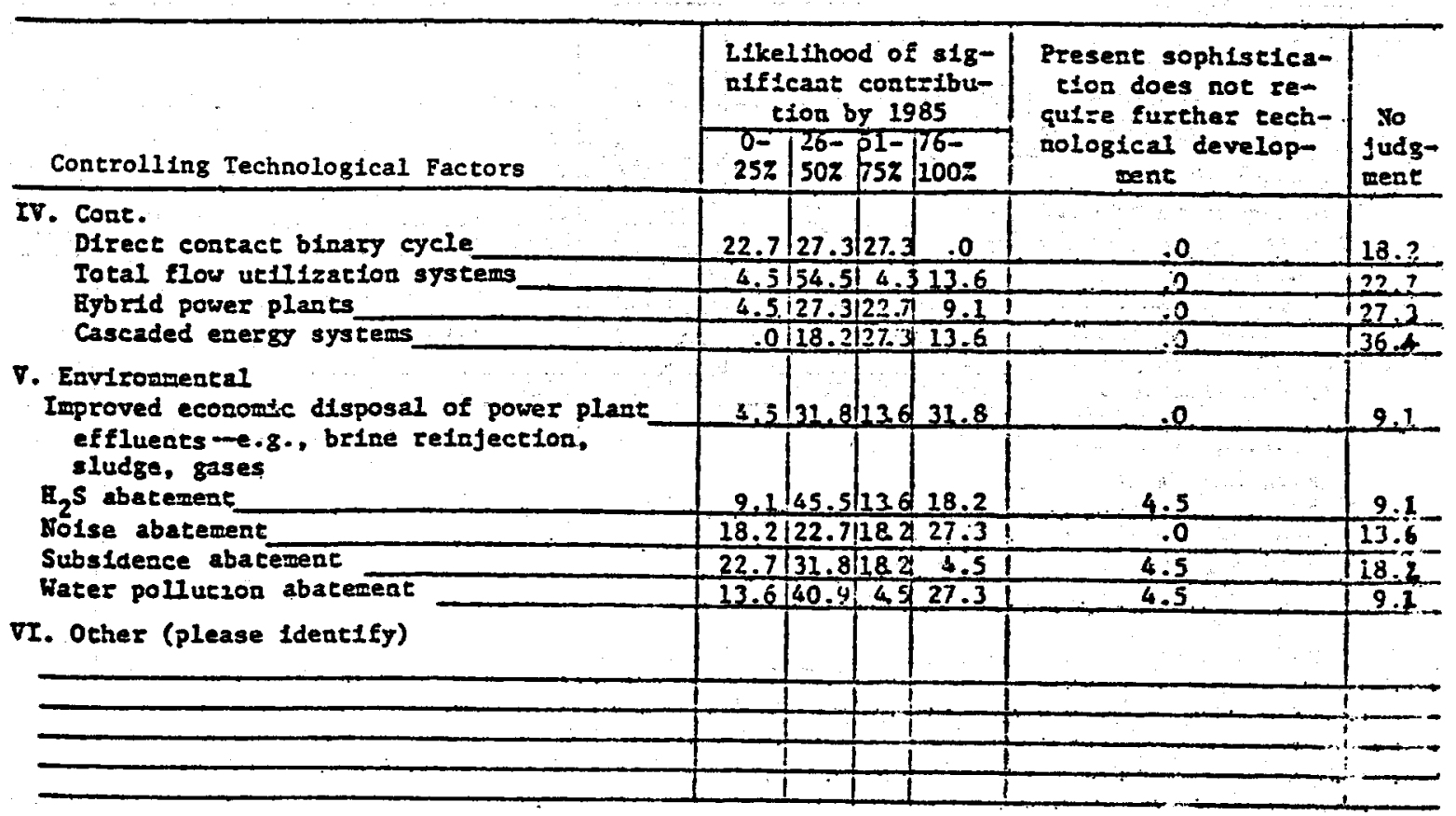


In round two the edited list of controlling factors was sent to the 30 participants who had agreed to further questioning. of these 30,22 useable responses were received. 32 The following question and explanation were given in the cover letter.

Given your area of specialization, with what probability do you expect advancing technology to enable the factors listed to make a significant contribution to the geothermal industry by $1985 ?$

Significant contribution cannot be precisely defined or quantified, but any technical development which (a) removes a serious technical impediment to the development of geothermal energy resources, (b) contributes substantially to the solution of unresolved problems in the production, development or practical use of geothermal energy, or (c) contributes directly and substantially to an increase in the production and practical application of geothermal energy can be considered to be making a significant contribution.

Referring to the results shown in Table 39 , first examine Category $I$, Resource Exploration and Appraisal. The general consensus here is that remote sensing technology - satellite imagery and high altitude aerial photography - will not make a significant contribution in appraising the inventory of geothermal resources. It appears that relatively more confidence is placed in reservoir simulation modeling; however, it should be noted that a plurality of those addressing this factor still assigned a 0-25\% probability of a significant contribution. In contrast, most of the replies to the surface and subsurface techniques were in the middle two quartiles. This appears to reinforce the view that these techniques will continue to dominate geothermal resource exploration and appraisal. The implication is that these techniques require intensive on-site use of men and equipment relative to remote sensing and reservoir simulation.

A study of the responses to Category II, Drilling Technology Advances, Indicates that the factors under general advanced capabilities will not prove a serious limitation. 33 This in part may be a reflection of technological

32 one participant responded that he did not wish to reply to the questions. Two others had moved and left no forwarding address. The remaining five failed to respond to follow-up letters and received no additional

33 communications.

This interpretation is in part based on the high proportional response in the "Present sophistication does not require further technological development" category. Also, note the earlier restriction placed on the deep well factor -- see page 99. 
developments that are transferred from the oil and gas industries into the geothermal industry. However, the factors that were listed as specific needs (as given in the round one questionnaire responses) for enhancing geothermal development were viewed with more uncertainty. Drilling technology is a cruclal area of geothermal development because of the adverse conditions (high temperatures, corrosive fluids, highly abrasive rock formations, etc.) under which drilling must take place. This problem is being approached by intensive research and development efforts. 34

Responses in Category III, Reservolr Development, point to a relatively high degree of confidence in predicting the occurrence of scaling but considerably less confidence in the prediction of subsidence. This latter result is generally consistent with the replies to the environmental (Category $V$ ) factor of "subsidence abatement." Some respondents (and others not in this study) expressed concern that the failure to find solutions to such environmental problems may pose considerable obstacles in the future.

Also in reservoir development it appears that improvements in downhole pumps are a distinct possibility. In contrast, "silica removal from hypersaline brine" was not viewed as likely to make a significant contribution. This finding may prove to be a serious limitation for development sites that are based on hot water. It is interesting to note that under the more futuristic types of reservoir systems -- hot dry rock, geopressured, and volcanic -- only geopressured received a relatively high response. As a final observation on reservoir development, note that this category was most 1ikely to have factors that were viewed as requiring further development.

Under Category IV, Energy Conversion, the subcategories of materials and specific technology yield mixed results with no apparent significant trend. Two conclusions are the large proportional responses $(27.3 \%$ and $31.8 \%$ respectively) in the $0-25 \%$ likelihood of contributions from "large radial inflow turbines" and "turbines for less than $150^{\circ} \mathrm{C}$ use." Under systems technology it seems that the leading contender is the multiple stage flashing system. However, with the exception of the "direct flash of high salinity geothermal fluids" all the other energy conversion systems listed received the largest proportion of responses in the middle two quartiles.

${ }^{34}$ At the time of this study, Sandia Laboratorles (Albuquerque, N,M.) was heavily engaged in these efforts. 
Category V, Environmental, again, yields mixed results with the largest proportion of responses being grouped in the two middle groups. To emphasize an earlier statement, many experts hold the view that environmental factors will play a larger role as the industry develops, especially with tighter regulatory controls.

\section{Conclusions}

No single technological breakthrough is Iikely to produce an unexpected boom in the geothermal industry. Advances in alternative processes and components will require complementary research and development in several related areas. A central question that has emerged in this study concerns the Iimited size of the market for geothermal technology. This Iimited market intensifies the reservations of private industry to conduct research and development because of the uncertainty of whether or not new technology can be profitably produced and marketed. On the other hand, the recognition of a currently limited market, but one with potential for considerable future growth, is the argument used to justify government involvement in research, development, and demonstration efforts.

The question of cross-fertilization of geothermal technology with the oil, gas, and mineral Industries is also central to the limited market problem. But this question remains largely unanswered. It is recommended that this subject be investigated and incorporated in a cost-benefit framework for government supported technology research.

The technology assessment study has influenced manpower assessment in several areas. First, it serves to qualify scenarios concerning industry growth and the resultant demand for manpower. In general it appears that progress will continue to be slow but steady with continued growth at The Geysers and Imperial Valley with reasonable assurance that the technical problems (e.g, scaling and corrosion) associated with the latter will be resolved. However, a general industry "boom" wiIl probably come only with the development of the geopressured resource 35 This prospect is not within

\footnotetext{
35 This possible "boom" is dependent on optimistic estimates of the thermal, kinetic, and chemical energy potential of the geopressured resource. One expert has understandably taken strong exception to a predicted industry boom, predicated on the geopressured resource especially in electrical energy production, with the view that the most impressive growth will occur in direct use applications.
} 
the time horizon of this study. Finally, one of the most significant impediments that might be expected in the future is environmental, especially the uncertainty concerning the subsidence problem.

Second, there was a small amount of direct information concerning manpower that was forthcoming from the technology investigation.

(1) Most technical experts in the geothermal industry have come from the oil and gas industries, some having received special geothermal training.

(2) Feedback from some participants indicates that the types of technical personnel currently needed are in earth sciences (e.g., geologists, geophysicists, geochemists, etc.) and engineering (e.g., reseryoir, environmental, and mechanical engineering). 36

Third, in the early stage of geothermal development much technology had to be transferred directly from other industries, particularly oil and gas. 37 This appears to be especially true in the area of resource exploration and assessment, drilling, and at least initially in pollution technology. It follows that the required manpower in these areas was also directly transferred from other industries. The second stage of development has been the alteration and adaptation of these and other techniques to the unique features of the geothermal resource. This requires specific training geared to the uniquely emerging industry. This technology study and the personal interview phase of the manpower assessment study reveal that the main method is on-thejob training, not only for scientific and technical personnel but also for skilled labor. The personal interview phase particularly points out that

${ }^{36}$ In conjunction, see Vasel w. Roberts, "New Gareer Paths in Engineering: Geothermal Energy," in Mechanical Engineering (November 1977), pp. 50-53. 37 The use of the term "stages of development" or "growth" makes no pretense to the rigor of its use in the context of economic theory. However, the idea of discussing a newly emerging industry in a developed economy in this context does not appear to be an object of economic inquiry. Still, on the surface at least, it is an intuitively appealing approach as a first step in understanding manpower growth patterns in related industries. It is suggested that this is a useful avenue of investigation in rationalizing and comparing occupational growth patterns in the various sectors of the energy industry. This would hopefully allow the recognition of common characteristics and problems which would be invaluable for policy guidance. 
spectalized degree offerings in geothermal activities do not exist in educational institutions, although some courses of an orfentation nature are available.

It appears that the industry is firmly established in this second stage, and the policy issue is whether or not it will soon advance to a third stage involving the emergence of novel technology on a wide scale and/or a significantly increased industry growth rate. The implications of such a course of events would be the greatly increased need for manpower which is highly specialized to the geothermal industry, hence the establishment of formal training programs (assuming this to be the least cost approach) capable of producing manpower in adequate quantities ensuring that bottlenecks do not emerge.

Given the results of these inquiries and given the D.O.E. - D.G.E. forecasted industry growth, it appears that only a modest effort is currently needed -- 1.e., specialized courses of training at a few existing institutions. This would establish a training base which could be gradually expanded as needed if the Industry begins to grow at a more rapid pace in the 1980 's. 
110

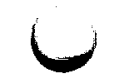

110

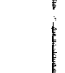




\section{Chapter 6}

\section{SUGGESTED ALTERNATIVES}

The following alternatives are based on the findings of the several parts of this study. The specific manpower problems of firms engaged in geothermal activities have led to the conclusion that a relatively modest approach will be the best policy. It is also important to keep geothermal activities in proper perspective with other energy activities. It is toward this end that some suggested alternatives have been included.

1. The most serious manpower problems that are likely to emerge in geothermal activities are in certain scientific and engineering occupations. Firms complain that they cannot effectively compete in the national market because they must absorb the costs of training and orfenting new recruits to geothermal's special characteristics, whereas educational Institutions perform that service at public expense for the o11 and gas Industries. The unlikely prospect for rapid and widespread exploitation of geothermal resources is the probable reason for this neglect.

Those organizations and governmental institutions which have the greatest interest in geothermal development should consider financtal support to expand the number of geatherma 1 courses offered at a few universities located in the western states. Demand should be sufficient to justify such modest investment, though resource-short educational institutions are unlikely to see this as a high priority. A fu11 degree offering does not appear desirable because the basics are general to many scientific and engineering areas. By being able to draw from a pool of college trained manpower that has already been oriented to geothermal activities and has received special training courses, 
geothermal employers should be in a more competitive position for recruiting relative to other energy industries.

Because of the relatively small size of the geothermal development and because of the likelihood that its size compared to other energy industries will not be dramatically altered in the next ten years, no other suggestions specific to geothermal manpower are made. Other problems that will emerge are associated with remote site developments. But these are of a short-term duration, and thus far the large firms involved in bringing power plants on line have demonstrated an ability to transfer skilled labor and other personnel as needed.

2. It is impossible to grasp the evolutionary character of a relatively new industry with a one-time study. A mail survey conducted periodically (perhaps at two or three year intervals) would help define the changing nature of the activity and the manpower structure consequently evolving. This could be done at minimal cost since the information base is now well established.

3. A more general approach to a rationalized manpower information system for the energy industries would involve development histories of the several energy industries. Coal, oil, gas, nuclear, geothermal, and solar range from the well established to the novel. Occupational structure in these industries could be examined at various stages of development in order to determine common trends. With the numerous studies that have been done over the years, sufficient documentation probably already exists for such an effort, which should be a significant'step forward in developing a conceptual framework for future manpower research. It should also be helpful in foreseeing changes which empirically oriented studies do not anticipate. Finally, decision makers could draw upon a synthesis of past studies in order to more accurately define areas of needed research and to develop a general manpower information system. 


\section{BIBLIOGRAPHY \\ (Includes References Utilized in Constructing and Evaluating the Delphi survey)}




\section{ARTICLES}

1. "Artificial Wells Boost Geothermal Potential." Engineering News-Record 198 (June 1977): 42.

2. Aronson, Robert B. "Tapping Nature's Boiler Room." Machine Design 49 (September 1977): 28-34.

3. Austin, A. I., and Lundberg, A. W. "Electric Power Generation from Geothermal Hot Water Deposits." Geothermal Energy Magazine. May 1976, 46-53.

4. Cathles, I. M. "An Analysis of the Cooling of Intrusives by GroundWater Convection which Includes Boiling." Economic Geology 72 (August 1977): 804-826.

5. Chou, C. S.; Ahluwalia, R. K.; and Woo, E. Y. K. "Regenerative Vapor Cycle with Isobutane as Working Fluid." Geothermics 3 (September 1974): 93-99.

6. Gitron, Ora R. "Institutional and Environmental Aspects of Geothermal Energy Development." Nuclear Technology 34 (July 1977): 38-42.

7. Coury, G. E. "Two-Phase Flow in Geothermal Brine Wells." Ghemical Engineering Progress 73 (July 1977): 87-88.

8. DiPippo, Ronald. "An Analysis of an Early Hybrid Fossil-Geothermal Power Plant Proposal." Geothermal Energy Magazine. March 1978: 31-36.

9. "Energy Sources: Solar and Geothermal." Power 121 (September 1977): 56-59.

10. "General Electric Awarded Contract to Test New Drilling System." Geothermal Energy Magazine. February 1977: 41.

11. "Geothermal Activity Picks Up On Federal Acreage." Petroleum Engineer 47 (July 1974): 89.

12. "Geothermal Pump To Tap Deep, Hot Brine." Machine Design 47 (May 1975): 12.

13. "Geothermal Research Encouraging." Machine Design 48 (December 1976): 6.

14. Greider, Bob. "Geothermal Energy Task Force Testimony." Geothermal Energy Magazine. March 1978: 14-25.

15. Hinrichs, Thomas C., and Falk, Harry W., Jr. "The East Mesa 'Magmamax Process' Power Generation Plant." Geothermal Energy Magazine. January $1978,44-45$. 
16. Holt, Ben. "Geopressured Resource: A Sleeping Giant." Hydrocarbon Processing 56 (July 1977): 98-100.

17. Homburg, C. D. "Geothermal Development of the Salton Sea." Chemical Engineering Progress 73 (July 1977): 89-94.

18. Hunsbedt, A.; Kruger, P.; and London, A. I. "Recovery of Energy From Fracture - stimulated Geothermal Reservoirs." JPT Journal of Petroleum Technology 29 (August 1977): 947-950.

19. "Iceland Hamesses Heat From Lava While Geothermal Projects Gather Steam." Engineering News - Record 198 (May 1977): 25.

20. Krleger, James H. "Geothermal Energy Stirs Worldwide Action." Chemical and Ingineering News 53 (June 1975): 21-23.

21. Kruger, Paul. "The NSF/RANN FY 1975 Program for Geothermal Resources Research and Technology " Geothermal Energy Magazine, April 1975: 15-20.

22. Kunze, J. F.; Whitbeck, J. F,; Miller, L. G,; and Griffith, J. L. "Making Electricity From Moderate Temperature Fluids." Geothermal Energy Magazine, October 1976: 7-16.

23. Matthews, Hugh B. "Chevron Tests Downhole Geothermal Pump." Petroleum Engineer 49 (July 1977): 82-84.

24. MaNamara, Jack. "Geothermal Reservoir Assurance - - A Problem That Must be Faced." Geothermal Energy Magazine, February 1978, 24-26.

25. Mortensen, Jeannette J. "The LASL Hot Dry Rock Geothermal Energy Development Project." LASL Mini-Review 77-8 (July 1977).

26. Mukhopadhyay, Asok K. "Economic and Engineering Implications of the Project Independence 1985 Geothermal Energy Output Goal and the Associated Sensitivity Analysis." Geothermal Energy Magazine, December 1976: 15-24.

27. Mulkin, Barb. "Steam from Hot, Dry Rockss -IASI's Geothermal Project Gets Steam." Los Alamos Scientific Laboratory Reprint from The Atom (December 1977).

28. Murphy, H. D.; Lawton, R. G.; Tester, J, W.; Potter, R. M.; Brown, D. W.; and Aamodt, R. I. "Preliminary Assessment of a Geothermal Energy Reservoir Formed by Hydraulic Fracturing." Society of Petroleum Engineers Journal 17 (August 1977) : 317-326.

29. Narath, A. "Advanced Drilling Technology." Geothermal Energy Magazine, June 19758 8-17. 
30. "New Drill Bits Hold Geothermal Promise." Geothermal Energy Magazine June 1975: 5-7.

31. "New Type Turbodrill for Geothermal Well Drilling to Get DOR Test in New Mexico." Geothermal Energy Magazine, March 1978. 13.

32. "Nippon Puts Heat on Geothermal Power." New Scientist 74 (June 1977): 717.

33. Olson, Harry J. and Dolan, William M. "Geothermal Energy - An Industry Appraisal." Mining Congress Journal 62 (March 1976): 18-21.

34. "Passive Seismic Exploration Program." Geothermal Energy Magazine. November 1975: 27.

35. Reynolds, John T. and Wagner, C. Gregory. "Application of Satellite Imagery to Geothermal Resources Exploration." Geothermal Energy Magazine, May 1975: 45-54.

36. Roberts, Vasel W. "New Career Paths in Engineering: Geothermal Energy." Mechanical Engineering 99 (November 1977): 50-53.

37. Robertson, D. E.; Crecelius, E. A.; Fruchter, J. S.; and Ludwick, J. D. "Mercury Emissions from Geothermal Power Plants." Science 196 (June 1977): 1094-1097.

38. Rowley, John C. "Geothermal Energy Development." Physics Today 30 (January 1977): 36-45.

39. "Sandia Laboratorles Develops New Iogging Tool." Geothermal Energy Magazine, April 1978: 24-25.

40. Sheinbaum, I. "Direct Contact Heat Exchangers in Geothermal Power Production." Geothermal Energy Magazine, August 1975, 13-21.

41. Sheinbaum, I. "Geothermal Well Stimulation with a Secondary Fluid." Geothermal Energy Magazine, January 1978, 33-38.

42. Sheinbaum, I. "Power Production from High Temperature Geothermal Waters." Geothermal Energy Magazine, October 1976: 17-24.

43. Stengel, R. F. "Rotary Separator/Turbine Handles Geothermal Brines." Design News 33 (May 1977): 40-41.

44. Swearingen, J. S. "Power From Hot Geothermal Brines." Chemical Engineering Progress 73 (July 1977): 83-86.

45. Takahashi, Patrick K, and Chen, Bill. "Geothermal Reservoir Ingineering." Geothermal Engineering Magazine, October 1975, 7-22. 
46. Tien-Chang, Lee. "On Shallow-Hole Temperature Measurements -- A Test Study in the Salton Sea Geothermal Field." Geophysics 42 (April 1977): $572-583$.

47. Toronyi, R. M. and All, S. M. Farouq. "Two-Phase, Two-Dimensional Simulation of a Geothermal Reservoir." Society of Petroleum Engineers Journal 17 (June 1977): 171-183.

48. "Volcanic Energy Hamessed for Hawail." 孟ectronics and Power 22 (June 1976): 22.

49. Wehlage, E. F. "Needed, Effective Heat Transfer Equipment." Mechanical Engineer 98 (August 1976): 27-33.

50. Wehlage, Edward F. "Two-Phase Energy Conversion Methods." Geothermal Energy Magazine, January 1977 : 30.

51. Wilson, J. S. "A Geothermal Energy Plant." Chemical Engineering Progress 73 (November 1977): 95-98. 
BOOKS

1. Ayres, Robert U. Technological Forecasting and Long-Range Planning. New York: McGraw-Hill Book Co., 1969.

2. Berman, Edward R, Geothermal Energy. Park Ridge, N. J. : Noyes Data Corporation, 1975.

3. Cetron, Marvin J. Technological Forecasting. New Yorki Technological Forecasting Institute, 1969.

4. Dorf, Richard C. Energy Resources \& Pollcy. Reading, Massachusetts: Addison-Wesley Publishing Company, 1978.

5. Evans, Larry. Production Technology Advancements: A Forecast to 1988. Ann Arbor, Michigan: Industrial Development Division, Institute of Science and Technology, University of Michigan, 1973.

6. Gewald, K. "The Delphi Method As An Instrument of Technological Forecasting - Practical Experience." In Technological Forecasting in Practice, 13-18. Edited by Hans Blohm and Karl Steinbuck, trans. Frederick and Christine Crowley. Lexington, Massachusetts: Lexington Books, 1972.

7. Herman, Stewart W., and Malefatto, Alfred J. Energy Futuress Industry and New Technology. Cambridge, Massachusetts: Ballinger Publishing Company, 1977.

8. Linstone, Harold A. and Turoff, Murray, editors. The Delphi Method: Techniques and Applications. Reading, Massachusettsi AddisonWesley Publishing Company, 1975.

9. McMullan, J. T.; Morgan, R.; and Murray, R. B. Energy Resources and Supply. Chichester: John Wiley \& Sons, $197 \overline{6 .}$

10. Wahl, Edward F. Geothermal Energy Utilization. New York: John Wiley \& Sons, 1977. 
DOCUNERTS, REPORTS, AND PROCEEDINGS

1. Austin, Arthur I. ; Lundberg, Anders W, , Owen, Larry B.; and Tardiff, George F. The LLL Geothermal Energy Program Status Report, January 1976 - January 1977.

2. Consultant Report on Environmental Analysis for Geothermal Energy Development in the Geysers Region - Volume II Master Environmental Assessment. Prepared by Stanford Research Institute for the California Resources Conservation and Development Commission (Project Number BGH-554), Nay 1977.

3. Federal Energy Administration. Project Independence: Geothermal Energy. Washington, D.C. U U,S. Government Printing Office; 1974.

4. Geothermal Resources Council. A Conference on the Commercialization of Geothermal Resources. San Diego, Califormia: n.p., 1978.

5. Geothermal Resources Council. Direct Utilization of Geothermal Energy. San Diego, Callforntal n.p., 1978.

6. Geothermal Resources Counc11. Geothermal Energy, A Novelty Becomes A Resource. Hilo, Hawail, n.p., 1978.

7. Geothermal Resources Council. Geothermal, State of the Art. San Diego, Californiat n.p., 1977.

8. Jet Propulsion Laboratory. Program Definition for the Development of Geothermal Energy, Volume Is Background and Program Definition Summary: Volume II: Program Definition Development Rationale and Subprogram Descriptions, Volume III: Appendixes. Contract Number NAS 7-100) 1975 .

9. Los Alamos Scientific Laboratory. Hot Dry Rock Geothermal Bnergy Development Project: Annual Report, Flscal Year 1977 (LA-7109-PR).

10. Sandia Laboratories. GeoEnergy Technology. Albuquerque, New Mexico: n.p. (no date).

11. Second U.N. Symposium on the Development and Use of Geothermal Resources, 3 Volumes. San Francisco. 1975.

12. State of Califormia, The Resources Agency, Department of Water Resources. Water and Power from Geothermal Resources in Califormia. 1974.

13. The Futures Group. A Technology Assessment of Geothermal Energy Resource Development. WashIngton, D.C.: U.S. Government Printing Office (Contract Number L-836), 1975. 
14. Trehan, Ranir K.; Leigh, John G.; Williams, Fellcia; and Pond, Susan. Analysis of Geothermal Energy Development Scenarios. n.p. (Contract Number E(49-18)-2268) 1976.

15. U.S. Department of Energy. Environmental Development Plan. Springfield, VA. 1 National Technical Information Services, 1978.

16. U.S. Department of Energy, Division of Geothermal Energy. Geopressured Geothermal Fairway Evaluation and Test-Well Site Location, Frio Formation, Texas Gulf Coast, by D. G. Bebout, R. G. Loucks, and A. R. Gregory. Springfield, VA: National Technical Information Service (Contract Number AT-E(40-1)-4891) 1978.

17. U.S. Department of Energy, Interagency Geothermal Coordinating Council. Geothermal Energy, Research, Development and Demonstration Program. Washington, D.C.: Division of Geothermal Energy, 1978. (D.O.E.) ETT-0039/1, IGCL-3)

18. U.S. Department of Energy, Division of Geothermal Energy. Geothermal Loop Experimental Facility, by H. K. Bishop, C. S. Cooney, W. H. . Hanenburg, N. C. Hodgdon, W. O. Jacobson, K. K. Li, and C. R. Swanson. Springfield, VA, National Technical Information Service (Contract Number EY-76-L-03-1137), 1978.

19. U.S. Department of Energy, Division of Geothermal Energy. Geothermal Resources, Vicksburg Formation, Texas Gulf Coast, by R. G. Ioucks. Springfield, VA: National Technical Information Service (Contract Number AT-E(40-1)-4891), 1978.

20. U.S. Department of Energy, Division of Geothermal Energy. Geothermal Resources, WIIcox Group, Texas Gulf Coast, by D. F. Bebout, V. J. Gavenda, and A. R. Gregory. Springfield, VA: National Technical Information Service (Contract Number AT-E(40-1)4891), 1978.

21. U.S. Department of Energy, Division of Geothermal Energy. Prospects for Improvement in Geothermal Well Technology. Springfield, VA: National Technical Information Service (Contract Number BG-77-C$01-4014), 1978$.

22. U.S. Department of Inergy, Division of Geothermal Energy. The Results of the Initial Feasibility Program on Cavitation Descaling Techniques for Pipes and Tubes Used in Geothermal Energy Plants. Springfield, VA: National Technical Information Service (Contract Number $\mathrm{E}(49-18) 2289), 1978$.

23. U.S. Energy Research and Development Administration, Division of Geothermal Energy. Geothermal Energy Research, Development \& Demonstration ProBram (ERDA 77-9), 1977.

24. U. S. Environmental Protection Agency. Pollution Control Guidance for Geothermal Energy Development by Robert P. Hartley. Springfield, VA: National Technical Information Service (EPA 600/7-78-101), 1978. 
25. U.S. Environmental Protection Agency. Survey of Environmental Regulations Applying to Geothermal Exploration, Development, and Use, by Mrs. Gene V. Beeland. Springfleld, VAs National Technical Information Service (Contract Number 68-03-2371), 1978. 
122

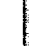


Appendix A

DISCUSSION AND DEFINITIONS

OF THE EMPLOYMENT MATRIX

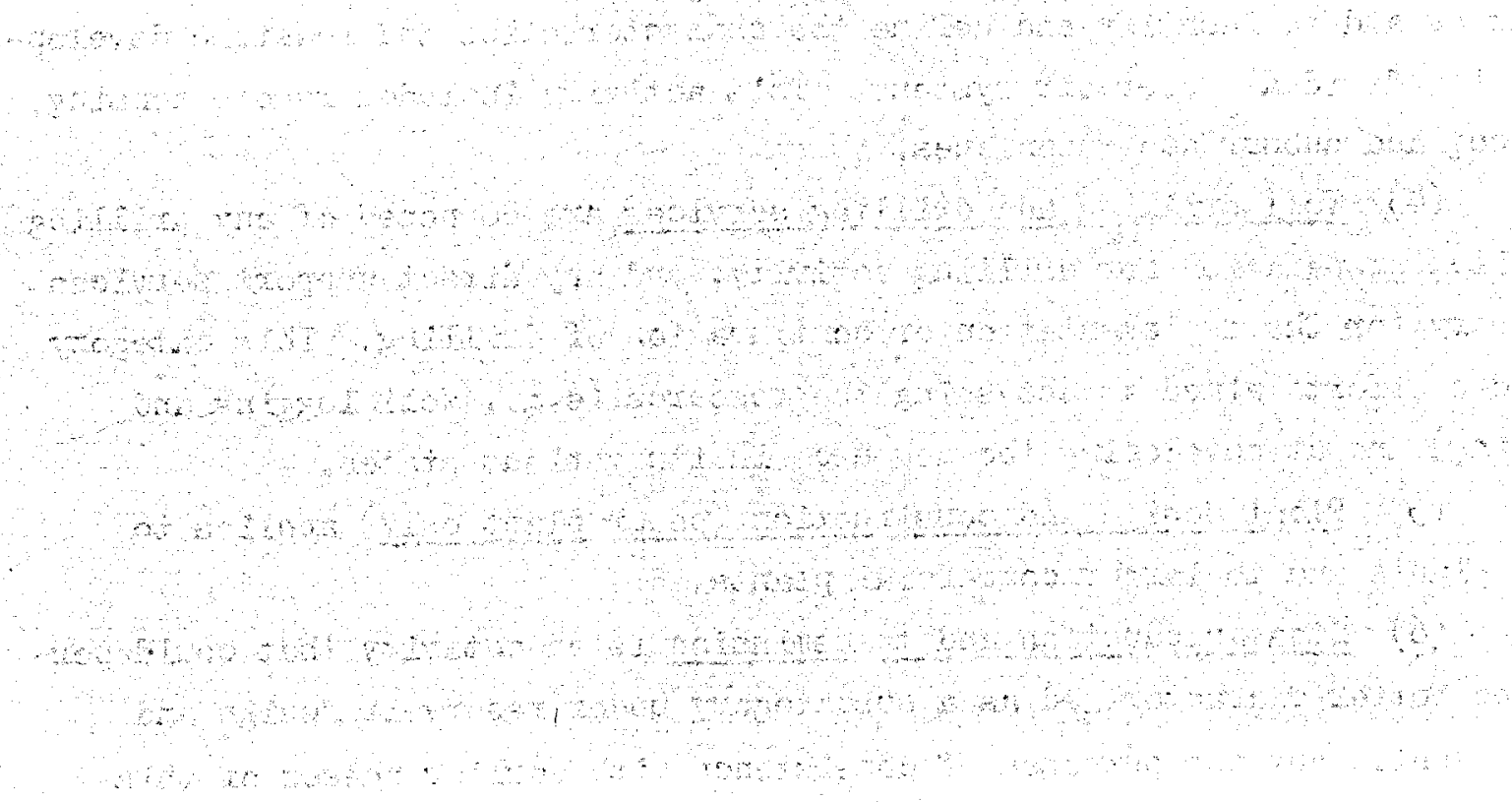




\section{Definition of Activities}

The original attempt was to break down the distribution of person months by activity only. However, replies to the solicitation of activity by area of specialization greatly complicated this effort to the point that precise analysis by activity was impossible in many cases. Even in the revised list of activities (see Figure A-1, page 125) there remain some conceptual problems of overlapping involvement (e.g., whether drilling should be a separate category). Still, the revised list of activities, coupled with particular phases of involvement, lends greater precision to the determination of where human resources are allocated. The specific activities used in classifying the initial responses are generally meant to be interpreted as the necessary stages of development at the resource site to bring about the utilization of the resource for electric generating and direct use applications which are socially, economically, and environmentally sound.

(1) Disassociated. This category was used in the reclassification of responses because many memorandum replies to the "other" category could not be associated with a particular activity. Therefore, a disassociated designation means that person months can be at least identified by either an activity or a phase.

(2) Resource exploration/assessment (exclusive of drilling) includes any site-specific, regional, or national effort to inventory geothermal resources and to identify and define the characteristics and feasible development of individual reservoir systems. This activity includes remote sensing, surface, and subsurface techniques.

(4) Well drilling and drilling services are composed of any drilling activity, preparation for drilling activity, and any direct support services necessary for the implementation or continuation of drilling. This category includes efforts aimed at assessing the resource (e.g., well logging and sampling) and at developing the resource in its various states.

(5) Plant design and construction (power plant only) applies to pilot plants and to larger commercial plants.

(6) Steam production and transmission is an activity that could perhaps be better characterized as a subcategory under reservoir design and development. But for purposes of consistency with earlier phases of this study, it was necessary to maintain the general taxonomy. However, listing 


\section{FIGURE A-I}

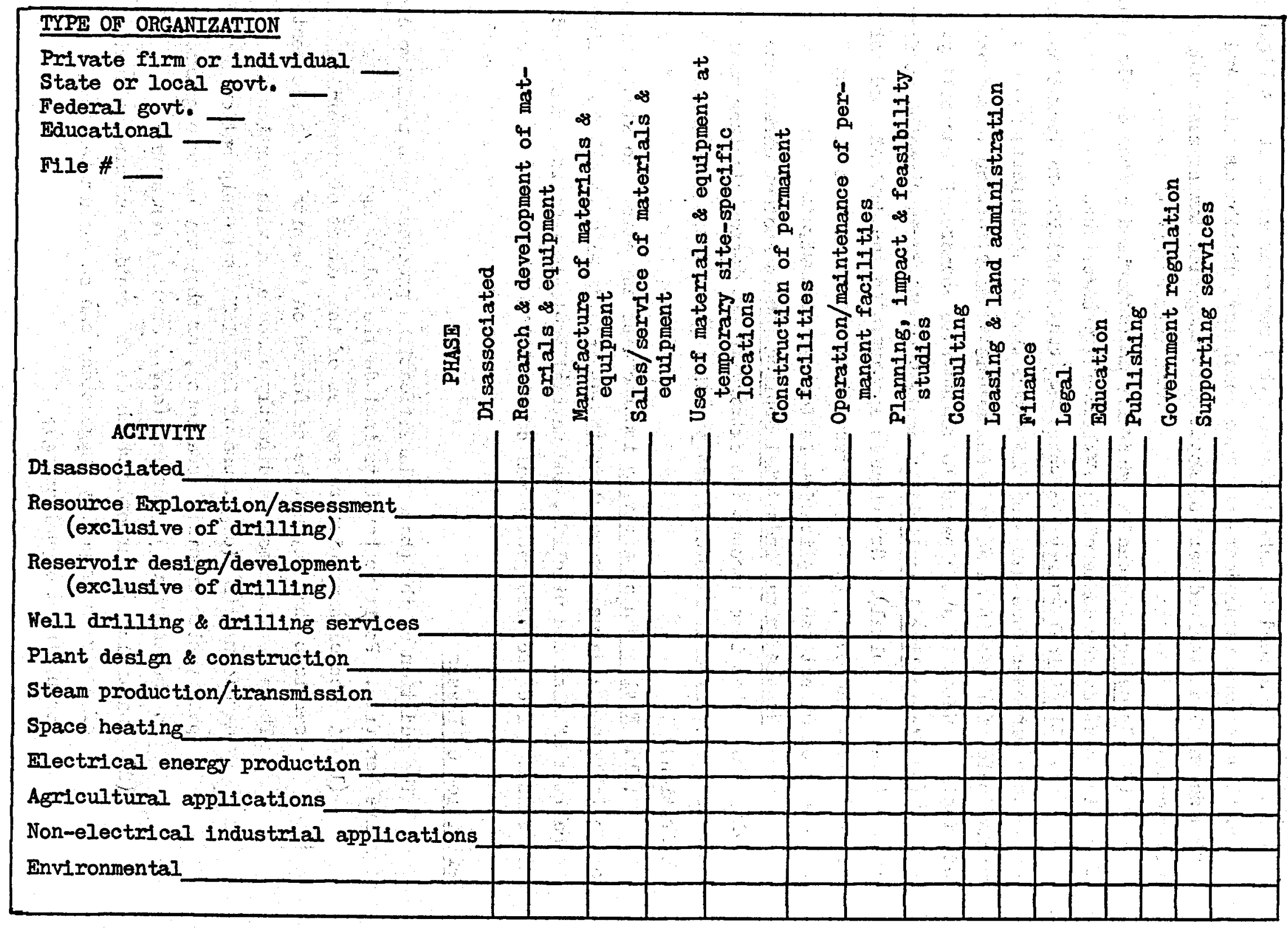


this activity does tend to make the associated manpower explicit. Ambiguity creeps in when some respondents may have considered steam production and transmission as an implied part of reservoir design and development and/or space heating.

(7) Space heating can be generally characterized by the development of heating systems for commercial, public, and private use.

(8) Electrical energy production applies basically to operation and maintenance manpower necessary for the production of electricity for commercial sale, for use in an adjunct commercial project, or for a project test facility which is anticipated to demonstrate commercial feasibility.

(9) Agricultural application contains any efforts directed at food growing (plant or animal). Greenhouses appear to be the dominant mode of this activity. However, it is important to note that at this time any assessment of direct use application is tenuous at best.

(10) Nonelectrical industrial application is another direct use activity that takes into account the extraction of by-products from the resource (e.g., mineral recovery) and processing functions (e.g., food dehydration).

(11) Environmental activity incorporates any effort to study, monitor, establish standards, or regulate the quality of air, water, the surrounding habitat of fish and wildlife, and natural geologic features associated with existing and proposed geothermal developments.

\section{Definition of Phases}

The addition of the phase classifications produces both positive and negative benefits. Positive benefits include the following:

(1) A much clearer picture emerges of the extent of supporting services that may not be performed on the site of development. These services may be directly associated with particular development(s) (e.g., use of materials and equipment on temporary site specific locations), or they may be more geared to the industry in general (e.g., applied research);

(2) Quantities of manpower which do not require extended efforts of analysis or policy suggestions can be eliminated (e.g., consulting and publishing); 
(3) The overall picture of manpower distribution in the geothermal industry is greatly enhanced because of the more precise taxonomy. The negative factors are as follows:

(1) The use of the activity-phase matrix greatly complicates the analysis. It is more time consuming to classify responses and requires considerably more computer work;

(2) Some redundancy is created (e.g., construction of permanent facilities and plant design and construction);

(3) Some subjective judgment is required on the part of the investigator in order to fit some responses into the matrix.

This explanation of the activity-phase matrix approach is not intended for purposes of advocating a general method. The primary purpose is to demonstrate what had to be done after the fact (1.e., after the first initial mailing) in order to get a clearer picture of manpower distribution in the industry. Additionally, it should not be interpreted that each phase category is of equal precision. Particular attention should be paid to the definitions which demonstrate that some categories are much more broadly defined than others. This was necessary in order to avoid constructing a matrix of unmanageable proportions. The definitions used in classifying the phases of development are as follows:

(1) Disassociated. See previous definttion.

(2) Research and development of materials, equipment, and methods refers to (a) basic research, especially in the geophysical and geochemical areas. This effort is primarily conducted in higher education research programs. It also includes (b) applied research which is geared toward solving particular technological problems, especially as spelled out by D.O.E. priorities in the industry, and (c) efforts aimed at predicting where the resource occurs and reservoir performance, l.e., computer and physical modeling.

(3) Manufacture of materials and equipment incorporates the physical production of a product and the design and technical support functions. Most respondents indicate activity in the area of different types of turbines, well head systems, and heat exchanger components. This serlously limits any inference from this category because of omitted elements of the manufacturing sector. 
(4) Sales and service of materials and equipment is another area of limited inference because of the small number of respondents and their association with only a few of the activities.

(5) Use of materials and equipment in temporary site specific Iocations includes efforts to inventory resources, such as geological, geophysical, or geochemical surveys. Temporary test facilities and drilling are also contained in this phase.

(6) Construction of permanent facilities contains electric (power plants), direct use (agricultural and processing), and supporting (steam gathering systems) activities.

(7) Operation and maintenance of permanent facilities applies to all categories in (b) above.

(8) Planning, impact, and feasibility studies. This phase embraces informational and program research and evaluation, policy research, user surveys, and analysis for scenario development.

(9) Consulting takes into account work done in both the public and private sectors. This category appears to be predominantly composed of single person operations with a few firms composed of several consultants. One marked problem in the classification used is the inability to identify the legal and finance phases with consulting work.

(10) Leasing and land administration. In the private sector one explicit characteristic is property acquisition for clients. In the public sector this is an area of major involvement for government agencies.

(11) Finance is a minor area that includes joint ventures, raising investment funds, and evaluating investment ventures.

(12) Legal is another minor category. Specific responses eoncerns environmental and tax codes, the development of laws concerning the resource, and leasing.

(13) Education. This phase contains only a small quantity of person months and is characterized by teaching and supportive research. Though it is not possible to strongly infer from the structure of this study, It appears that much of the research conducted in higher education is carried over into teaching and training research assistants.

(14) Publishing refers to books, maps, magazines, directories, and general information dissemination. 
(15) Government regulation. This function includes a variety of reporting, review, evaluation, inspection, certification, coordinating, monitoring, and permitting activities.

(16) Supporting services. This category is a general catchall but specifically includes management and administrative support functions, data processing, clerical work, accounting, and contract work. 
Appendix B

OCCUPATIONAL PROFTIES FROM

PROJECT INDEPEENDENCE 
Geothermal Manpower Estimates

This section presents the assumptions and factors used to estimate manpower requirements for geothermal. Two types of geothermal energy processes are presented: ( 1 ) dry-steam and (2) brine or hot water. The manpower estimates were prepared by Bechtel Corporation for use in the FEA Project Independence Blueprint exercise.

The manpower "building-block" estimates were developed around an assumed economically viable geothermal producing field having an installed capacity of $200 \mathrm{MW}$. To compute total manpower requirements the manpower building-block estimates presented in this section are multiplied by the number of plants derived. 
Manpower Est., Brine and Dry Steam

General Assumptions and Factors

$200 \mathrm{MW}_{\mathrm{e}}$ (net) Plant

I. Utility companies are presently demanding that the 20 percent excess capacity be developed in the geothermal field as a hedge against uncertainty and premature failure of wells. This may not be required in the 1980's with better knowledge of the energy source. Manpower estimates presented on the following pages for (a) reservoir design and development and (b) gathering systems should have been increased by 20 percent for this excess capacity requirement.

II. Manpower estimates for clerical and administrative personnel represent five percent of total manpower. 
Manpower Est. Brine Resource (Only)

All Phases of Development

$200 \mathrm{MW}_{e}$ (net) Plant

I. Scope of Work:

All phases of development of a hot-brine resource for production of electrical energy including:

a) Resource Exploration and appraisal

b) Reservoir design and development

c) Conversion system design and construction

d) Operation and maintenance

II. Assumptions:

a) Manpower requirements for exploration, and discovery of dry-steam resources will be twenty (20) times that required for the same capacity of brine resource.

b) Manpower requirements for reservoir design and development will be proportional to the required number of wells, and will be the same for either dry steam or brine resources.

c) Manpower requirements for the conversion system design and construction of a brine-type power plant will be $40 \%$ greater than for a dry-steam plant.

d) Manpower requirements for operation and maintenance of a brine plant will be at least $25 \%$ higher.

e) For each $200 \mathrm{MW}_{e}$ plant there will be:

52 development wells

26 reinjection wells

assuming water temperature of 382 degrees - 200 psi. 
Manpower Est. Brine Resource (Only)

Resource Exploration and Appraisal, $200 \mathrm{MWe}$ (net) Plant

Scope of Work:

Conduct initial gross reconnaissance to identify prospects; conduct local geological/geophysical investigations to discriminate among prospects and identify specific resource to be developed; develop necessary rights and leases to permit physical development; sink necessary exploratory wells to determine chemical and thermal properties of the geothermal fluid.

Assumptions:

1. Explore 4 prospective areas to find 1 desirable prospect (Physical measurement).

2. Drill 16 drillable prospects to find 1 field of 200 wh electric minimum initial capacity.

3. Average well capacity is $5 \mathrm{Me}$ per well.

4. Drill 2 exploratory holes per drilled prospect.

5. Take 60 calendar days per exploratory hole.

6. Have 4 drill rigs drilling for 18 months.

7. Twenty-four month exploration and drilling program to find $200 \mathrm{MW}_{\mathrm{e}}$

Manpower (In Man Years)

Resource Exploration \& Appraisal

Quantity

Required

$$
\begin{array}{r}
3 \\
2 \\
2 \\
4 \\
12 \\
8 \\
4
\end{array}
$$

2
SIII1

Geologist

Geophysicist

Landman

Drill rig foreman

Driller

Laborer

Truck Driver

Geochemist
First

Year

3

2

2

2

6

4

2

1
Second Year

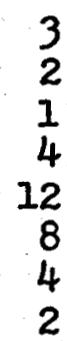


Manpower Est., Dry-Steam Resource (Only)

Reservoir Design \& Development

$200 \mathrm{MW}_{e}$ (net) Plant

\section{Scope of Works}

Construct reservoir model; locate and drill all production wells and all reinjection wells; perform well-logging and preliminary well tests; case, cement, and complete all wells thru the well-head valves to complete shut-in. Conduct well-flow tests, chemical sampling, etc.

\section{Assumptions:}

a) Total initial production wells $=34$ wells (provides $20 \%$ spare capacity)

b) Drilling time $=60$ work days/well (average)

c) Working drill rigs $=5$ (average)

d) Average well depth $=5000 \mathrm{ft}$.

Quantity

Required

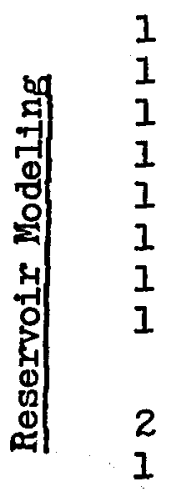

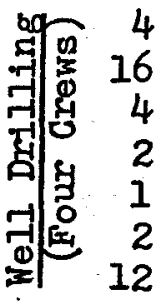

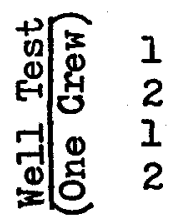

\section{Skilled Personnel}

Reservoir Engineer

Geologist (Theoretical)

Geophysicist

Hydrologist

Geochemist

Mathematician (Applied)

Mathematical Technician

Draftsman

Geologist (Core-Logger)

Drilling Superintendent

Rig Foreman

Driller

Pipe-Fitter

Welder

Crane Operator

Truck Driver

Laborer

Reservoir Engineer

Mech. Engineer

Geochemist

Mechanical Technician
Nan Years

\begin{tabular}{ll}
\hline$(1.0$ yr. & $(0.2$ yr. \\
lst Year & 2nd Year \\
\hline
\end{tabular}

$\begin{array}{ll}.75 & 0 \\ .3 & 0 \\ .3 & 0 \\ .3 & 0 \\ .3 & 0 \\ .75 & 0 \\ .75 & 0 \\ .25 & 0\end{array}$

$\begin{array}{ll}2.0 & 0.4 \\ 1.0 & 0.2\end{array}$

4. 0

0.8

16.0

4.0

3.2

2.0

1.0

2.0

12.0

0.8

0.4

0.2

0.4

2.4

0.75

1.50

0.75

1.50
0.2

0.4

0.2

0.4 
Manpower Est. Dry-Steam Resource (Only)

Design \& Construct Conversion System $200 \mathrm{MWe}$ (net) Plant

\section{Scope of Work:}

Design, procure, construct, test, and start-up the entire above-ground plant, whose limits extend from the well-head valve discharge flange thru the gathering and reinjection system, thru the power generation plant, and thru the switch-yard. It does not include any electric power transmission facilities.

\section{Gathering System:}

Assume: a) 34 producing wells

b) 34,560 feet pipe 16" thru 36"

c) 1 year design, procure, and construct program: 4 month design, 8 month construct.

d) well-head valve to last centrif.

\begin{tabular}{|c|c|c|}
\hline $\begin{array}{l}\text { Quantity } \\
\text { Required }\end{array}$ & Skilled Personnel & $\begin{array}{c}\text { Man Years } \\
\text { Total }\end{array}$ \\
\hline $\begin{array}{l}2 \\
1 \\
1 \\
1 \\
5\end{array}$ & $\begin{array}{l}\text { Mech. Engineer (Design) } \\
\text { Civil Engineer (Design) } \\
\text { Draftsman (Designer Quality) } \\
\text { Draftsman } \\
\text { Route Surveyor (0.25) }\end{array}$ & $\begin{array}{l}0.7 \\
0.33 \\
0.33 \\
0.33 \\
1.25\end{array}$ \\
\hline $\begin{array}{l}1 \\
2 \\
6 \\
4 \\
2 \\
4 \\
2 \\
4 \\
2 \\
6 \\
1 \\
2\end{array}$ & $\begin{array}{l}\text { Civil Engineer (Construction) } \\
\text { Foreman }(0.7) \\
\text { Pipe Fitter (0.5) } \\
\text { Nelder } \\
\text { Carpenter } \\
\text { Concrete Worker } \\
\text { Dozer-Operator } \\
\text { Truck Driver } \\
\text { Crane Operator } \\
\text { Insulation Installer ( } 864 \mathrm{wk}) \\
\text { Inspector (construction) } \\
\text { Inspector (non-destruct, testing) }\end{array}$ & $\begin{array}{l}0.7 \\
1.4 \\
3.0 \\
2.0 \\
1.0 \\
2.0 \\
1.0 \\
2.0 \\
1.0 \\
0.5 \\
0.58 \\
0.50\end{array}$ \\
\hline
\end{tabular}

\section{Power-house:}

Assume:

a) 2-100 $\mathrm{MW}_{\mathrm{e}}$ (net) Generating Units

b) 1.5 year design schedule

c) 3 year construction schedule

d) 24 month delivery schedule on each $\mathrm{T} / \mathrm{s}$ set 
TABIE B-3 (Cont.)

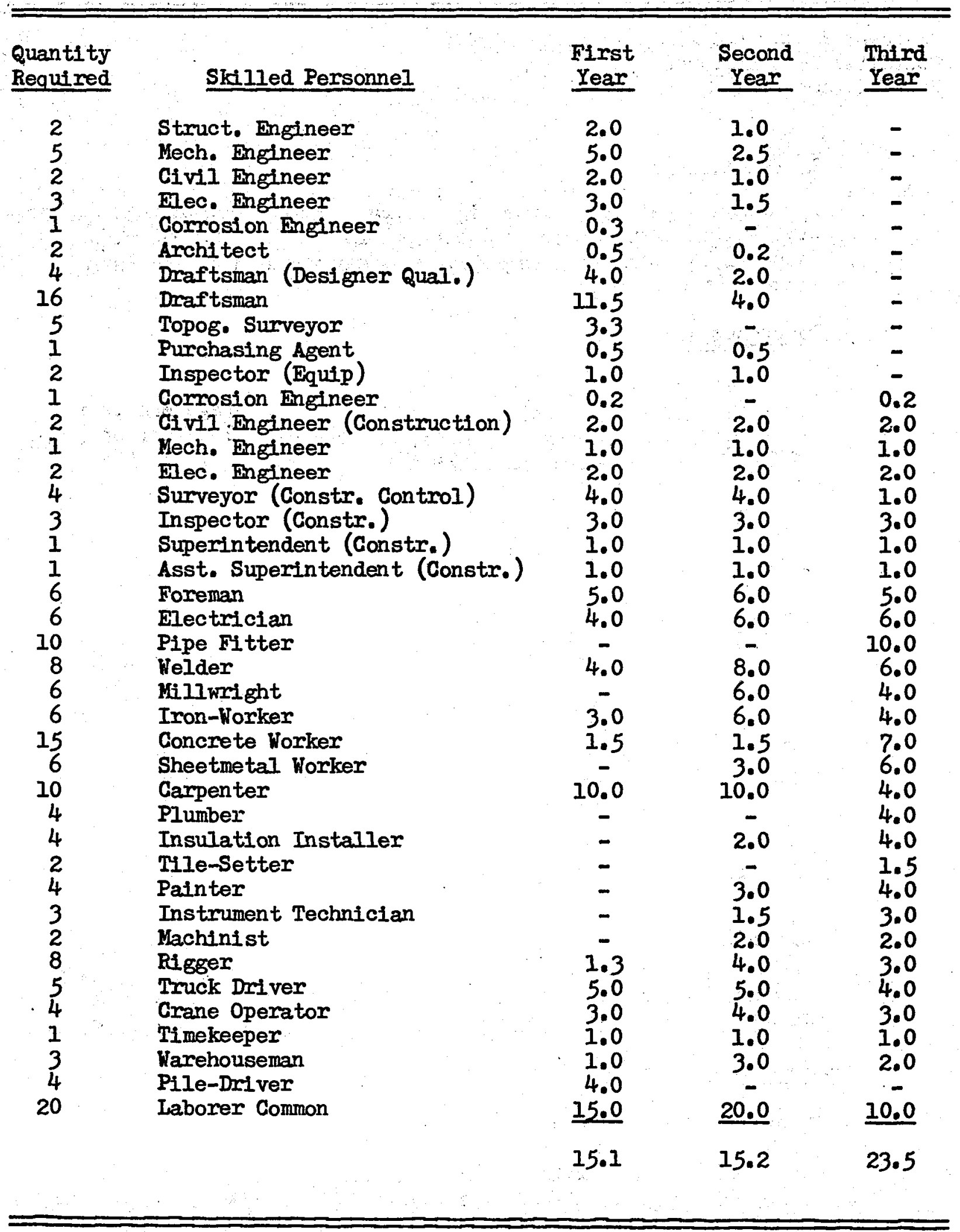


Manpower Est. Dry-Steam Resource (Only) Operation \& Maintenance $200 \mathrm{MWF}_{\mathrm{e}}$ (net) Plant

\section{Scope of Works}

Operate and maintain the entire energy recovery system and conversion system thru the 35 year design life of the $200 \mathrm{MW}$ plant. Assume 2 wk. planned outage/ys, + 30 day planned outage each 3 years, for each unit.

II. Powerhouse:

Quantity

Reguired

$\begin{array}{ll}\text { म् } & 1 \\ 0 & 3 \\ \text { है } & 9\end{array}$

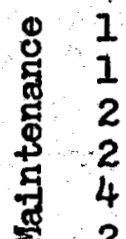

\& 3

专 3

क्ष
Skilled Personnel

Plant superintendent (oper.)

Shift Foreman

Plant Operator

Mech. Engr. (Turb. Specialist)

Corrosion Engineer

Instrument Technician

Foreman

Millwright

Machinist

Pipefitter

Flectrician

Insulation Installer

Painter

Rigger

Crane Operator

Laborer
Average Man Years

Per Year of Plant Life

III. Gathering System:

Quantity

Required

4
5
Skilled Personnel

Field Operator
1

3

0.1

0.1

0.5

0.2

0.2

0.2

0.3

0.2

0.2

0.2

0.1

0.1

0.2

Average Man Years

Per Year of

Plant Iife

1 
TABLE B-4 (Cont.)

III. Gathering System (Cont.)

Quantity Required

Skilled Personnel

Foreman

Pipefitter

Welder

Insulation Installer

Crane Operator

Civil Engineer (Design)

Mech. Fringineer (Design)

Draftsman

Civil Engineer (Construction)

Foreman

Pipefitter

Welder

Carpenter

Conc. Worker

Dozer Operator

Crane Operator

Truck Driver

Insulation Installer

Inspector (Constr.)
Average Man Years

Per Year of

Plant Iife

0.1

0.2

0.1

0.2

0.1

0.2

0.5

1.5

1.0

0.5

0.1

0.2

0.5

0.5

0.5

0.1 


\section{Appendix C}

\section{OCCUPATION PROFIIES}

DEVELOPED FROM THIS STUDY 
TABLE C-1. OCCUPATIONAL PROFIIIS FOR FIRMS

INVOLVED IN EXPLORATION AND

APPRAISAL OF THE RESOURCE

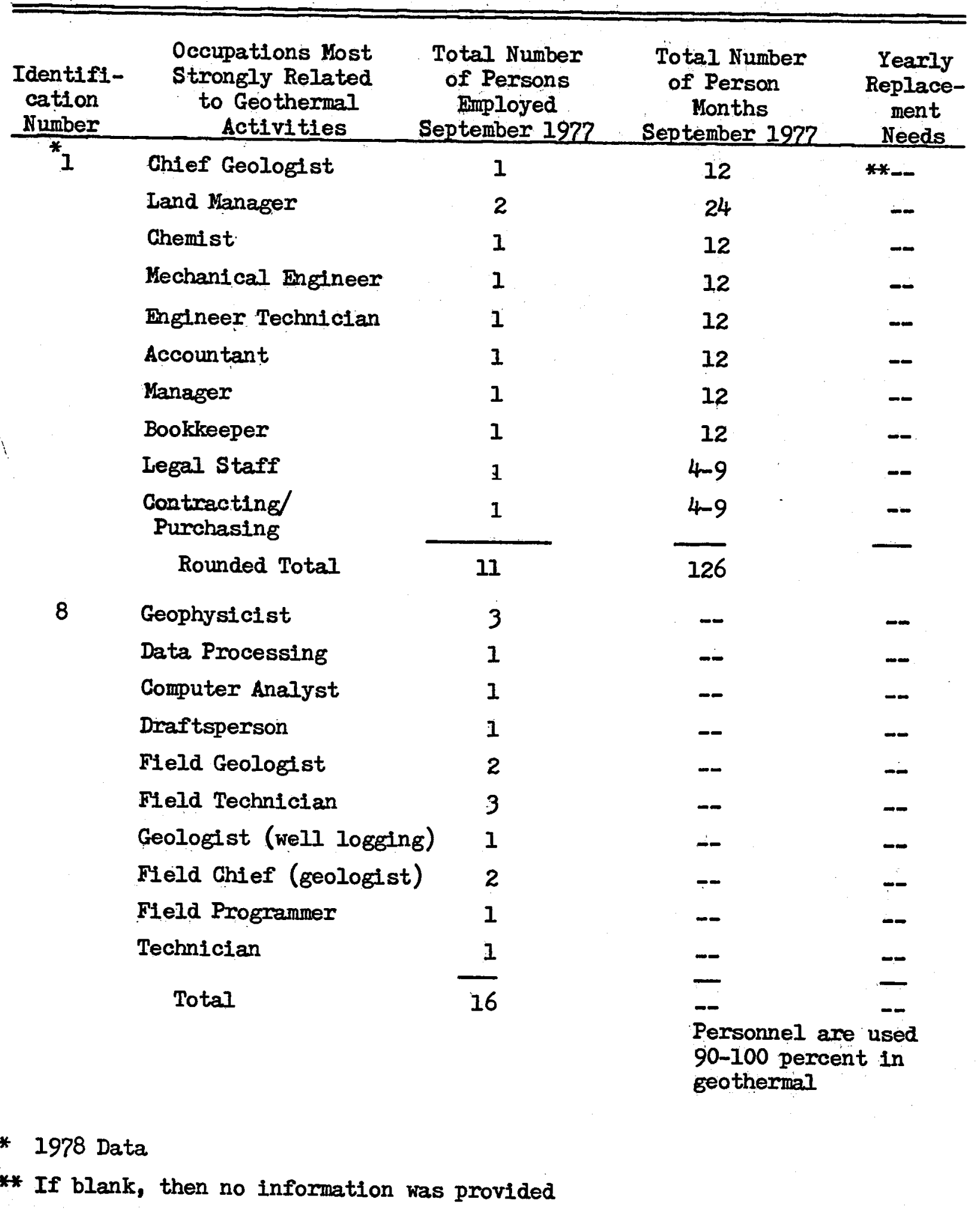


TABLE C-I. (CONTINUED)

\begin{tabular}{|c|c|c|c|c|}
\hline $\begin{array}{l}\text { Identifi- } \\
\text { cation } \\
\text { Number } \\
\end{array}$ & $\begin{array}{c}\text { Occupations Most } \\
\text { Strongly Related } \\
\text { to Geothermal } \\
\text { Activities }\end{array}$ & $\begin{array}{c}\text { Total Number } \\
\text { of Pe rsons } \\
\text { Employed } \\
\text { September } 1972\end{array}$ & $\begin{array}{l}\text { Total Number } \\
\text { of Person } \\
\text { Months } \\
\text { September } 1977\end{array}$ & $\begin{array}{l}\text { Yearly } \\
\text { Replace- } \\
\text { ment } \\
\text { Needs }\end{array}$ \\
\hline \multirow[t]{4}{*}{10} & Geophysicist & $\quad 10$ & -- & -- \\
\hline & Geologist & 10 & -- & - \\
\hline & Environmental Tech. & 8 & $\underline{-}$ & $=$ \\
\hline & Total & 28 & $\begin{array}{l}\text { Used } 85 \% \text { of } \\
\text { the time in } \\
\text { geothermal }\end{array}$ & \\
\hline \multirow[t]{4}{*}{16} & Land Use Personnel & 5 & 60 & -- \\
\hline & Geophysicist & 25 & - & - \\
\hline & Geologist & 5 & $=$ & $=$ \\
\hline & Total & 35 & 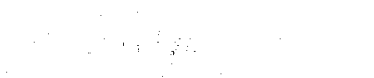 & \\
\hline \multirow{6}{*}{ *17 } & Geologist & 3 & - & - \\
\hline & Geochemist & 1 & - & - \\
\hline & Draftsman & 4 & - & - \\
\hline & Landman : & 4 & - & - \\
\hline & Environmental Planner & 2 & - & - \\
\hline & Drilling Engineer & 1 & - & $-\infty$ \\
\hline \multirow[t]{4}{*}{ 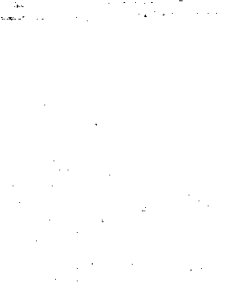 } & Administrative Engineer & er & - & - \\
\hline & Fleld Superintendent & 3 & -- & - \\
\hline & Other & $\frac{5}{24}$ & $=$ & $=$ \\
\hline & Total & 24 & & \\
\hline \multirow[t]{8}{*}{19} & Geologist & 2 & 24 & - \\
\hline & Geophysicist & 1 & 12 & - \\
\hline & Drilling & 1 & 6 & - \\
\hline & Petroleum Engineer & 1 & 6 & -- \\
\hline & Mechanical Engineer & 1 & 3 & -- \\
\hline & Land Manager & 2 & 18 & 1 \\
\hline & Legal & 1 & $\underline{6}$ & $=$ \\
\hline & Total & 9 & 75 & 1 \\
\hline
\end{tabular}


TABLE C-1. (CONTTNUET)

\begin{tabular}{|c|c|c|c|c|}
\hline $\begin{array}{l}\text { Identifi- } \\
\text { cation } \\
\text { Number } \\
\end{array}$ & $\begin{array}{c}\text { Occupations Most } \\
\text { Strongly Related } \\
\text { to Geothermal } \\
\text { Activities }\end{array}$ & $\begin{array}{c}\text { Total Number } \\
\text { of Persons } \\
\text { Employed } \\
\text { September } 1977\end{array}$ & $\begin{array}{c}\text { Total Number } \\
\text { of Person } \\
\text { Months } \\
\text { September } 1977 \\
\end{array}$ & $\begin{array}{l}\text { Yearly } \\
\text { Replace- } \\
\text { ment } \\
\text { Needs } \\
\end{array}$ \\
\hline \multirow[t]{15}{*}{33} & Geologist & 3 & 36 & -- \\
\hline & Geophysicist & 2 & $\cdots$ & -- \\
\hline & Geochemist & 1 & 12 & -- \\
\hline & Manager & 1 & 12 & - \\
\hline & Draftsman & 2 & 24 & -- \\
\hline & Iand Manager & 1 & 12 & $-\infty$ \\
\hline & Land Secretary & 1 & 12 & - \\
\hline & Land Draftsman & 1 & 12 & $-\infty$ \\
\hline & Financial Analyst & 1 & 12 & -- \\
\hline & Exploration Tech. & 2 & 24 & -- \\
\hline & Drilling Supervisor & 1 & 12 & - \\
\hline & Attorney & 2 & $3-12$ & -- \\
\hline & Accounting Staff & 2 & $3-12$ & - \\
\hline & Secretary & 2 & 12 & $=$ \\
\hline & Rounded Total & 22 & 230 & - \\
\hline
\end{tabular}


TABLE C-2. OCGUPATIONAL PROFIIES FOR FIRYS INVOLVED IN DRTILING ACTIVITIBS

\begin{tabular}{|c|c|c|c|c|}
\hline $\begin{array}{l}\text { Identifi- } \\
\text { cation } \\
\text { Number } \\
\end{array}$ & $\begin{array}{c}\text { Occupations } \\
\text { Strongly Related } \\
\text { to Geothermal } \\
\text { Activities }\end{array}$ & $\begin{array}{c}\text { Total Number } \\
\text { of Persons } \\
\text { Employed } \\
\text { September } 1972\end{array}$ & $\begin{array}{c}\text { Total Number } \\
\text { of Person } \\
\text { Nonths } \\
\text { September } 1972\end{array}$ & $\begin{array}{c}\text { Yearly } \\
\text { Replace- } \\
\text { ment } \\
\text { Needs } \\
\end{array}$ \\
\hline$* 7$ & Assistant Driller & 9 & 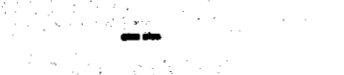 & 6 \\
\hline & Driller Foreman & 9 & - & 6 \\
\hline & Job Foreman & 9 & $=$ & $\underline{0.5}$ \\
\hline & Total & 27 & & 12.5 \\
\hline 18 & Drilling Foreman & 4 & - & - \\
\hline$\ldots$ & Driller & 4 & -- & - \\
\hline & Derrickman & 4 & - & - \\
\hline & Motorman & 4 & - & - \\
\hline & Drilling Helper & 8 & $=$ & $=$ \\
\hline & Total & 24 & & . \\
\hline$* 22$ & Driller & 4 & 9 & - \\
\hline & Driller Helper & 8 & 9 & $=$ \\
\hline & Total & 12 & 18 & \\
\hline
\end{tabular}

* 1978 Data 
TABLE C-3. OCCUPATIONAL PROFILES FOR FIRMS INVOLVED IN RESERVOIR DEVEHOPNENT, POWER PLANT ENGINEERING, AND DESIGN

\begin{tabular}{|c|c|c|c|c|}
\hline $\begin{array}{l}\text { Identifi- } \\
\text { cation } \\
\text { Number } \\
\end{array}$ & $\begin{array}{c}\text { Occupations } \\
\text { Strongly Related } \\
\text { to Geothermal } \\
\text { Activities }\end{array}$ & $\begin{array}{l}\text { otal Number } \\
\text { of Persons } \\
\text { Employed } \\
\text { ptember } 1977\end{array}$ & $\begin{array}{c}\text { Total Number } \\
\text { of Person } \\
\text { Months } \\
\text { September } 1977 \\
\end{array}$ & $\begin{array}{r}\text { Year } \\
\text { Repla } \\
\text { men- } \\
\text { Need } \\
\end{array}$ \\
\hline \multirow[t]{18}{*}{5} & Environmental & & & \\
\hline & Geologist & 2 & - & -- \\
\hline & Area Planner & 1 & - & -- \\
\hline & Air Quallty Tech. & 1 & - & - \\
\hline & Noise Pollution & 1 & - & - \\
\hline & Archeologist & 1 & - & - \\
\hline & Engineer. & & & \\
\hline & Mechanical & 4 & - & -- \\
\hline & Process (Mining/metals & 1 & - & - \\
\hline & Management & & & \\
\hline & Manager & 1 & - & - \\
\hline & Lawyer & 1 & $-\infty$ & - \\
\hline & Procurement Spec. & 1 & -- & - \\
\hline & Administrative & 6 & - & - \\
\hline & Secretarial & 4 & - & - \\
\hline & Comptroller & 12 & - & - \\
\hline & Asst. Comptroller & $\underline{12}$ & $=$ & $=$ \\
\hline & Total & 48 & & \\
\hline \multirow[t]{10}{*}{24} & Mechanical Engineer & 8 & - & - \\
\hline & Technical Assistant & 3 & -- & - \\
\hline & $\begin{array}{l}\text { Chemical Processing } \\
\text { Engineer }\end{array}$ & 2 & -- & - \\
\hline & Plant Design & 1 & - & - \\
\hline & Architect & 3 & - & - \\
\hline & Hectrical Engineer & 9 & - & - \\
\hline & Project Manager & 2 & -- & - \\
\hline & Civil/structural Engineer & 3 & -- & - \\
\hline & Instrumentation & $\frac{1}{10}$ & $=$ & $=$ \\
\hline & Total & 32 & & \\
\hline
\end{tabular}


TABLE C-3. (CONTTNUED)

\begin{tabular}{|c|c|c|c|c|}
\hline $\begin{array}{l}\text { Identifi- } \\
\text { cation } \\
\text { Number } \\
\end{array}$ & $\begin{array}{c}\text { Occupations } \\
\text { Strongly Related } \\
\text { to Geothermal } \\
\text { Activity }\end{array}$ & $\begin{array}{c}\text { Total Number } \\
\text { of Persons } \\
\text { Hmployed } \\
\text { September } 1972\end{array}$ & $\begin{array}{c}\text { Total Number } \\
\text { of Person } \\
\text { Months } \\
\text { September } 1972\end{array}$ & $\begin{array}{l}\text { Yearly } \\
\text { Replace- } \\
\text { ment } \\
\text { Needs } \\
\end{array}$ \\
\hline \multirow[t]{4}{*}{29} & Head Geologist & 1 & .12 & - \\
\hline & Staff Geologist & 5 & 60 & - \\
\hline & Geological Draftsman & 1 & 12 & -- \\
\hline & Drilling Head & 1 & 12 & -- \\
\hline & Drililing Engineer & 1 & 12 & - \\
\hline & Tool Pusher & 2 & 12 & - \\
\hline & Mechanical Engineer & 1 & 12 & - \\
\hline & Geological Engineer & 1 & 12 & -- \\
\hline & Production Foreman & 1 & 12 & $-\infty$ \\
\hline & Construction Foreman & 1 & 12 & - \\
\hline & Contract Support & 2 & 24 & -- \\
\hline & Pipeline Technician & 3 & 36 & -- \\
\hline & Reservolr Engineer & 1 & 12 & -- \\
\hline & Land Manager & 1 & 12 & - \\
\hline & Comptroller & 3 & 36 & -- \\
\hline & Landman & 1 & 12 & $=$ \\
\hline & Total & 26 & 312 & \\
\hline
\end{tabular}


148

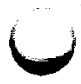


Appendix D

MANPOWER FOREGAST BY

SPECIFIC OCCUPATIONS 
TABLE D-1. RESOURCE EXPLORATION AND ASSESSMENT

\begin{tabular}{|c|c|c|c|c|c|c|c|c|c|}
\hline & \multirow{2}{*}{\multicolumn{2}{|c|}{$\begin{array}{l}\text { Summed Total of Individuals } \\
\text { from Surveyed FIrms and } \\
\text { Project Independence }\end{array}$}} & \multirow{2}{*}{$\begin{array}{c}\text { Forecasting } \\
\text { Coefficient } \\
\text { (percent) }\end{array}$} & \multicolumn{4}{|c|}{$\begin{array}{c}\text { Derl ved New Employment Istimated from } \\
1980-1985\end{array}$} & \multicolumn{2}{|c|}{$\begin{array}{l}\text { Forecasted Growth } \\
\quad 1980-1990 \\
\end{array}$} \\
\hline & & & & 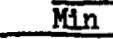 & $\operatorname{Max}$ & Min & $\operatorname{Max}$ & 正n & $\operatorname{Max}$ \\
\hline \multicolumn{10}{|l|}{ Solent1sts/Engineers } \\
\hline $\begin{array}{l}\text { Geologist } \\
\text { Geophysicist } \\
\text { Geochemist } \\
\text { Mechanical Engineer } \\
\text { Drilling Engineer } \\
\text { Petroleum Engineer }\end{array}$ & Subtotal & $\begin{array}{r}32 \\
43 \\
5 \\
2 \\
2 \\
1 \\
85\end{array}$ & $\begin{array}{r}3.61 \\
4.86 \\
.56 \\
.23 \\
.23 \\
.11\end{array}$ & $\begin{array}{r}427 \\
574 \\
67 \\
27 \\
27 \\
13 \\
1135\end{array}$ & $\begin{array}{r}1167 \\
1572 \\
181 \\
74 \\
74 \\
37 \\
3105\end{array}$ & $\begin{array}{r}1338 \\
1802 \\
208 \\
85 \\
85 \\
42 \\
3560\end{array}$ & $\begin{array}{r}3664 \\
4932 \\
568 \\
233 \\
233 \\
116 \\
9746\end{array}$ & $\begin{array}{r}1764 \\
2375 \\
274 \\
112 \\
112 \\
56 \\
4693\end{array}$ & $\begin{array}{r}4831 \\
6504 \\
749 \\
308 \\
308 \\
154 \\
12854\end{array}$ \\
\hline$\frac{\text { Administrative Management/ }}{\text { Glerical }}$ & Subtotal & 11 & 1.24 & 147 & 401 & 460 & 1258 & 606 & 1659 \\
\hline \multicolumn{10}{|l|}{ Specialized Management } \\
\hline $\begin{array}{l}\text { Contracting/Purchasing } \\
\text { Flnanclai Analyst } \\
\text { Accounting } \\
\text { Legal } \\
\text { Land Management }\end{array}$ & Subtotal & $\begin{array}{r}1 \\
1 \\
3 \\
4 \\
\frac{11}{20}\end{array}$ & $\begin{array}{r}.11 \\
.11 \\
.34 \\
.45 \\
1.24\end{array}$ & $\begin{array}{r}13 \\
13 \\
40 \\
53 \\
147 \\
266\end{array}$ & $\begin{array}{r}37 \\
37 \\
110 \\
146 \\
401 \\
731\end{array}$ & $\begin{array}{r}42 \\
42 \\
126 \\
167 \\
460 \\
837\end{array}$ & $\begin{array}{r}116 \\
116 \\
345 \\
457 \\
1258 \\
2292\end{array}$ & $\begin{array}{r}56 \\
56 \\
166 \\
220 \\
606 \\
1104\end{array}$ & $\begin{array}{r}154 \\
154 \\
455 \\
602 \\
1659 \\
3024\end{array}$ \\
\hline \multicolumn{10}{|l|}{ Technicians } \\
\hline $\begin{array}{l}\text { Englneering Techniclan } \\
\text { Computer Analyst } \\
\text { Data Processing } \\
\text { Draftsman } \\
\text { Exploration Technician } \\
\text { Environmental Technician }\end{array}$ & Subtotal & $\begin{array}{r}1 \\
2 \\
1 \\
9 \\
6 \\
10 \\
\frac{10}{29}\end{array}$ & $\begin{array}{r}.11 \\
.23 \\
.11 \\
1.02 \\
.68 \\
1.13\end{array}$ & $\begin{array}{r}13 \\
27 \\
13 \\
120 \\
80 \\
133 \\
386\end{array}$ & $\begin{array}{r}37 \\
74 \\
37 \\
330 \\
220 \\
\frac{365}{1063}\end{array}$ & $\begin{array}{r}42 \\
85 \\
42 \\
378 \\
252 \\
419 \\
1218\end{array}$ & $\begin{array}{r}116 \\
233 \\
116 \\
1035 \\
690 \\
1147 \\
3337\end{array}$ & $\begin{array}{r}56 \\
112 \\
56 \\
499 \\
332 \\
552 \\
1607\end{array}$ & $\begin{array}{r}154 \\
308 \\
154 \\
1365 \\
910 \\
1512 \\
4403\end{array}$ \\
\hline \multicolumn{10}{|l|}{ Others } \\
\hline \multirow[t]{2}{*}{$\begin{array}{l}\text { Laborer } \\
\text { Truck Driver }\end{array}$} & Subtotal & $\begin{array}{l}4 \\
\frac{2}{6}\end{array}$ & $\begin{array}{l}.45 \\
.23\end{array}$ & $\begin{array}{l}53 \\
27 \\
80\end{array}$ & $\begin{array}{r}146 \\
74 \\
220\end{array}$ & $\begin{array}{r}167 \\
\quad 85 \\
252\end{array}$ & $\begin{array}{l}457 \\
233 \\
690\end{array}$ & $\begin{array}{l}220 \\
\frac{112}{332}\end{array}$ & $\begin{array}{l}602 \\
\frac{308}{910}\end{array}$ \\
\hline & TOTAL & 151 & & 2014 & 5520 & 6327 & 17323 & 8342 & 22850 \\
\hline
\end{tabular}


TABLE D-2. DRTHIING

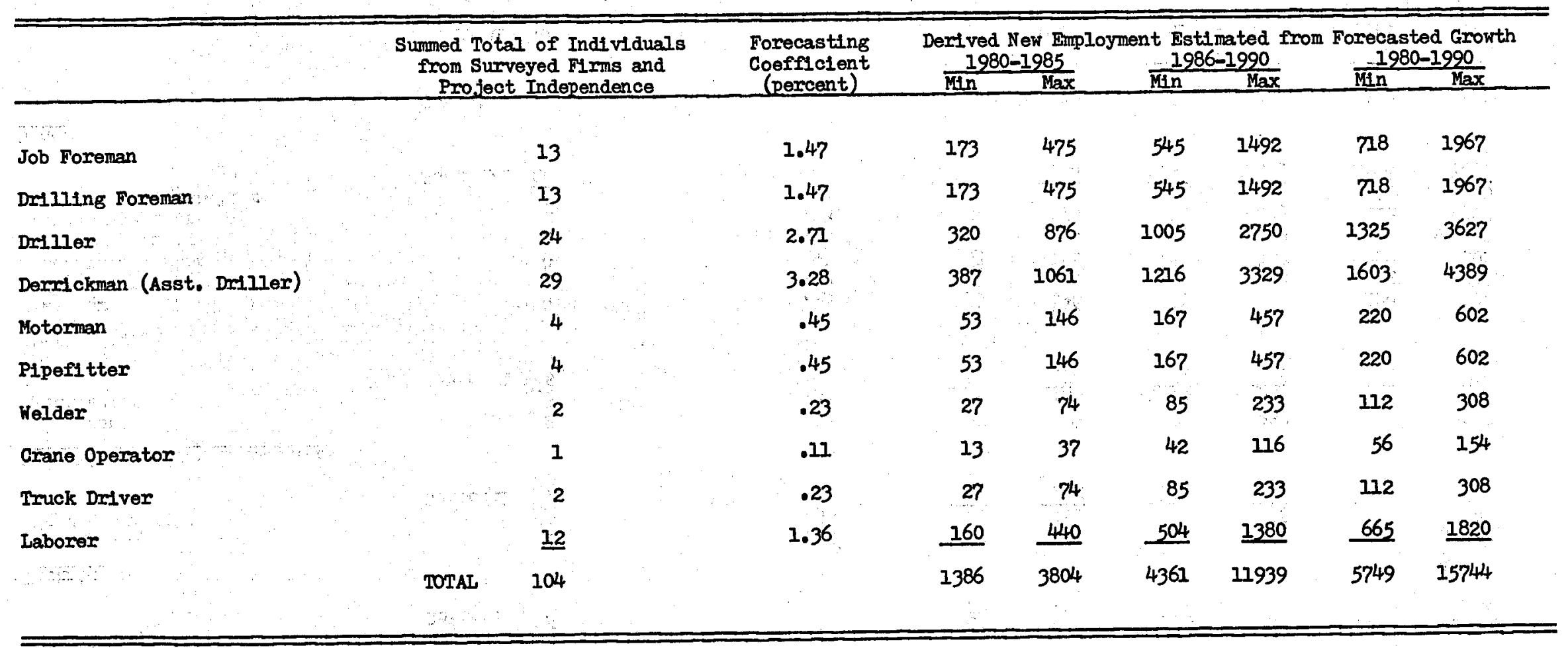


TABLE D-3. RESERVOIR FEED SYSTHM (Construction)

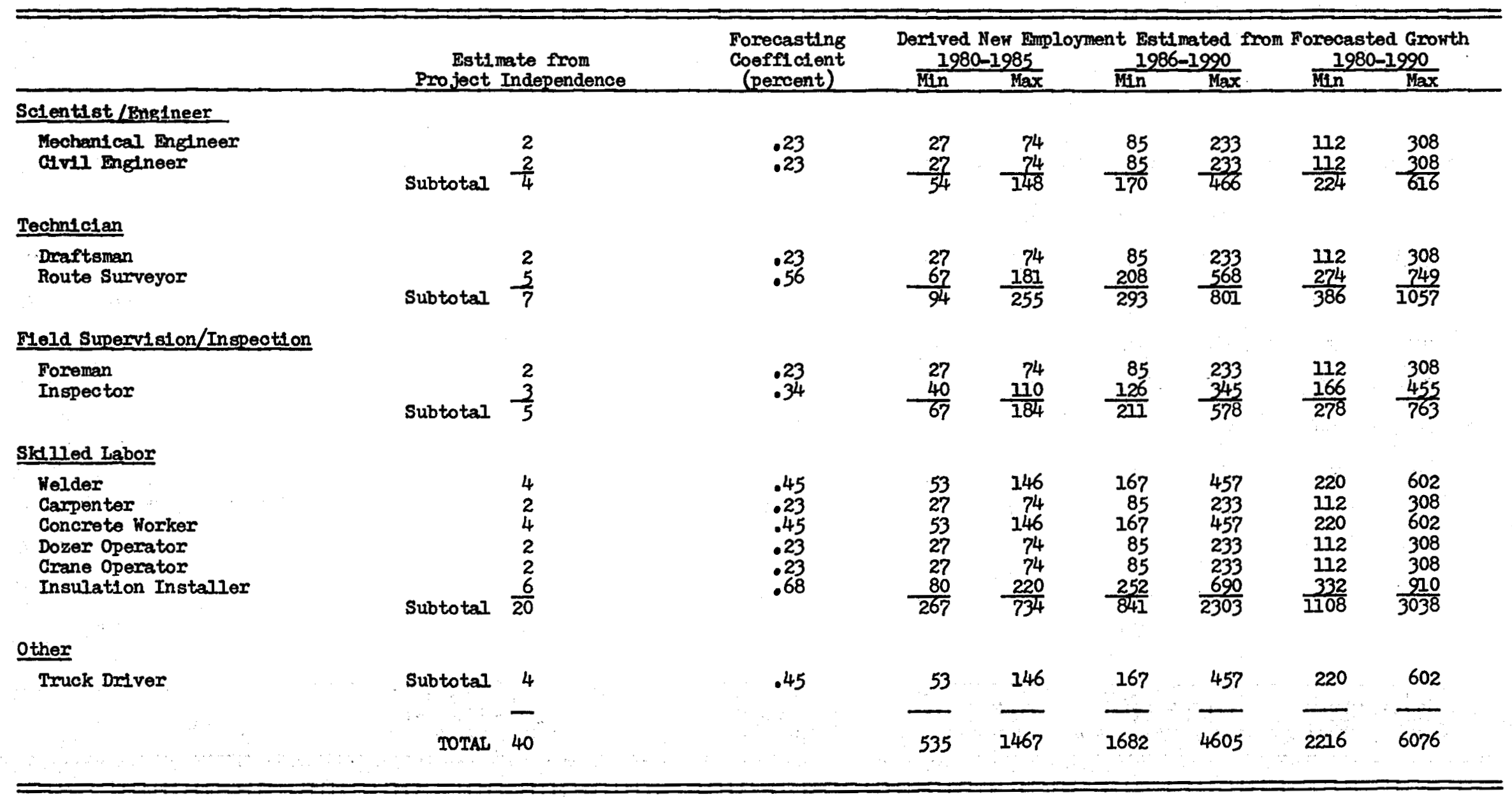


TAELE D-4. RESERVOIR FHED SYSTEMY (operation/maintenance)

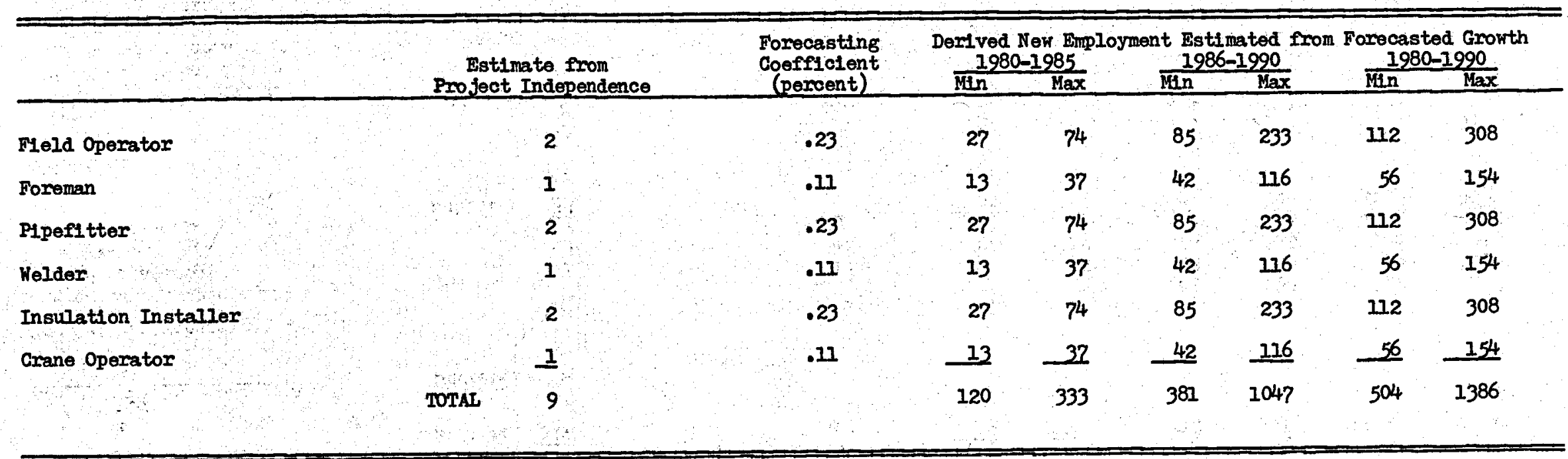


TABLE D-5. CONSTRUCTION OF POWER PLANTS

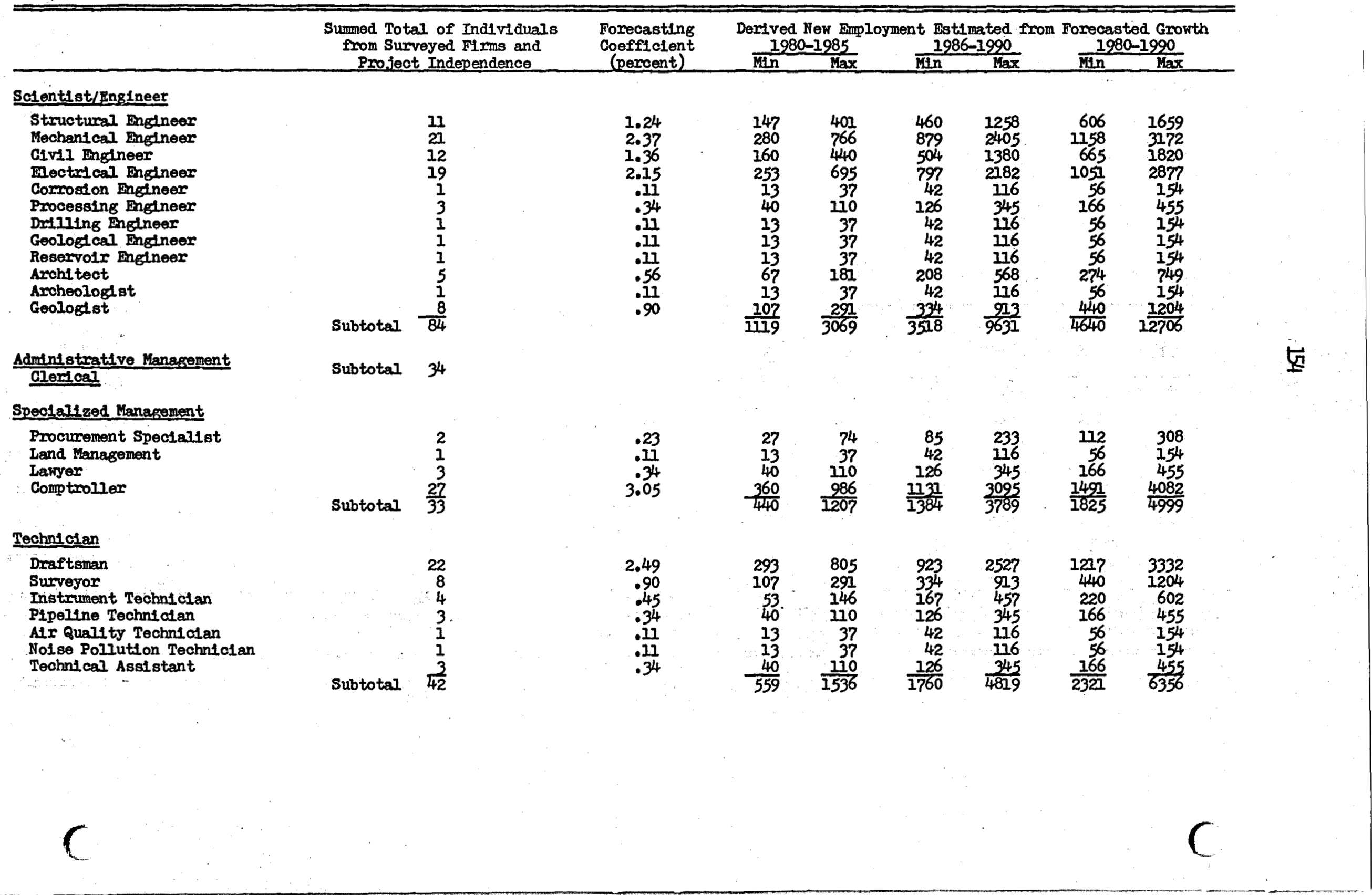


TABLE D-5. CONSTRUCTION OF POWER PLANIS (Cont.)

\begin{tabular}{|c|c|c|c|c|c|c|c|c|c|}
\hline \multirow{2}{*}{$\begin{array}{ll} \\
3\end{array}$} & \multirow{2}{*}{$\begin{array}{l}\text { Summed Total of Individuals } \\
\text { from Surveyed FI mins and } \\
\text { Project Independence }\end{array}$} & \multirow{2}{*}{$\begin{array}{l}\text { Forecasting } \\
\text { Coefficlent } \\
\text { (percent) }\end{array}$} & \multicolumn{4}{|c|}{$\begin{array}{c}\text { Derived New Employment Estimated from } \\
1980-1985\end{array}$} & \multicolumn{3}{|c|}{$\begin{array}{c}\text { Forecasted Growth } \\
1980-1990 \\
\end{array}$} \\
\hline & & & Mn & $\operatorname{Max}$ & Min & $\operatorname{Max}$ & Min & Max & \\
\hline \multicolumn{10}{|l|}{ Mield Supervision/Inspection } \\
\hline $\begin{array}{l}\text { Construction Superintendent } \\
\text { Foreman } \\
\text { Inspectors }\end{array}$ & $\begin{array}{r}2 \\
3 \\
17 \\
22\end{array}$ & $\begin{array}{r}.23 \\
.34 \\
1.92\end{array}$ & $\begin{array}{r}27 \\
40 \\
227 \\
294\end{array}$ & $\begin{array}{r}74 \\
110 \\
621 \\
805\end{array}$ & $\begin{array}{r}85 \\
126 \\
\frac{72}{923}\end{array}$ & $\begin{array}{r}233 \\
345 \\
1948 \\
2526\end{array}$ & $\begin{array}{r}112 \\
166 \\
938 \\
1216\end{array}$ & $\begin{array}{r}308 \\
455 \\
2569 \\
3332\end{array}$ & \\
\hline \multicolumn{10}{|l|}{ Skilled Labor } \\
\hline $\begin{array}{l}\text { Mectrician } \\
\text { Pipefltter } \\
\text { Helder } \\
\text { Mlilwright } \\
\text { Machinist } \\
\text { Ironworker } \\
\text { Rigger } \\
\text { Concrete Worker } \\
\text { Sheetmetal Horker } \\
\text { Carpenter } \\
\text { Plumber } \\
\text { Insulation Installer } \\
\text { T1le Setter } \\
\text { Painter } \\
\text { Crane Operator } \\
\text { Plle Driver } \\
\text { Bollexmaker } \\
\text { Bquipment Operator }\end{array}$ & \begin{tabular}{|r}
27 \\
15 \\
8 \\
8 \\
8 \\
2 \\
16 \\
8 \\
15 \\
6 \\
60 \\
4 \\
4 \\
4 \\
2 \\
4 \\
4 \\
4 \\
4 \\
2 \\
27 \\
270
\end{tabular} & $\begin{array}{l}2.37 \\
1.69 \\
.90 \\
.90 \\
.23 \\
1.81 \\
.90 \\
1.69 \\
.68 \\
6.78 \\
.45 \\
.45 \\
.23 \\
.45 \\
.45 \\
.45 \\
.23 \\
3.05\end{array}$ & $\begin{array}{r}280 \\
200 \\
107 \\
107 \\
27 \\
213 \\
107 \\
200 \\
80 \\
800 \\
53 \\
53 \\
27 \\
53 \\
53 \\
53 \\
27 \\
360 \\
2800\end{array}$ & $\begin{array}{r}766 \\
547 \\
291 \\
291 \\
74 \\
585 \\
291 \\
547 \\
220 \\
2192 \\
146 \\
146 \\
74 \\
146 \\
146 \\
146 \\
74 \\
986 \\
7668\end{array}$ & $\begin{array}{r}879 \\
627 \\
334 \\
334 \\
85 \\
671 \\
334 \\
627 \\
252 \\
254 \\
167 \\
167 \\
85 \\
167 \\
167 \\
167 \\
85 \\
1131 \\
8793\end{array}$ & $\begin{array}{r}2405 \\
1715 \\
913 \\
913 \\
233 \\
1836 \\
913 \\
1715 \\
690 \\
6880 \\
457 \\
457 \\
233 \\
457 \\
457 \\
457 \\
233 \\
3095 \\
24059\end{array}$ & $\begin{array}{r}1158 \\
826 \\
440 \\
440 \\
112 \\
885 \\
440 \\
826 \\
332 \\
3314 \\
220 \\
220 \\
112 \\
220 \\
220 \\
220 \\
112 \\
1491 \\
11588\end{array}$ & $\begin{array}{r}3172 \\
2262 \\
1204 \\
1204 \\
308 \\
2422 \\
1204 \\
2262 \\
910 \\
9073 \\
602 \\
602 \\
308 \\
602 \\
602 \\
602 \\
308 \\
482 \\
28129\end{array}$ & \\
\hline \multicolumn{10}{|l|}{ Others } \\
\hline $\begin{array}{l}\text { Teamster } \\
\text { Toolpusher } \\
\text { Contract Support } \\
\text { Common Iaborer } \\
\text { Drilling Head } \\
\text { Warehouseman }\end{array}$ & $\begin{array}{r}13 \\
2 \\
2 \\
42 \\
1 \\
3\end{array}$ & $\begin{array}{r}1.47 \\
.23 \\
.23 \\
4.75 \\
.11 \\
.34\end{array}$ & $\begin{array}{r}173 \\
27 \\
27 \\
560 \\
13 \\
40 \\
\end{array}$ & $\begin{array}{r}475 \\
74 \\
74 \\
1536 \\
37 \\
110 \\
\end{array}$ & $\begin{array}{r}545 \\
85 \\
85 \\
1761 \\
42 \\
126 \\
\end{array}$ & $\begin{array}{r}1492 \\
233 \\
233 \\
4820 \\
116 \\
345 \\
\end{array}$ & $\begin{array}{r}718 \\
112 \\
112 \\
2322 \\
56 \\
166 \\
\end{array}$ & $\begin{array}{r}1967 \\
308 \\
308 \\
6356 \\
154 \\
455 \\
\end{array}$ & $\ldots$ \\
\hline & $\therefore$ Subtotal 63 & & 840 & 2306 & 2644 & 7239 & 3486 & 9548 & \\
\hline & TOTAL 488 & & 6052 & 16591 & 19022 & 52063 & 25076 & 65070 & \\
\hline
\end{tabular}


TABLE D-6. OPIRRATION AND MaINTENANGE OF PONER PLANT

\begin{tabular}{|c|c|c|c|c|c|c|c|c|c|}
\hline$\ldots$ & \multirow{2}{*}{\multicolumn{2}{|c|}{$\begin{array}{l}\text { Summed Total of Individuals } \\
\text { from Surveyed Firms and } \\
\text { Profect Independence }\end{array}$}} & \multirow{2}{*}{$\begin{array}{l}\text { Forecasting } \\
\text { Coefficient } \\
\text { (percent) }\end{array}$} & \multicolumn{4}{|c|}{$\begin{array}{c}\text { Derived New Employment Estimated from } \\
1980-1985\end{array}$} & \multicolumn{2}{|c|}{$\begin{array}{c}\text { Forecasted Growth } \\
\quad 1980-1990\end{array}$} \\
\hline & & & & Min & $\operatorname{Lax}$ & MLn & $\overline{\operatorname{Max}}$ & Min & Max \\
\hline \multicolumn{10}{|l|}{ Scientist./Engineer } \\
\hline $\begin{array}{l}\text { Mechanical Engineer } \\
\text { Corrosion Ingineer }\end{array}$ & Subtotal & $\frac{1}{2}$ & .11 & $\begin{array}{l}13 \\
\frac{13}{26}\end{array}$ & $\begin{array}{l}37 \\
37 \\
74\end{array}$ & $\begin{array}{l}42 \\
42 \\
84\end{array}$ & $\frac{116}{116}$ & $\begin{array}{r}56 \\
56 \\
112\end{array}$ & $\begin{array}{l}154 \\
154 \\
308\end{array}$ \\
\hline \multicolumn{10}{|l|}{ Technictans } \\
\hline $\begin{array}{l}\text { Senfor Power Plant Operator } \\
\text { Power Plant Operator } \\
\text { Asst. Power Plant Operator } \\
\text { Control Technician } \\
\text { Instrument Techniclan }\end{array}$ & Subtotal & $\begin{array}{r}2 \\
21 \\
4 \\
\frac{6}{34}\end{array}$ & $\begin{array}{r}.23 \\
2.37 \\
.45 \\
.11 \\
.68\end{array}$ & $\begin{array}{r}27 \\
280 \\
53 \\
13 \\
80 \\
453\end{array}$ & $\begin{array}{r}74 \\
766 \\
146 \\
37 \\
220 \\
1243\end{array}$ & $\begin{array}{r}85 \\
879 \\
167 \\
42 \\
252 \\
1425\end{array}$ & $\begin{array}{r}233 \\
2405 \\
457 \\
116 \\
690 \\
3901\end{array}$ & $\begin{array}{r}112 \\
1158 \\
220 \\
56 \\
332 \\
1878\end{array}$ & $\begin{array}{r}308 \\
3172 \\
602 \\
154 \\
910 \\
5146\end{array}$ \\
\hline \multicolumn{10}{|l|}{ Supervi sory Personnel } \\
\hline $\begin{array}{l}\text { Plant Superintendent } \\
\text { Shift. Foreman } \\
\text { Foreman }\end{array}$ & Subtotal & $\begin{array}{l}1 \\
3 \\
2 \\
6\end{array}$ & $\begin{array}{l}.17 \\
.34 \\
.23\end{array}$ & $\begin{array}{l}13 \\
40 \\
27 \\
80\end{array}$ & $\begin{array}{r}37 \\
110 \\
74 \\
221\end{array}$ & $\begin{array}{r}42 \\
126 \\
85 \\
253\end{array}$ & $\begin{array}{l}116 \\
345 \\
233 \\
694\end{array}$ & $\begin{array}{l}\frac{56}{166} \\
112 \\
334\end{array}$ & $\begin{array}{l}154 \\
455 \\
308 \\
917\end{array}$ \\
\hline \multicolumn{10}{|l|}{ Skdiled Labor } \\
\hline $\begin{array}{l}\text { Millwright } \\
\text { Machinist } \\
\text { Plpefltter } \\
\text { Welder } \\
\text { Electrician } \\
\text { Insulation Installer } \\
\text { Painter } \\
\text { Rigger } \\
\text { Grane Operator }\end{array}$ & . & $\begin{array}{r}4 \\
13 \\
3 \\
4 \\
11 \\
2 \\
2 \\
5 \\
\frac{1}{45}\end{array}$ & $\begin{array}{r}.45 \\
1.47 \\
.34 \\
.45 \\
1.24 \\
.23 \\
.23 \\
.56 \\
.11\end{array}$ & $\begin{array}{r}53 \\
173 \\
40 \\
53 \\
147 \\
27 \\
27 \\
67 \\
13 \\
-600\end{array}$ & $\begin{array}{r}146 \\
475 \\
110 \\
146 \\
401 \\
74 \\
74 \\
181 \\
37 \\
1644\end{array}$ & $\begin{array}{r}167 \\
545 \\
126 \\
167 \\
460 \\
85 \\
85 \\
208 \\
42 \\
\frac{48}{1885}\end{array}$ & $\begin{array}{r}457 \\
1492 \\
345 \\
457 \\
1258 \\
233 \\
233 \\
568 \\
116 \\
5159\end{array}$ & $\begin{array}{r}220 \\
718 \\
166 \\
220 \\
606 \\
112 \\
112 \\
274 \\
56 \\
2484\end{array}$ & $\begin{array}{r}602 \\
1967 \\
455 \\
602 \\
1659 \\
308 \\
308 \\
749 \\
154 \\
6804\end{array}$ \\
\hline \multirow[t]{2}{*}{$\frac{\text { Other }}{\text { Laborer }}$} & Subtotal & 6 & & $\cdots$ & 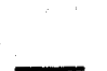 & & & & \\
\hline & TOTAL & 93 & 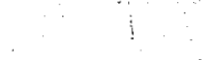 & 1159 & 3182 & 3647 & 9986 & 4808 & 13175 \\
\hline
\end{tabular}

